GEOLOGICAL SURVEY CIRCULAR 366

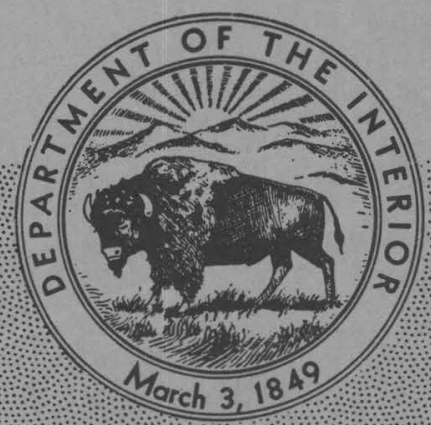

WATER RESOURCES OF THE

INDIANAPOLIS AREA

INDIANA 

UNITED STATES DEPARTMENT OF THE INTERIOR

Douglas McKay, Secretary

GEOLOGICAL SURVEY

W. E. Wrather, Director

GEOLOGICAL SURVEY CIRCULAR 366

\section{WATER RESOURCES OF THE INDIANAPOLIS AREA, INDIANA}

By C. M. Roberts, L. E. Widman, and P. N. Brown 



\section{PREFACE}

This report is one of a series concerning water resources and present water use in selected industrial areas of national importance, which has been prepared at the request of and in consultation with the Water and Sewerage Industry and Utilities Division of the Business and Defense Services Administration of the U. S. Department of Commerce. This series is designed to serve the dual purpose of providing information for national defense planning and at the same time render a valuable service to business and industry in their development of water resources for present and future use. This report was prepared with the assistance of J. B. Graham and K. A. MacKichan of the Water Utilization Section, Technical Coordination Branch. It was prepared by C. M. Roberts, district geologist (Ground Water Branch); L. E. Widman, under the supervision of D. M. Corbett, district engineer (Surface Water Branch); and P. N. Brown, under the supervision of W. L. Lamar, district chemist (Quality of Water Branch).
Many of the data used in this report were collected over a period of years by the U. S. Geological Survey in cooperation with the Indiana Department of Conservation, the Indiana Flood Control and Water Resources Commission, State Board of Health, and the State Highway Commission.

Information on the industrial use of surface water was obtained from the Indianapolis Power and Light Co. and the Indianapolis Water Co.

Officials of all public water supply organizations cooperated by providing detailed information on water supply within their service areas. Special thanks go to individuals who cooperated in furnishing water samples for analysis and to H. E. Abbott, Marion County Agricultural Agent, for data on irigation and farm use of water. 


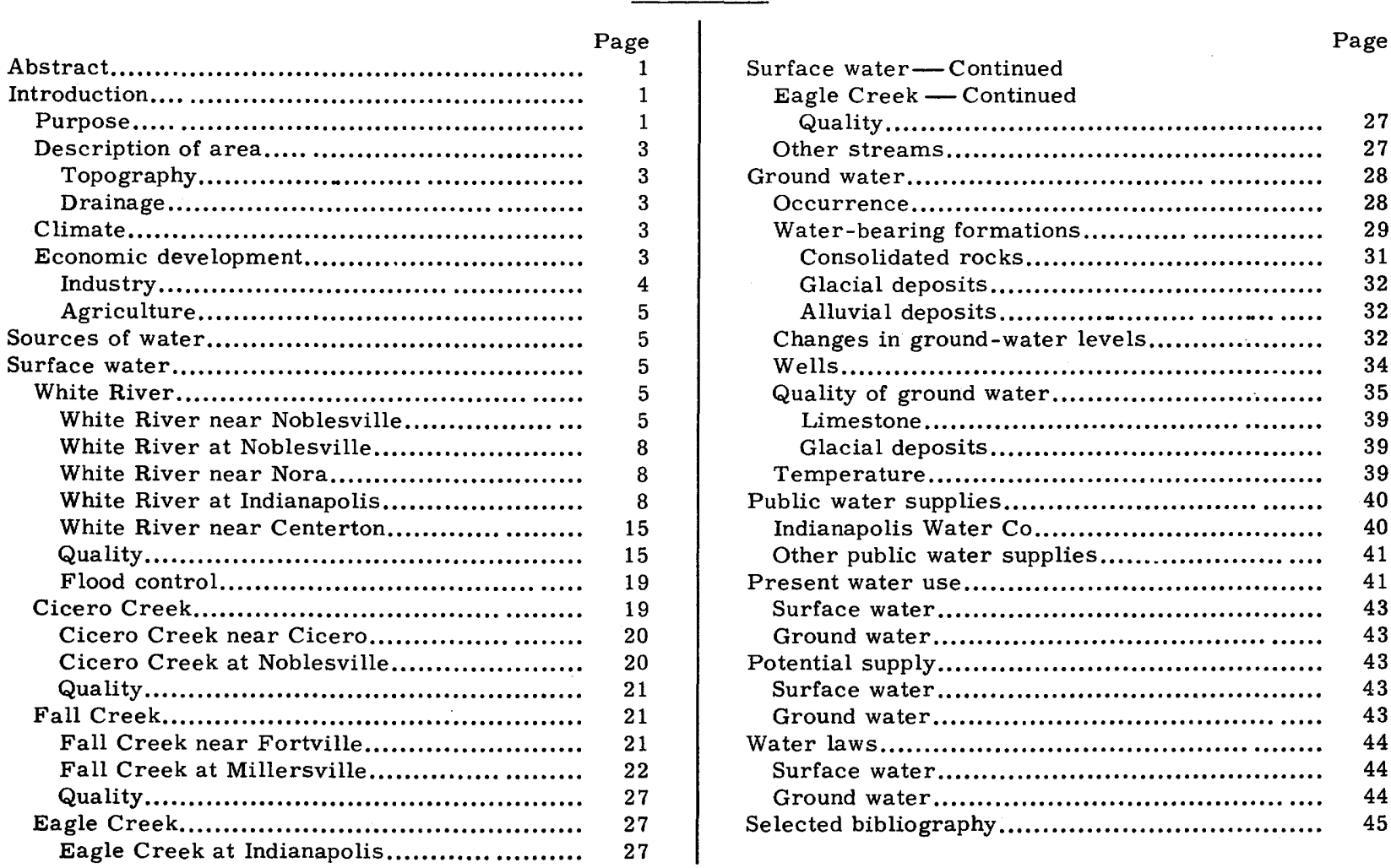

\section{ILLUSTRATIONS}

Plate 1. Map of the upper White River basin showing stream gaging stations and quality-of-water sampling sites.

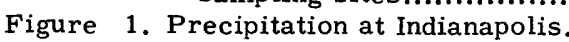

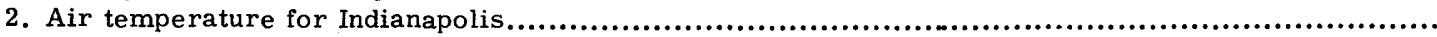

3. Population of Indianapolis and Marion County, 1830-1950

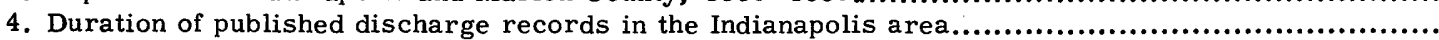

5. Duration curve of daily flow, White River near Noblesville and White River at Noblesville............

6. Duration curve of daily flow, White River near Nora...

7. Discharge available without storage, White River near Nora, $1931-51$.

8. Low-flow frequency curves, White River near Nora, 1931-51

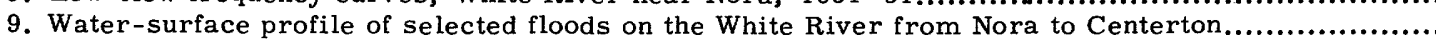

10. Flood-stage frequencies, White River near Nora, 1931-51

11. Duration curve of daily flow, White River at Indianapolis and White River near Centerton, $1931-51$

12. Month of occurrence of highest annual stage, White River at Indianapolis.................................

13. Flood-stage frequencies, White River at Indianapolis, 1931-51

14. Composition of selected surface waters.

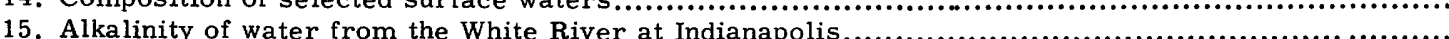

16. Cumulative frequency curve of temperature, White River at Indianapolis, $1947-51 \ldots \ldots \ldots \ldots \ldots \ldots \ldots$

17. Duration curve of daily flow, Cicero Creek.

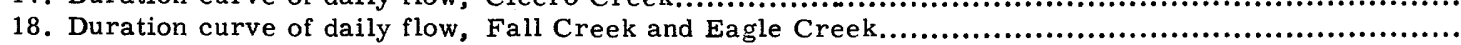

19. Storage requirements, Fall Creek near Fortville and Eagle Creek at Indianapolis.......................

20. Duration curve of daily flow, Fall Creek at Millersville...................................................

21. Flood-stage frequencies, Fall Creek at Millersville, $1931-51$. 


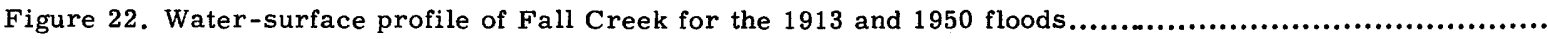

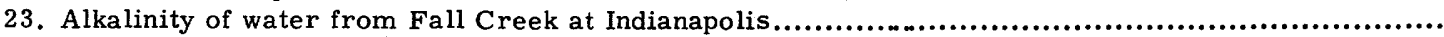

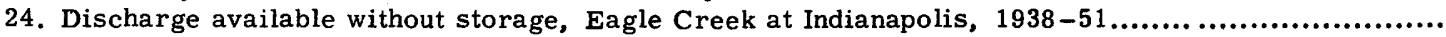

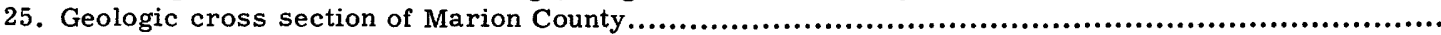

26. Hydrograph of a typical well.

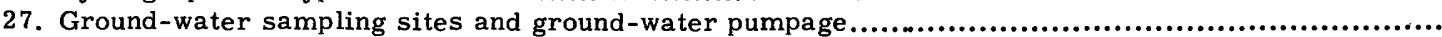

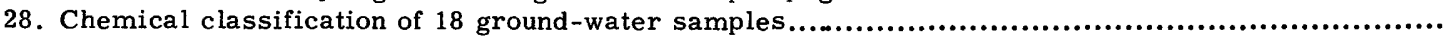

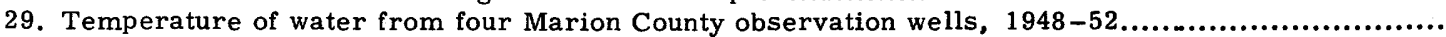

\section{TABLES}

Table 1. Selected major floods on the White River, Fall Creek, and Eagle Creek...................................

2. Chemical analyses of water from selected streams.

3. Composition of dissolved solids in water from selected streams .........................................

4. Chemical analyses of selected ground-water samples.

5. Composition of dissolved solids in selected ground water ....................................................

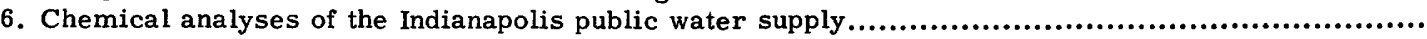

7. Public water supply systems, 1952 .

8. Average daily pumpage of ground water 


\title{
WATER RESOURCES OF THE INDIANAPOLIS AREA, INDIANA
}

\author{
By C. M. Roberts, L. E. Widman, and P. N. Brown
}

\begin{abstract}
Water used in the Indianapolis area comes from two sources: the White River and tributary streams and the underground reservoirs formed by the underlying glacial drift and limestone. Surface-water sources provide about $60 \mathrm{mgd}$ (million gallons per day) for public supply. and an additional $300 \mathrm{mgd}$ is used by private industries and is returned directly to the streams. About $60 \mathrm{mgd}$ is taken from ground-water sources by public water supplies and industries. The total use of water, therefore, is about $420 \mathrm{mgd}$.

The city of Indianapolis and several adjacent urban communities are supplied through the surface-water sources by a private water company, the Indianapolis Water Co. Water is impounded in the Geist Reservoir on Fall Creek. At Broad Ripple, on White River, a low dam is used to divert river water into a feeder canal to a treatment plant. Expansion of the present facilities of this company is in progress. A new reservoir with a capacity about equal to that of Geist Reservoir is being constructed on Cicero Creek, a tributary of the White River. These combined river sources will provide an abundant supply of good water in excess of present demands. This will permit expansion of surface-water use for public, commercial, and industrial supply in the service area of this water company.
\end{abstract}

Industry is the heaviest user of ground water in the area. Of the $56 \mathrm{mgd}$ of ground water pumped in 1952 about 70 percent was used by industry. Agriculture was next with a pumpage of about 15 percent and the remainder or 15 percent was for public and private water supply. The ground water is of relatively uniform composition and temperature.

Difficulties in supplying water have occurred and will continue to occur from time to time when demands on ground-water sources are excessively heavy for long periods of time and locally where pumped wells are too closely spaced. Under such conditions ground-water levels decline rapidly and remain depressed for some time. Such a condition may constitute what could be called a water shortage.

As the demand for water increases there is need for conservation and wise use of available surfaceand ground-water supplies.

\section{INTRODUCTION}

The economic and industrial progress of a metropolitan area is dependent on the existence and availability of a supply of water. All sources capable of yielding water of suitable quality in sufficient quantities to fulfill any long term demands must be carefully evaluated to assure wise use and insure the industrial growth of the area.

The Indianapolis metropolitan area is still expanding in many directions. The early growth of Indianapolis was based on the development and use of shallow groundwater sources. Continued growth was attended by unrestrained development of ground water. Since the latter part of 1904 , river sources have been developed gradually and today are the chief sources of public water supply. Water for industrial uses within the city and for industrial, public, and private uses elsewhere is obtained from wells and surface sources.

The present trend of living in the suburbs has created a demand for water outside the city limits but unlike previous periods of growth this trend is coupled with a greater per capita use of water. Similarly, industrial growth within the Indianapolis area has not been confined to any one locality or to a specific section within the present city limits. Many of the new industrial plants, both large and small, have been built or are being planned for areas where there is less congestion, plenty of available land, and ready access to transportation facilities. Water is essential to every plant for drinking and sanitary uses and in many plants is required for use directly or indirectly in the production of goods and manufactured articles.

\section{$\underline{\text { Purpose }}$}

This report summarizes the available streamflow data in the Indianapolis area and evaluates the groundwater resources insofar as information is available.

The report will not resolve all questions that relate to water supplies for municipal and industrial development in any specific location. The many factors involved will always call for detailed investigations. However, it will give valuable data on water resources that should guide industries in their initial plans for new works or expansion of existing facilities. It also 

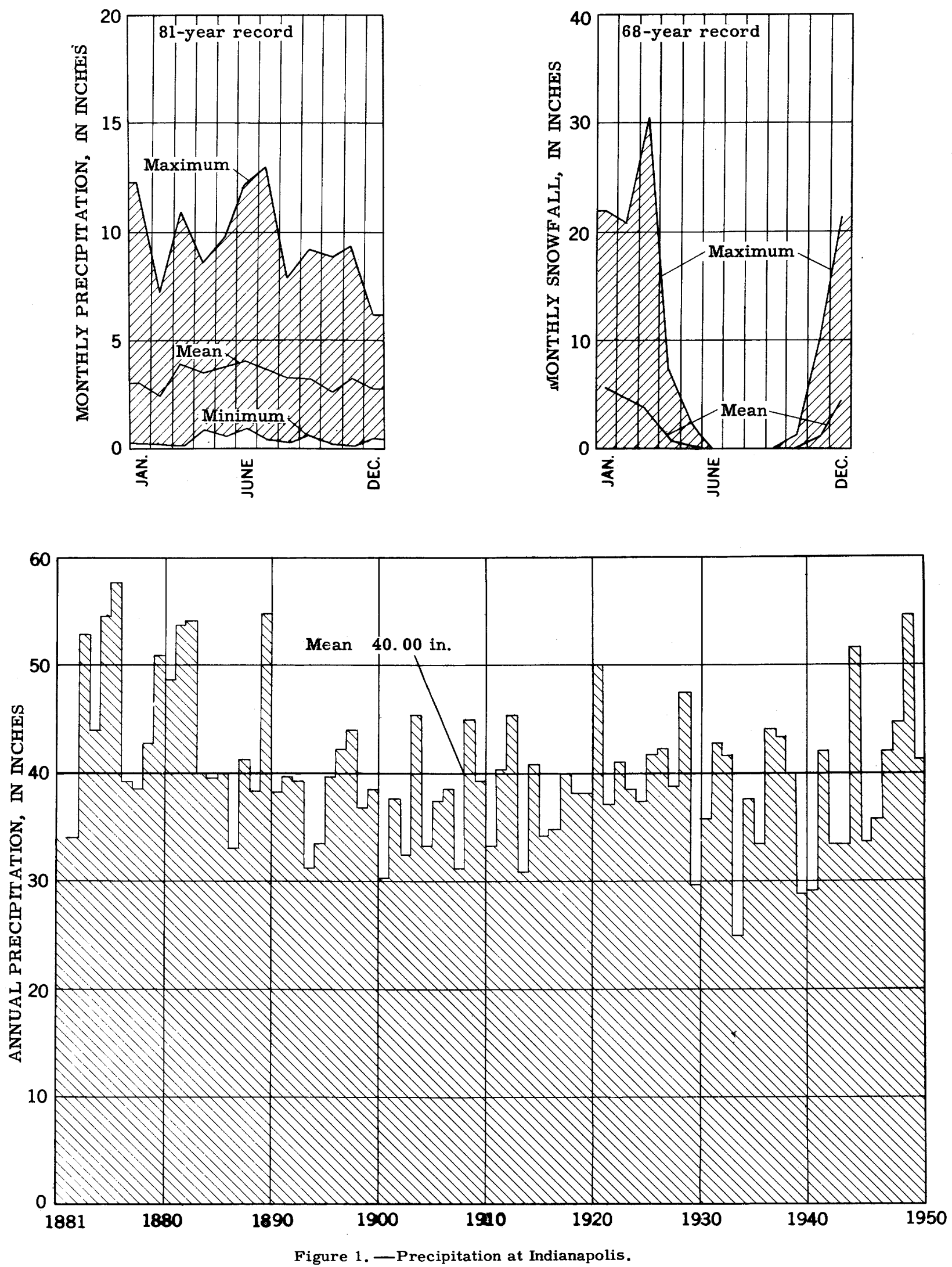
contains data which will be useful to State and local groups in planning for orderly growth of the area.

\section{Description of Area}

Indianapolis area as used in this report is defined as coextensive with Marion County (pl. 1). Marion County has an area of about 400 square miles and is the central county of Indiana. Indianapolis is the capital and largest city in Indiana and is also the county seat of Marion County.

\section{Topography}

The area considered in this report is a part of the physiographic area known as the Tipton till plain, an area underlain by a substantial thickness of glacial drift. In the vicinity of Indianapolis this plain is a broad undulating surface of low hills and hollows, skirted by low ridges. In some places fairly steepsided valleys have been cut into the plain. Irregular morainic belts cross the area from northwest to southeast or north to south, and broad sediment-filled valleys cross the county from northeast to southwest.

The surface forms observed in Marion County and adjacent counties are evidence of former glaciation. During the glacial epoch the bedrock of the area was divested of its cover or overburden of soil and weathered rock by successive ice sheets advancing from the north. The ice deepened existing valleys and carved new valleys where soft and weak rock zones were present. Successive periods of advance and retreat of the ice front in this area left a heterogeneous unconsolidated glacial drift that ranges in thickness from about 25 feet to 325 feet or so.

\section{Drainage}

The Indianapolis area lies in the drainage basin of the White River (pl. 1). The headwaters are north and northeast of Indianapolis and are characterized by many springs. Water stored in the underground res ervoirs is slowly discharged by these springs during periods of little or no precipitation.

The White River enters Marion County from the northeast and flows southwestward. In the vicinity of Broad Ripple it flows between low, irregularly shaped ridges of glacial drift. In Indianapolis, just below the mouth of a small tributary, Williams Creek, the river is diverted to the west side of a wide valley that is underlain by glacial drift to a considerable depth. Along the western side of the city, the river has cut a deep gorge into the drift.

Fall Creek, an important tributary of the White River, enters the city from an easterly direction. Between Fort Benjamin Harrison and the city limits Fall Creek occupies an old valley now filled with sediment. As it approaches the river, this valley widens out and blends into the terraces along the east bank of the White River upon which the original and main part of Indianapolis is built.
Eagle Creek is the only major tributary entering the White River from the west in Marion County. This stream, in its upper section, has cut a valley to a nearly level or gently rolling upland. The lower section of the stream cuts across glacial outwash deposits and alluvium. A well developed flood plain extends as far upstream as Zionsville just north of the county line.

Small streams such as Pogues Run, which is carried through downtown Indianapolis in a covered drain, Pleasant Run, Lick Creek, and Little Buck Creek originate or a nearly level upland east of the river and cut across the terrace along the east bank of the White River before entering the river.

In the southeastern part of Marion County a low surface divide separates the drainage of the White River from that of East Fork White River. Buck Creek, a tributary of East Fork White River, flows across an upland plain of low hills and shallow valleys.

\section{Climate}

The Indianapolis area is in the eastern part of the central interior region of the United States. Its climate is of the continental type, derived from air masses that travel considerable distances over the land. Warm moisture-laden air masses move from the Gulf of Mexico up the Mississippi Valley into the Ohio Valley and thence eastward, and cold, dry air masses from the far west cross the plains of this interior region from west to east. Combinations of these two air masses are mainly responsible for variations in weather with an occasional long period of extremely hot or extremely cold weather.

Indianapolis has a temperate climate, warm summers, moderately cold winters, and precipitation that is well distributed throughout the year (figs. 1 and 2). The annual air temperature varies only slightly from year to year and averages $53^{\circ} \mathrm{F}$. The average annual precipitation is 40.0 inches. The growing season or frost-free period is from about April 16 to about October 21 . Winters are moderately cold with inf requent sudden changes and severe cold periods. Precipitation during the winter averages about 3 inches, including about 5 inches of snowfall per month. Sultry weather, but not extreme heat, and humidity characterize the months of June, July, and August. From 3 to 4 inches of rainfall a month is about normal during this season. Average wind velocity is about 10 miles per hour. Dominant wind directions are south and southwest.

\section{Economic Development}

The population of Marion County in 1950 was 551, 771 and the city of Indianapolis had a population of 427,173 . During the period $1940-50$, the county population increased by about 20 percent and the city population by about 10 percent. The population of the city and county at each census from 1830 to 1950 is shown in figure 3 . 


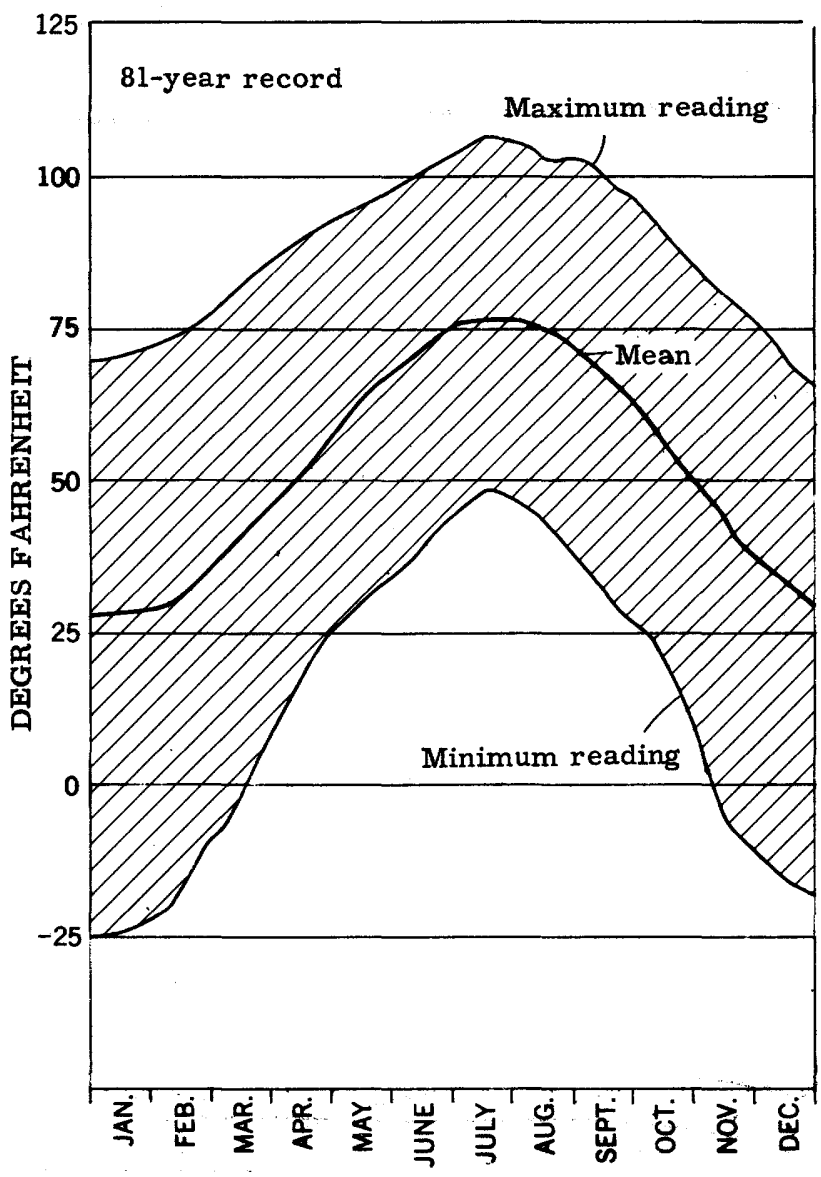

Figure 2. - Air temperature for Indianapolis. Industry

Industrial growth and development is similar to that in other fast growing cities undergoing transition into a metropolitan area. The trend in recent years is for industry to locate outside of the densely populated and highly commercialized sections of the city. Consequently, one finds centers of industrialization scattered throughout the entire area. This expansion has been attended by problems of water supply. Users of water have developed supplies with little or no information of proven conditions as to available sources, quality of the water, and adequacy of the supply. In some places public and private water companies have expanded their own facilities to supply industry with additional quantities of water.

Diversity of manufacturing and commercial enterprise usually gives rise to variations in water requirements. Of the 3,600 industrial and commercial establishments now in the area, about 650 are devoted to manufacture. These plants, collectively and some individually, are large users of water.

In the early days of industrial growth, ground-water sources provided the water for industry. Large quantities of water were obtained from wells drilled into the water-bearing zones of the underlying limestone bedrock and glacial drift. Most commercial establishments and some industries have abandoned the

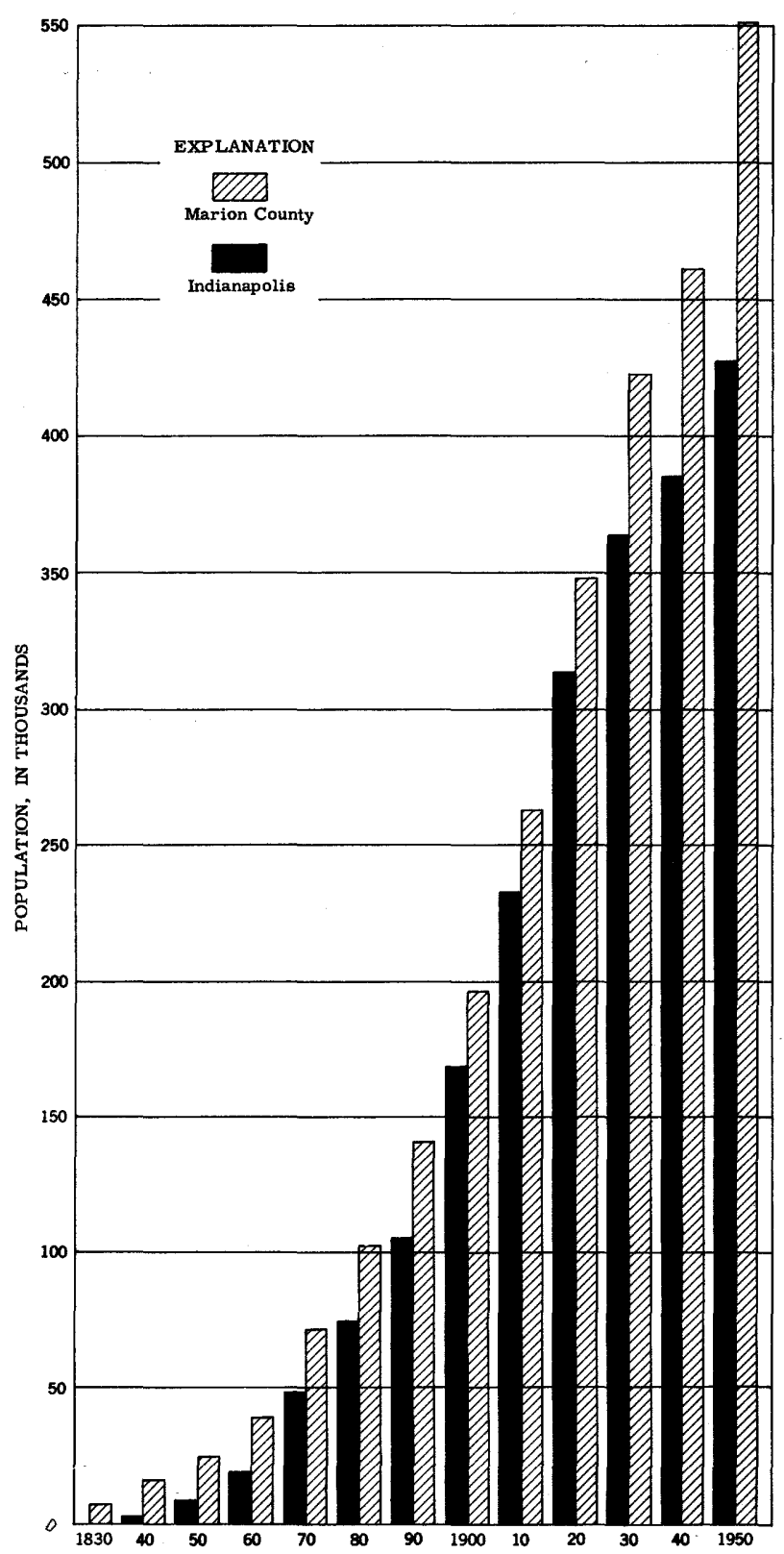

Figure 3. - Population of Indianapolis and Marion County, $1830-1950$.

use of wells in favor of water from other sources, particularly the public water supply. The largest number of such conversions have been in water for drinking and sanitary uses, for small air-conditioning units, and for some manufacturing. Several additional large industries have found it economical to purchase part of their water supply from local public suppliers during certain months of the year. Other industries continue to rely on wells for their entire supply of water. Some of them periodically rehabilitate their wells, others abandon old worn-out wells and drill new ones to replace old wells or to augment those in use. 


\section{Agriculture}

Indianapolis is in the very heart of an agricultural area. Produce grown within Marion County is readily marketable in Indianapolis. Because produce farmers do not have to truck long distances to a seller's market, certain kinds of farming are profitable; this has kept more land area in good farms than is usual in a metropolitan area. Seventy-one percent of a total area of about 254, 000 acres in Marion County is still in agriculture. There are about 4,300 farms in the county; of the 2, 300 classified as full-time farms, about 300 are vegetable farms and the remainder are dairy farms. There are about 2,000 subsistence farms. Of the total acreage in farms 12,500 acres is subject to overflow by the White River and is not generally cultivated. About one-third of the 300 vegetable farms in the county practice irrigation to some extent, mainly from wells. More acreage is irrigated each year owing to low costs of irrigation systems and the prospects of high returns on the investment.

The most productive farms are in the valley of the White River, on the terraces and those parts of the bottom land that are not readily flooded. Large, less productive farms are scattered throughout the upland areas. Ponds are quite common on these farms where the soil is clayey and tight. These ponds average about three-fourths of an acre in size and are used mainly for watering livestock and for fire protection. Water generally is fed into these ponds from streams. In regions where streamflow is not always perennial, the ponds are periodically replenished with water from the ground-water sources, if a supply is available.

\section{SOURCES OF WATER}

Water suitable for use is obtained from streams, lakes, reservoirs, springs, and wells. However, the principal sources of water are the White River and its tributaries and wells that obtain water from the glacial drift and bedrock.

During rainstorms, water falling in excess of that which the ground is able to absorb flows over the ground into the streams. The water that percolates into the ground replenishes the shallow zone of soil water that supports vegetation; the water not held in this zone continues to move by gravity to the zone of saturation, the upper surface of which is the water table. The water in the zone of saturation slowly moves by gravity through the ground in directions determined by the topography and geologic structure. Ground-water discharge may occur naturally as from springs and seeps to become part of the flow of streams, and by evaporation and transpiration where the water table lies near the land surface. About onethird of the precipitation may be expected to replenish the surface and ground sources; the remainder returns to the atmosphere.

\section{SURFACE WATER}

The White River and two of its larger tributaries, Fall Creek and Eagle Creek, flow through Indianapolis. Both the main stream and Fall Creek are major sources of surface-water supply for the area. Cicero Creek, which enters the White River at Noblesville, about 20 miles north of Indianapolis, is also an important source of water for Indianapolis. These streams are good sources of water because the variation of flow is moderate.

Records of streamflow have been collected at several sites in the Indianapolis area (fig. 4). Although the records are of relatively short duration, those records for the period 1929-51 include both wet and dry periods and therefore should be a good index of the streamflow characteristics. In general, the streamflow data in this report includes data through the water year 1951 (year ending Sept. 30, 1951). Data for more recent years were not available when that part of this report was prepared. However, the minimum flow for the water years 1952 and 1953 have been given if they were less than the previously recorded minimum. Exceptionally low flow was prevalent at the end of the 1953 water year; therefore it is possible that flows lower than those given have been recorded since Sept. 30 , 1953 .

Surface waters in general undergo frequent and wide variations in the amount of solids dissolved in the water. Strict characterization of a surface water as to chemical quality requires extensive regular sampling and analysis. Analyses of relatively few samples are given in table 2 and figure 14 . These samples define the chemical character of the water at the time of sampling, but should not be interpreted as giving the detailed character of the water that would be available at any other time.

\section{White River}

The White River rises below Winchester in Randolph County, Ind., near the Indiana-Ohio boundary and flows westward about 60 miles to the center of the State (pl. 1). Here the river turns southward and flows through Indianapolis to southwestern Indiana, where it is joined by East Fork White River. Fifty-two miles below the mouth of the East Fork, the White River enters the Wabash River, a major tributary of the Ohio River and the southwestern boundary of Indiana.

The White River drains an area of 11,400 square miles that has two general types of topography. The upper area, drained by the White River above Indianapolis, is a relatively flat or gently rolling till plain. The lower White River and East Fork White River drain areas of more rugged topography. The topography of a drainage basin influences streamflow characteristics. The streams in the basin above Indianapolis have less variation in flow than those in the drainage basins of lower White River and East Fork White River.

\section{White River near Noblesville}

Streamflow records have been collected since 1915 at a point 7 miles northeast of Noblesville and 2 miles above Clare. The drainage area at this point is 819 square miles. The average discharge for 32 years (water years $1916-25,1930-51)$ is $524 \mathrm{mgd}(810 \mathrm{cfs}$ ). The minimum discharge during water years 1916-25, $1930-53,23 \mathrm{mgd}$ (36 cfs), occurred September 25, 1941 . 


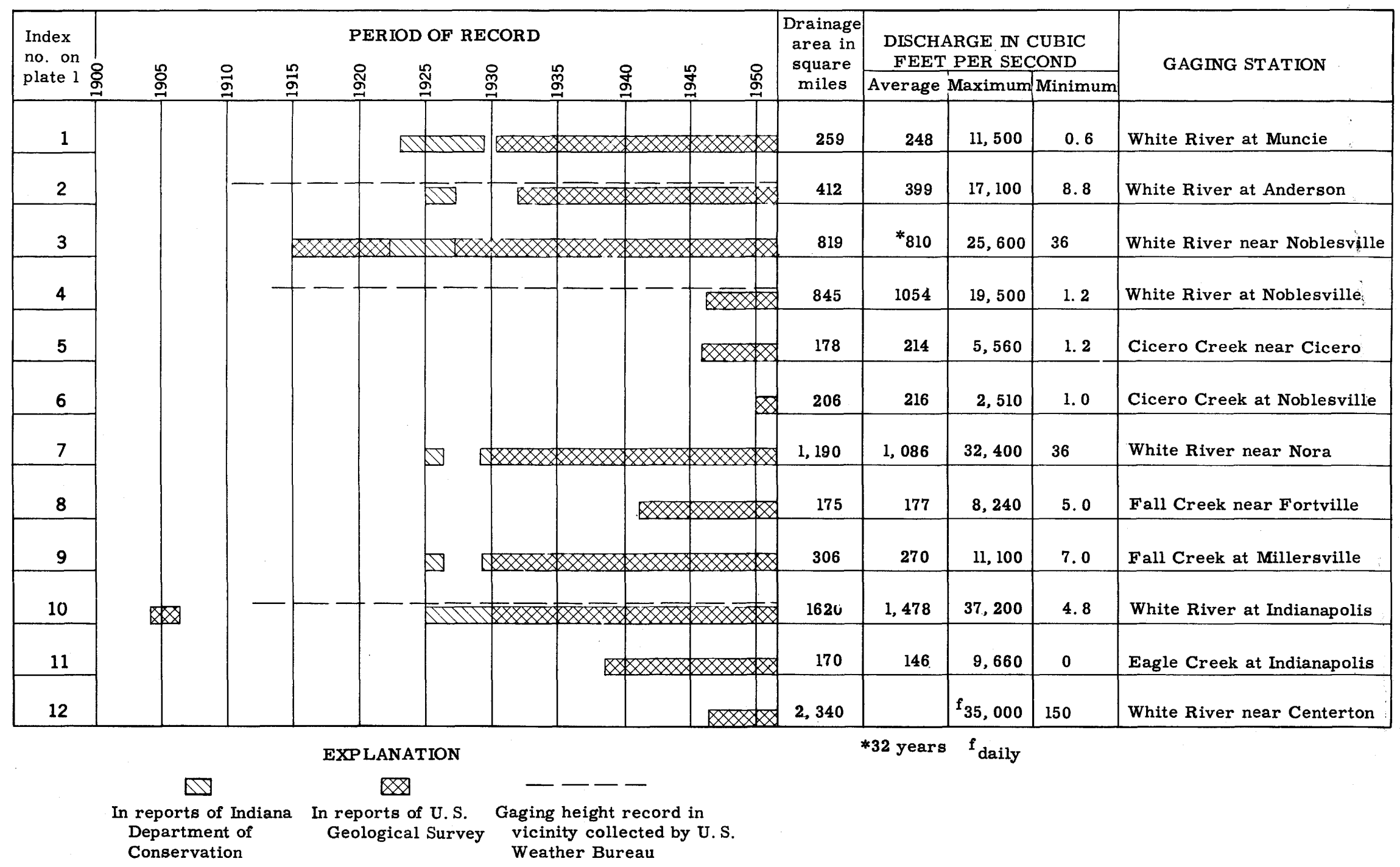




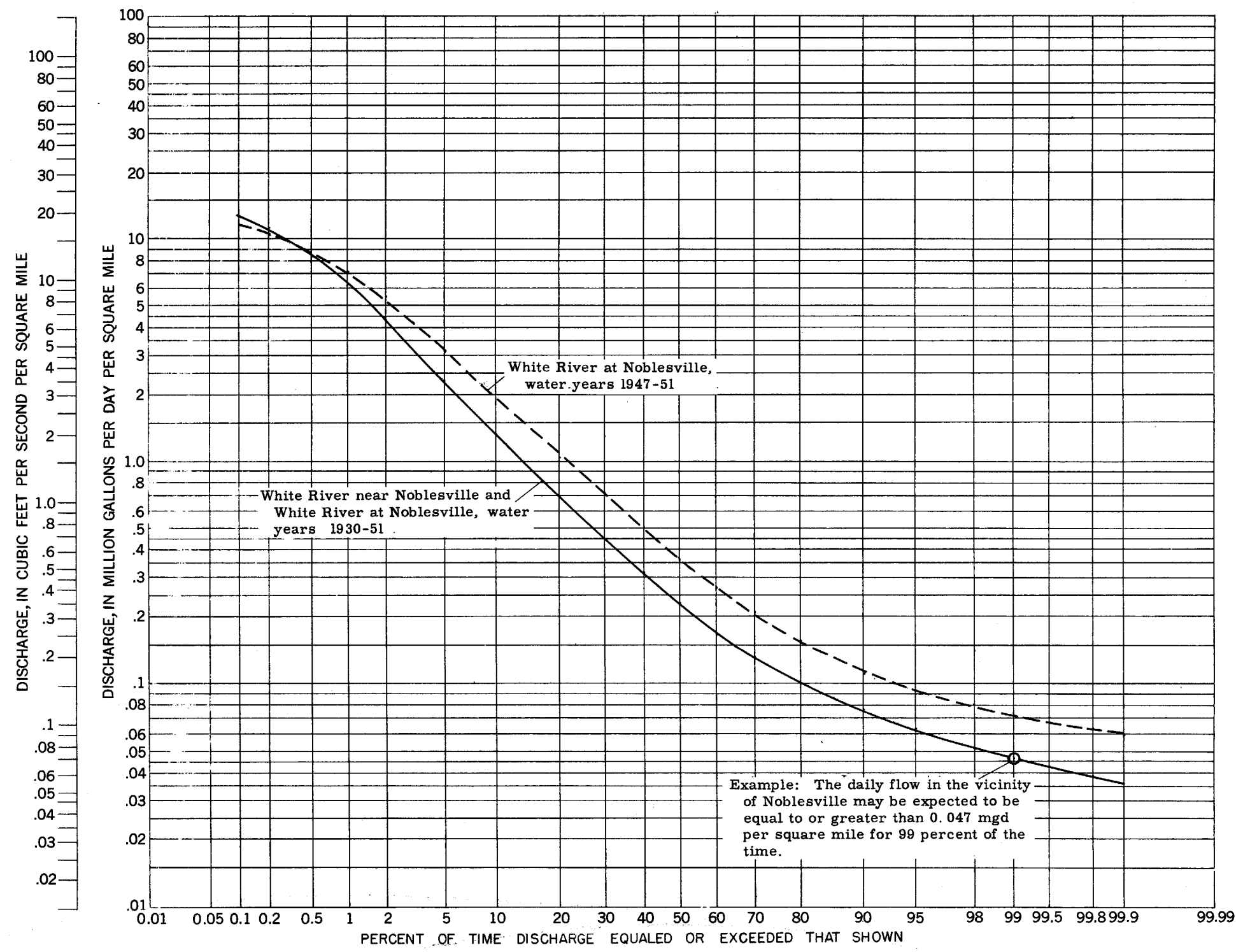

Figure 5. - Duration curve of daily flow, White River near Noblesville and White River at Noblesville. 
The flow characteristics of the stream are shown by a flow-duration curve (fig. 5). This flow-duration curve shows the percent of time during which a specified daily discharge has been equaled or exceeded during water years 1930-51. For example, if the period of record is a representative sample of streamflow over the years the daily flow may be expected to be greater than $0.047 \mathrm{mgd}$ per square mile of drainage area for 99 percent of the time. This curve is typical for this reach of the White River and therefore can be used to determine the probable flow at nearby points. To illustrate, upstream from the gaging station at a point that drains an area of 800 square miles, the daily flow may be expected to be greater than 800 times 0.047 , or $37.6 \mathrm{mgd}$, for 99 percent of the time. On the average the flow would be less than $37.6 \mathrm{mgd} 1$ percent of the time or about 4 days per year $(0.01 \mathrm{x}$ $365)$. The slope of the flow-duration curve indicates only moderate variability in flow, as a result of sustaining flow from ground-water storage.

\section{White River at Noblesville}

There is a gaging station on the White River at Noblesville, $1 \frac{1}{2}$ miles upstream from Cicero Creek and 20 miles north of Indianapolis. Here the White River drains an area of 845 square miles. The average discharge for the 5 water years $1947-51$ is 681 mgd $(1,054 \mathrm{cfs})$. The minimum discharge during the water years $1947-53,0.78 \mathrm{mgd}(1.2 \mathrm{cfs})$, occurred September 17, 1949, as the result of some regulation by the powerplant at Clare; the minimum daily discharge, 37.5 (58 cfs), also occurred the same day.

The flow characteristics are shown by a flowduration curve (fig. 5). Two curves are shown: one is for water years 1947-51 and the other is a computed curve for the flow that occurred water years 1930-51. Water years 1947-51 were relatively wet as compared to water years $1930-51$, therefore, the curve using the 1947-51 records plots above the curve for the period 1930-51. The period 1930-51 contained both wet and dry years and is considered to be more representative than the period 1947-51. Therefore, the curve for the period 1930-51 should be used in computing the water supply available from the White River. Short records may be collected during periods of above average or below average discharge and the flow characteristics as defined by these short records may be considerably in error. Figure 5 illustrates the magnitude of the error that may be induced if streamflow records for short periods are used on the assumption that the period was one of normal discharge. If the short period was not one of normal flow the short records should be adjusted so that they represent the flow for a normal period or for some uses they should be adjusted to represent the flow condition for a dry period.

\section{White River near Nora}

At the northern limit of Indianapolis near the village of Nora the White River drains an area of 1,190 square miles. A gaging station was established in 1925 to record the flow as it enters the city and before there is any diversion. The average flow for water years
1926, 1931-51 is $702 \mathrm{mgd}(1,086 \mathrm{cfs})$. The Indianapolis Water Company diverts water for municipal supply at Broad Ripple, $4 \frac{1}{2}$ miles downstream from the gaging station. During some periods of low and medium flow, backwater from the dam at Broad Ripple extends to the vicinity of the gage. At times during low flow, there is slight diurnal regulation by the powerplant at Clare. The minimum discharge during water years 1926 , $1931-53,23 \mathrm{mgd}$ (36 cfs), occurred September 10, 1936 .

The flow characteristics of the stream are shown by the flow-duration curve (fig. 6) which has characteristics similar to those observed for the White River near Noblesville. Low-flow characteristics are also shown by the curves of discharge available without storage (fig. 7) and the low-flow frequency graphs (fig. 8). These curves can be very useful in the solution of many design problems. For example, suppose a flow of $60 \mathrm{mgd}$ ( $93 \mathrm{cfs}$ ) was required for a water supply. This quantity of water would be available from the White River near Nora for 97 percent of the time (fig. 6). During unusually dry years, the daily flow at Nora may be expected to be less than $60 \mathrm{mgd}$ for not more than 48 consecutive days and the average flow for any $3 \frac{1}{2}$-month period may be expected to be not less than $60 \mathrm{mgd}$ (fig. 7). The daily flow will be $60 \mathrm{mgd}$ or less at average intervals of 2.4 years and the average flow for 7 days will be $60 \mathrm{mgd}$ or less at average intervals of 3.2 years. This does not mean that a daily flow of $60 \mathrm{mgd}$ or less will occur at regular intervals of 2.4 years but that over a long period of time the flow will recede to $60 \mathrm{mgd}$ about 42 times in 100 years.

High banks protect most of the Indianapolis area; however, during high-water periods the White River spreads out over the adjacent low fields, and some damage is inflicted on dwellings in the area. To permit using the low areas to the fullest extent, levees have been built to keep out the floodwaters. According to floodmarks surveyed by the Indiana State Highway Commission the flood of March 1913 reached an elevation of 733. 3 feet above mean sea level at the Nora gage site on State Road 100. The designs of many hydraulic structures in the Indianapolis area have been based on this flood. Discharge and flood stage for other recent floods are shown in table 1 . The water-surface profile from the Nora gage through Indianapolis to Centerton for recent major floods is shown in figure 9 . Figure 10 shows the average recurrence interval for flood stages at Nora as they would occur under presentday channel and levee conditions. The flood of 1950 has a recurrence interval of about $5 \frac{1}{2}$ years, or it would occur about 18 times in 100 years.

\section{White River at Indianapolis}

In the southwestern part of Indianapolis at Morris Street and $2 \frac{1}{2}$ miles downstream from the mouth of Fall Creek the White River drains an area of 1,620 square miles. The average discharge for 25 years (water years $1926,1928-51)$ is $955 \mathrm{mgd}(1,478 \mathrm{cfs})$. The minimum discharge during the period 1925-53, $3.1 \mathrm{mgd}$ (4.8 cfs), occurred September 21, 1941. Diversion by the Indianapolis Water Co. for municipal supply from both the White River and Fall Creek considerably affects low flows. Most of the diverted water 


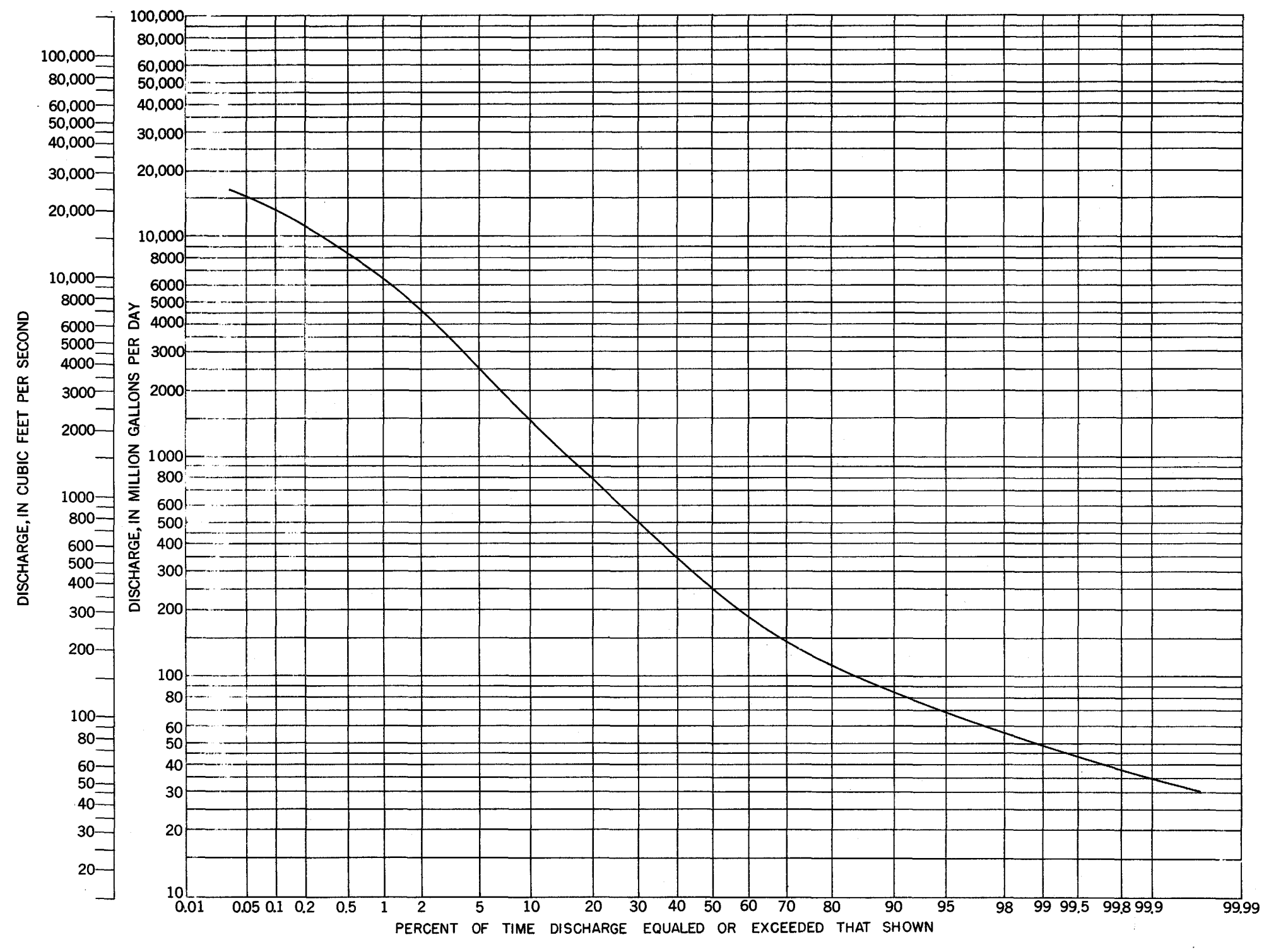

Figure 6. -Duration curve of daily flow, White River near Nora. 


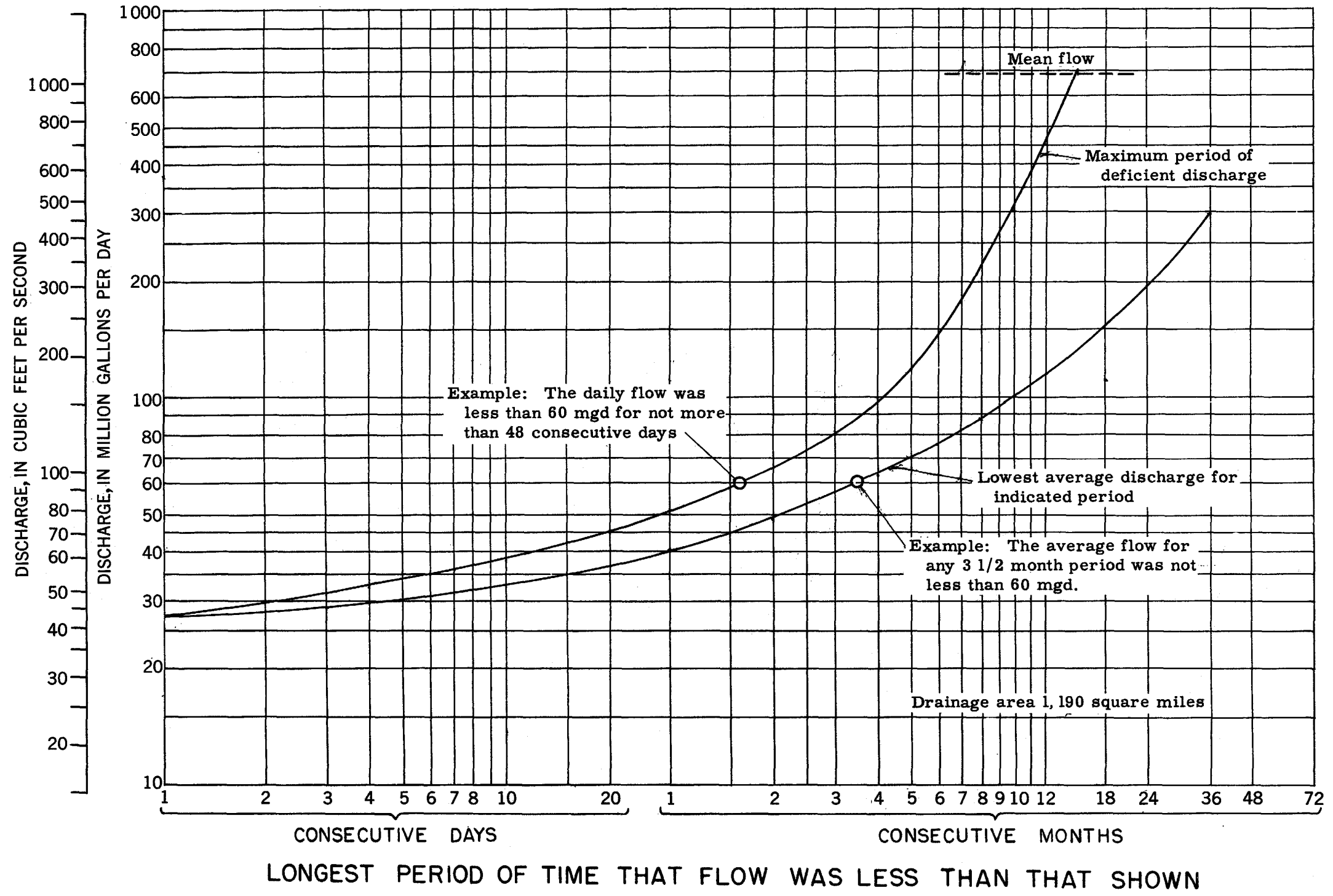

Figure 7. -Discharge available without storage, White River near Nora, 1931-51. 


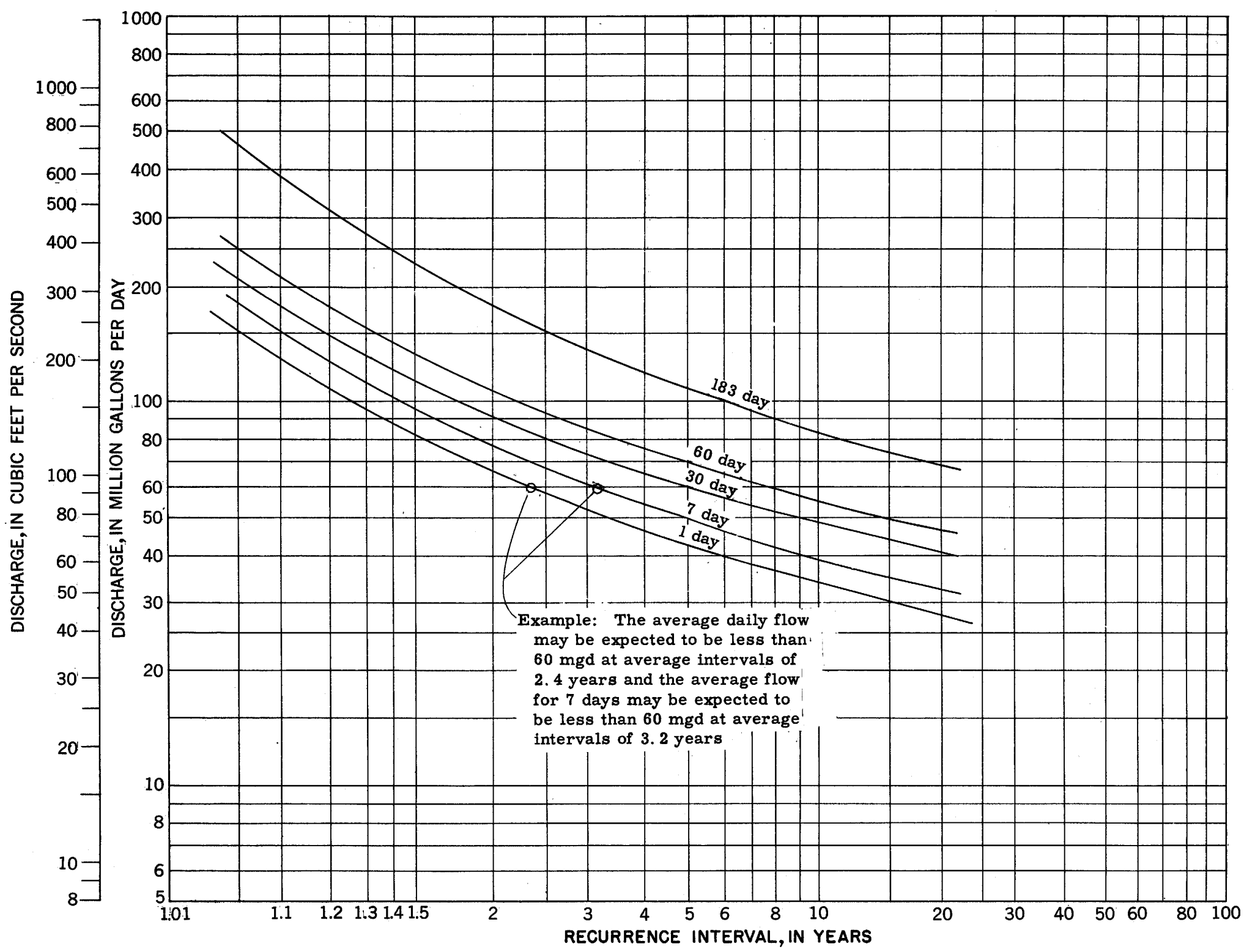

Figure 8. - Low-flow frequency curves, White River near Nora, 1931-51. 


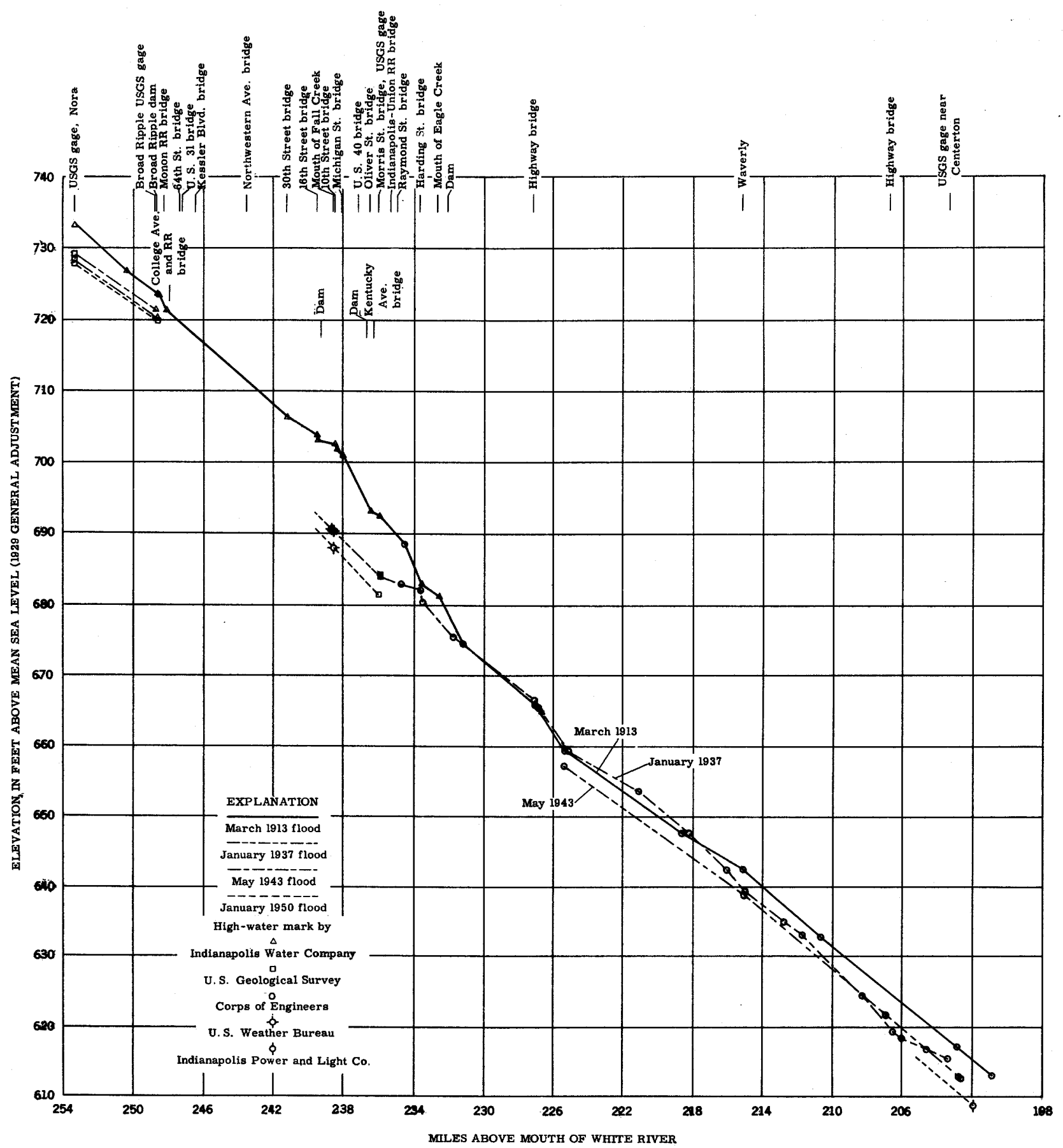

Figure 9. - Water-surface profile of selected floods on the White River from Nora to Centerton.

is returned 3 miles below the gaging station at the sewage-treatment plant.

The flow characteristics of the streams are shown by two flow-duration curves (fig. 11). Both curves are based on the discharge for the period October 1 , 1930 to September 30, 1951. The upper curve for the station at Indianapolis shows the discharge that would have occurred at Indianapolis during this period provided Geist Reservoir had been constructed earlier and had been operated the entire period in the same manner as during the period 1942-51 and provided there had been no diversion for Indianapolis water supply. The shaded area between the two curves is the approximate 1951 diversions for the Indianapolis water supply. The lower curve is the approximate quantity of water available from the White River between Washington Street bridge and the sewage-treatment plant. A smaller quantity of water is available between the Indianapolis water supply diversion and Washington 


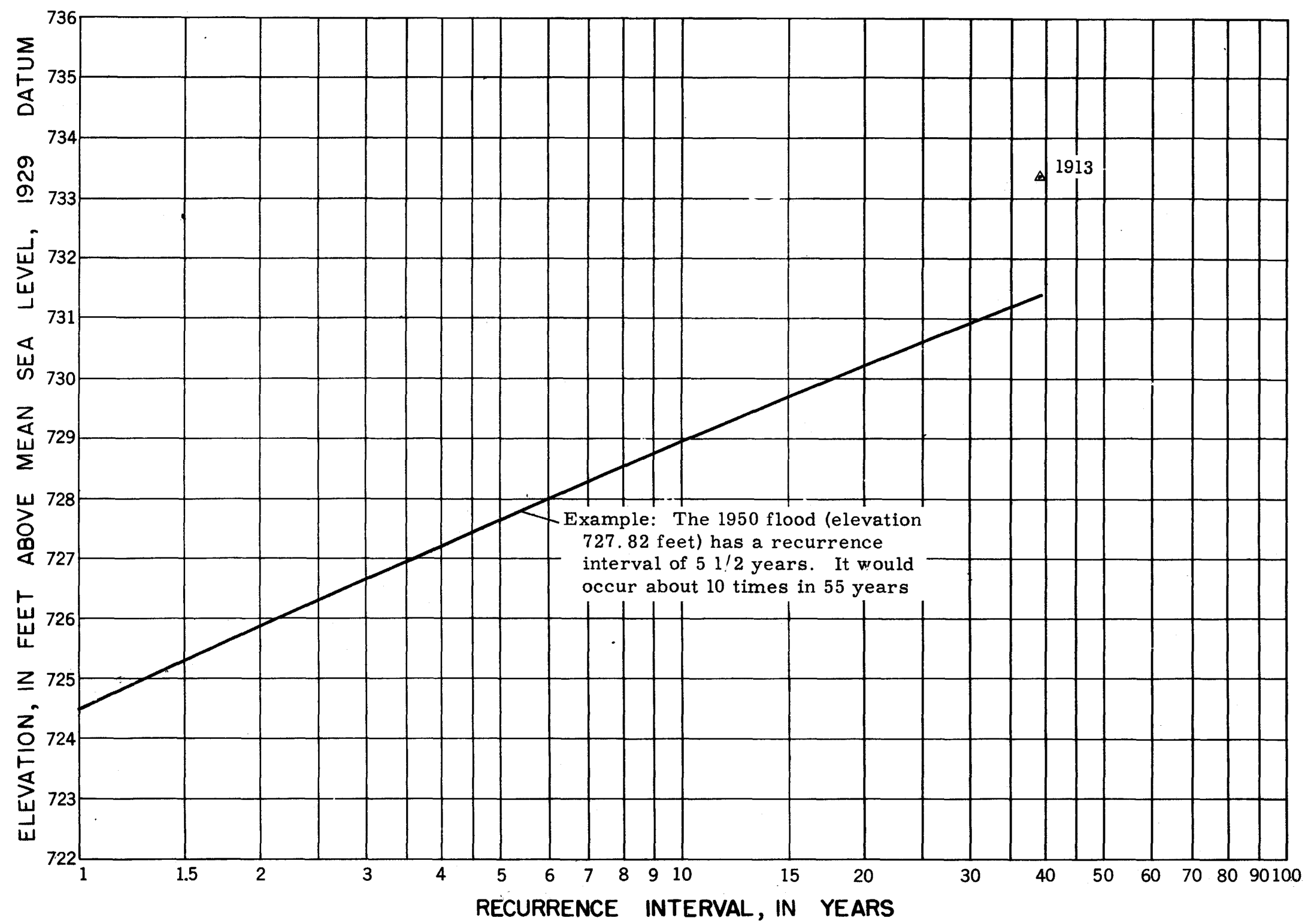




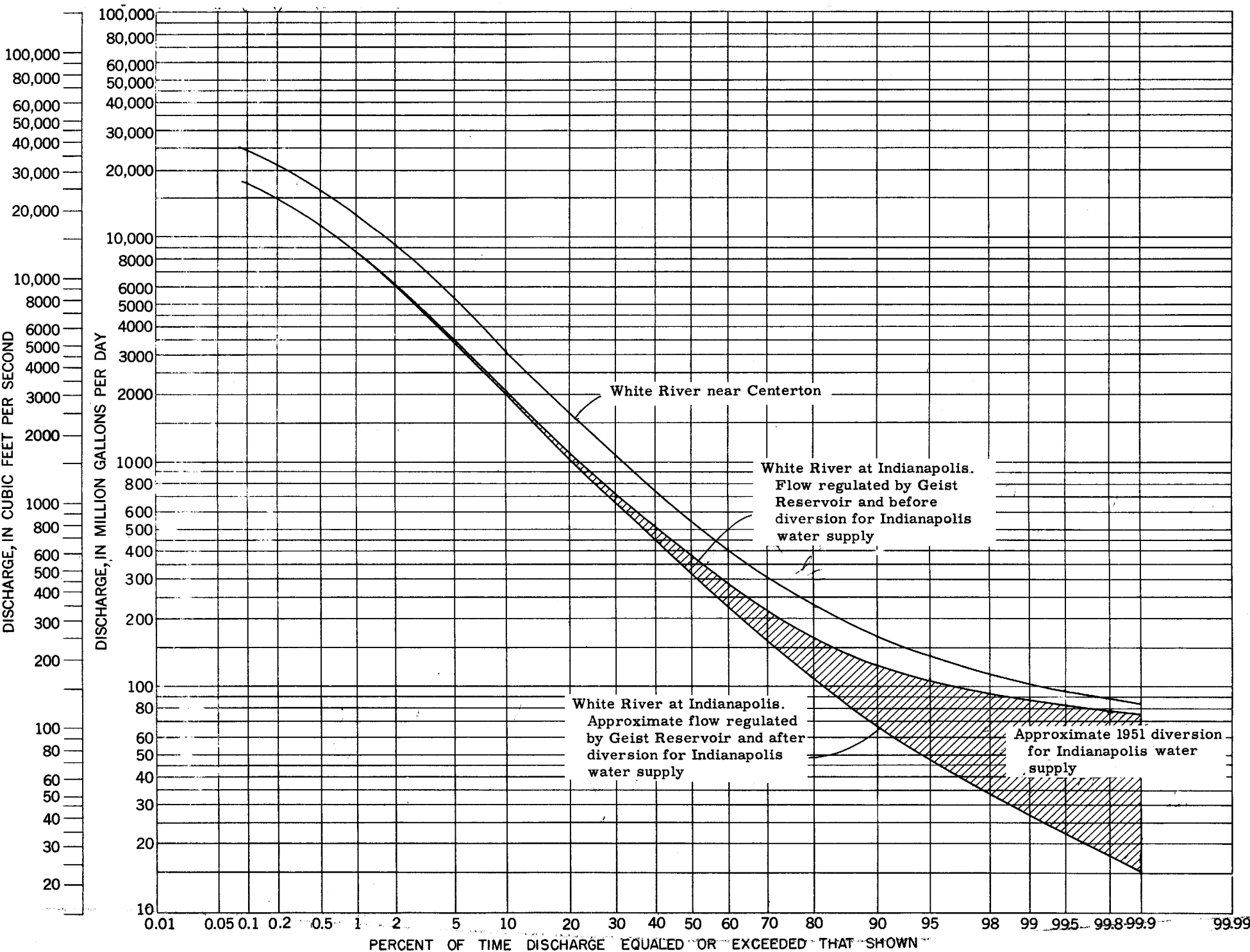

Figure 11. - Duration curve of daily flow, White River at Indianapolis and White River near Centerton, 1931-51. 
Table 1.-Selected major floods on the White River, Fall Creek, and Eagle Creek

[Elevation in feet above mean sea level]

\begin{tabular}{|c|c|c|c|c|c|c|c|c|}
\hline \multirow{2}{*}{ Stream and station } & \multicolumn{2}{|c|}{ March 1913} & \multicolumn{2}{|c|}{ January 1937} & \multicolumn{2}{|c|}{ May 1943} & \multicolumn{2}{|c|}{ January 1950} \\
\hline & Elevation 1 & $\begin{array}{c}\text { Discharge } \\
\text { (cfs) }\end{array}$ & Elevation & $\begin{array}{c}\text { Discharge } \\
\text { (cfs) }\end{array}$ & Elevation & $\begin{array}{c}\text { Discharge } \\
\text { (cfs) }\end{array}$ & Elevation & $\begin{array}{c}\text { Discharge } \\
\text { (cfs) }\end{array}$ \\
\hline Cicero Creek near Cicero.. & 788.5 & & .............. & .............. & $\ldots \ldots \ldots \ldots$ & .. & 784.80 & 5,560 \\
\hline White River near Nora..... & 733.3 & & 728.17 & 26,900 & 729.13 & 32,400 & 727.82 & 22,500 \\
\hline Fall Creek at Millersville.. & 738.5 & 1 & 733.49 & 10,300 & 733.50 & 11,100 & 733.01 & 7,400 \\
\hline Eagle Creek at Indianapolis. & 722.2 & .. & ........ & (........ & 718.38 & 9,660 & 719.24 & 8,670 \\
\hline
\end{tabular}

${ }^{1}$ From information by local residents.

Street bridge because part of the diversion in the Indianapolis Water Co. canal is returned to the river at Washington Street. The lower curve should be used for computing the quantity of water available for further development. However, if the quantity of water diverted for Indianapolis public supply is changed the curve should be changed a corresponding amount.

Floods on the White River are more likely to occur during the winter or spring than during the summer or fall. The highest stage during the year is most likely to occur in April (fig. 12). The flood of March 1913 reached an elevation of 692.3 feet above mean sea level at Morris Street according to floodmarks surveyed by the Indianapolis Water Co. Flood waters in this reach of the White River are now confined to the channel by high banks and paved levees. The dis-

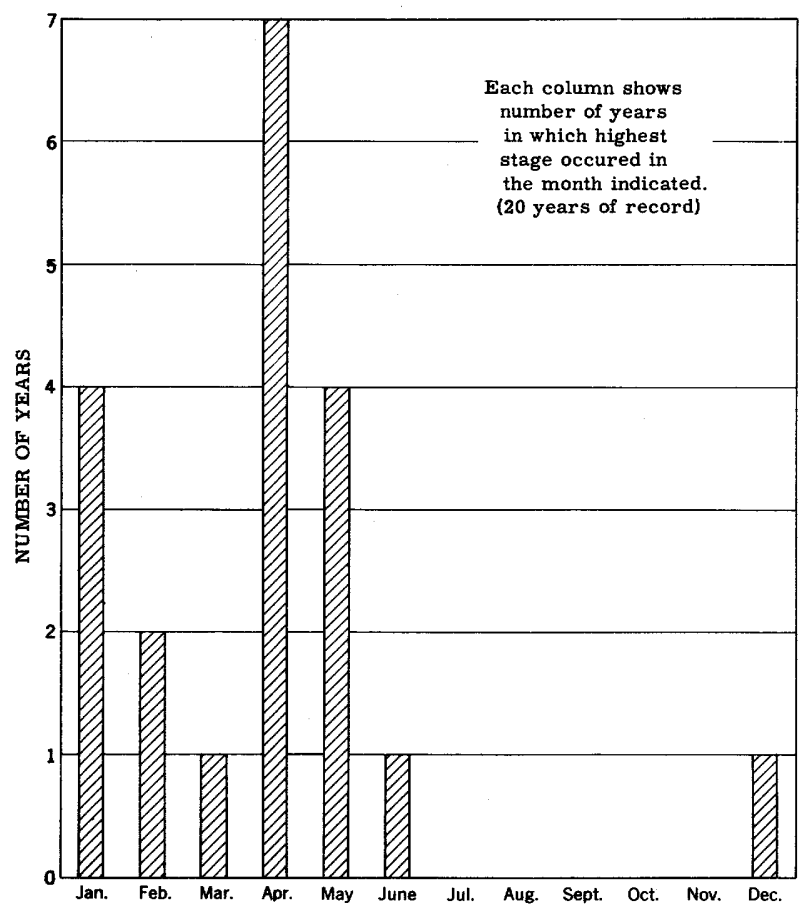

Figure 12. - Month of occurrence of highest annual stage, White River at Indianapolis. charge and stage for recent major floods are given in table 1 . The recurrence intervals of the flood elevations under present day channel and levee conditions are shown in figure 13.

\section{White River near Centerton}

At the gaging station near Centerton, about 30 miles southwest of Indianapolis the White River drains an area of 2, 340 square miles. The average discharge for water years $1947-51$, is $1,959 \mathrm{mgd}(3,031 \mathrm{cfs})$. The minimum discharge during the period 1947-53, 97 mgd (150 cfs), occurred on September 20, 1948.

The flow-duration curve in figure 11 shows the percentage of time during which a given discharge was equaled or exceeded. Because the period of record is of short duration and for a relatively wet period, the curve was computed from the flow-duration curve for White River at Indianapolis and is based on the period $1930-51$. It is more representative of the flow characteristics of the White River at Centerton than a curve computed for the period of record 1947-51.

\section{Quality}

The White River provides a calcium bicarbonate water of moderate mineral content (table 2). Samples collected in September 1952, showed a decrease in dissolved solids in the river from a point near Noblesville $(387 \mathrm{ppm})$ to the Morris Street bridge in Indianapolis (306 ppm). The dissolved solids contained about the same proportions of each substance at each of the sampling points in this section of the stream (table 3 ). Near Centerton, south of Indianapolis, the concentration of dissolved solids, $338 \mathrm{ppm}$, was greater than at Indianapolis. Increased content of sodium and chloride accounted for this increase in dissolved solids (figure 14). The percentages of both sodium and chloride in the dissolved solids were about twice as great near Centerton as they were in Indianapolis. Two samples taken in December 1952 just south of Indianapolis and farther downstream near Centerton also showed high percentages of sodium and chloride.

The alkalinity (expressed as $\mathrm{CaCO}_{3}$ ) of water from the White River varies widely (fig. 15). During the 


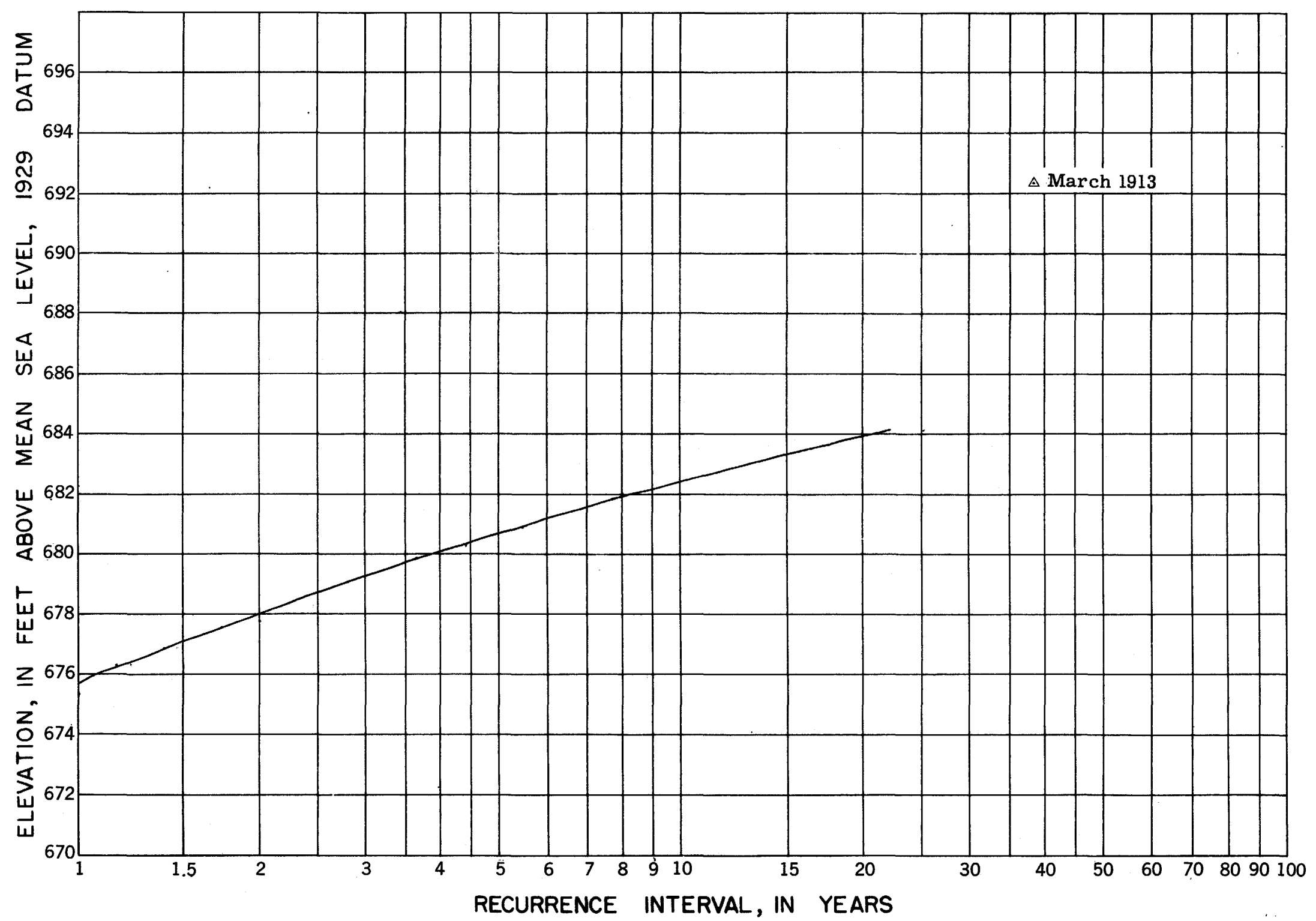

Figure 13. - Flood-stage frequencies, White River at Indianapolis, 1931-51. 
Table 2. - Chemical analyses, in parts per million, of water from selected streams in the Indianapolis area

\begin{tabular}{|c|c|c|c|c|c|c|c|c|c|c|c|c|c|c|c|c|c|c|c|c|}
\hline \multirow{2}{*}{ Source } & \multirow{2}{*}{$\begin{array}{c}\text { Date } \\
\text { of } \\
\text { collection } \\
(1952)\end{array}$} & \multirow{2}{*}{$\begin{array}{c}\text { Instan- } \\
\text { taneous } \\
\text { discharge } \\
\text { (cfs) }\end{array}$} & \multirow{2}{*}{$\begin{array}{l}\text { Water } \\
\text { temper- } \\
\text { ature } \\
\left({ }^{\circ} \mathrm{F}\right)\end{array}$} & \multirow{2}{*}{$\begin{array}{l}\text { Silica } \\
\left(\mathrm{SiO}_{2}\right)\end{array}$} & \multirow{2}{*}{$\begin{array}{l}\text { Iron } \\
(\mathrm{Fe})\end{array}$} & \multirow{2}{*}{$\begin{array}{l}\text { Cal- } \\
\text { cium } \\
\text { (Ca) }\end{array}$} & \multirow{2}{*}{$\begin{array}{c}\text { Mag- } \\
\text { nessium } \\
\text { (Mg) }\end{array}$} & \multirow{2}{*}{$\begin{array}{l}\text { So- } \\
\text { dium } \\
\text { (Na) }\end{array}$} & \multirow{2}{*}{$\begin{array}{l}\text { Po- } \\
\text { tas- } \\
\text { sium } \\
(\mathrm{K})\end{array}$} & \multirow{2}{*}{$\begin{array}{l}\text { Bicar- } \\
\text { bonate } \\
\left(\mathrm{HCO}_{3}\right)\end{array}$} & \multirow{2}{*}{$\begin{array}{l}\text { Sul- } \\
\text { fate } \\
\left(\mathrm{SO}_{4}\right)\end{array}$} & \multirow{2}{*}{$\begin{array}{l}\text { Chlo- } \\
\text { ride } \\
\text { (Cl) }\end{array}$} & \multirow{2}{*}{$\begin{array}{l}\text { Fluo- } \\
\text { ride } \\
\text { (F) }\end{array}$} & \multirow{2}{*}{$\begin{array}{c}\mathrm{Ni}- \\
\text { trate } \\
\left.\text { ( } \mathrm{NO}_{\mathrm{g}}\right)\end{array}$} & \multirow{2}{*}{$\begin{array}{c}\text { Dissolved } \\
\text { solids } \\
\text { (residue } \\
\text { on evap- } \\
\text { oration } \\
\text { at } 180^{\circ} \mathrm{C} \text { ) }\end{array}$} & \multicolumn{2}{|c|}{$\begin{array}{l}\text { Hardness } \\
\text { as } \mathrm{CaCO}_{3} \text {. }\end{array}$} & \multirow{2}{*}{$\begin{array}{l}\text { Specific } \\
\text { conduct- } \\
\text { ance at } \\
25^{\circ} \mathrm{C} \\
\text { (micromhos) }\end{array}$} & \multirow{2}{*}{$\mathrm{pH}$} & \multirow{2}{*}{ Color } \\
\hline & & & & & & & & & & & & & & & & $\begin{array}{c}\text { Calcium, } \\
\text { mag- } \\
\text { nesium }\end{array}$ & $\begin{array}{l}\text { Non- } \\
\text { carbon } \\
\text { ate }\end{array}$ & & & \\
\hline 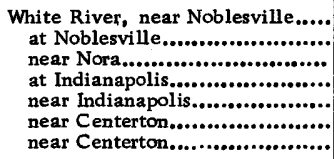 & $\begin{array}{l}\text { Sept. } 24 \\
24 \\
25 \\
25 \\
25 \\
\text { Dec. } 5 \\
\text { Sept. } 25 \\
\text { Dec. } 5\end{array}$ & $\begin{array}{r}322 \\
309 \\
470 \\
565 \\
694 \\
848 \\
1,100\end{array}$ & $\begin{array}{l}62 \\
59 \\
62 \\
68 \\
40 \\
68 \\
40\end{array}$ & $\begin{array}{l}14 \\
13 \\
12 \\
11 \\
9.6 \\
11 \\
10\end{array}$ & $\begin{array}{l}0.03 \\
.04 \\
.04 \\
.05 \\
.02 \\
.04 \\
.04\end{array}$ & $\begin{array}{l}81 \\
75 \\
75 \\
63 \\
77 \\
62 \\
85\end{array}$ & $\begin{array}{l}25 \\
26 \\
23 \\
18 \\
25 \\
18 \\
26\end{array}$ & $\begin{array}{l}12 \\
12 \\
9.5 \\
12 \\
34 \\
25 \\
35\end{array}$ & $\begin{array}{l}1.9 \\
1.9 \\
1.4 \\
1.8 \\
3.8 \\
2.9 \\
4.1\end{array}$ & $\begin{array}{l}288 \\
267 \\
265 \\
212 \\
258 \\
216 \\
284\end{array}$ & $\begin{array}{l}75 \\
75 \\
67 \\
61 \\
90 \\
57 \\
90\end{array}$ & $\begin{array}{c}13 \\
12 \\
9.0 \\
11 \\
36 \\
28 \\
41\end{array}$ & $\begin{array}{r}0.2 \\
.3 \\
.2 \\
.3 \\
.3 \\
.4 \\
.3\end{array}$ & $\begin{array}{c}7.0 \\
9.6 \\
8.6 \\
7.2 \\
13 \\
5.8 \\
17\end{array}$ & $\begin{array}{l}\mathbf{3 8 7} \\
373 \\
\mathbf{3 4 8} \\
\mathbf{3 0 6} \\
\mathbf{4 1 6} \\
\mathbf{3 3 8} \\
\mathbf{4 4 7}\end{array}$ & $\begin{array}{l}304 \\
294 \\
284 \\
233 \\
294 \\
231 \\
320\end{array}$ & $\begin{array}{l}69 \\
75 \\
65 \\
58 \\
84 \\
52 \\
86\end{array}$ & $\begin{array}{l}615 \\
607 \\
591 \\
507 \\
689 \\
572 \\
746\end{array}$ & $\begin{array}{l}7.2 \\
7.3 \\
7.1 \\
7.1 \\
6.8 \\
7.0 \\
7.0\end{array}$ & $\begin{array}{r}18 \\
9 \\
20 \\
22 \\
10 \\
15 \\
10\end{array}$ \\
\hline 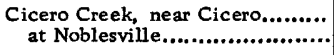 & $\begin{array}{l}\text { Sept. } 24 \\
24\end{array}$ & $\begin{array}{l}53 \\
60\end{array}$ & $\begin{array}{l}56 \\
60\end{array}$ & $\begin{array}{l}11 \\
12\end{array}$ & $\begin{array}{l}.03 \\
.05\end{array}$ & $\begin{array}{l}64 \\
64\end{array}$ & $\begin{array}{l}19 \\
19\end{array}$ & $\begin{array}{l}7.0 \\
4.9\end{array}$ & $\begin{array}{l}1.4 \\
1.4\end{array}$ & $\begin{array}{l}238 \\
240\end{array}$ & $\begin{array}{l}45 \\
39\end{array}$ & $\begin{array}{l}8.0 \\
5.0\end{array}$ & .2 & $\begin{array}{l}5.5 \\
3.6\end{array}$ & $\begin{array}{l}285 \\
282\end{array}$ & $\begin{array}{l}240 \\
238\end{array}$ & $\begin{array}{l}43 \\
41\end{array}$ & $\begin{array}{l}489 \\
470\end{array}$ & $\begin{array}{l}7.6 \\
7.4\end{array}$ & $\begin{array}{l}8 \\
8\end{array}$ \\
\hline 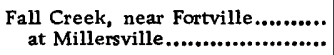 & $\begin{array}{l}24 \\
25\end{array}$ & $\begin{array}{l}48 \\
67\end{array}$ & $\begin{array}{l}57 \\
59\end{array}$ & $\begin{array}{c}11 \\
5.2\end{array}$ & $\begin{array}{l}.06 \\
.03\end{array}$ & $\begin{array}{l}94 \\
51\end{array}$ & $\begin{array}{l}27 \\
24\end{array}$ & $\begin{array}{l}4.5 \\
3.7\end{array}$ & $\begin{array}{r}1.2 \\
.8\end{array}$ & $\begin{array}{l}332 \\
228\end{array}$ & $\begin{array}{l}75 \\
43\end{array}$ & $\begin{array}{l}5.5 \\
7.0\end{array}$ & $\begin{array}{l}.2 \\
.2\end{array}$ & $\begin{array}{l}7.0 \\
1.1\end{array}$ & $\begin{array}{l}402 \\
257\end{array}$ & $\begin{array}{l}346 \\
227\end{array}$ & $\begin{array}{l}74 \\
39\end{array}$ & $\begin{array}{l}653 \\
449\end{array}$ & $\begin{array}{l}7.7 \\
7.4\end{array}$ & $\begin{array}{l}5 \\
5\end{array}$ \\
\hline Eagle Creek at Indianapolis.......... & 25 & 46 & 62 & 11 & .04 & 66 & 19 & 4.2 & 1.3 & 250 & 37 & 6.0 & .1 & 3.2 & 283 & 244 & 38 & 474 & 7.7 & 10 \\
\hline 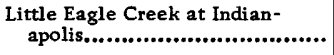 & 24 & 2.55 & 62 & 9.9 & .08 & 75 & 26 & 66 & 1.6 & 304 & 91 & 70 & .1 & 3.0 & 503 & 294 & 45 & 843 & 7.6 & 12 \\
\hline $\begin{array}{l}\text { Lawrence Creek at Fort Benjamin } \\
\text { Harrisonn }\end{array}$ & 24 & 1.4 & 60 & 13 & .07 & 109 & 38 & 19 & 1.8 & 303 & 195 & 15 & .2 & 11 & 574 & 430 & 180 & 885 & 7.6 & 6 \\
\hline Lick Creek at Indianapolis.......... & 24 & 4.22 & 59 & 13 & .05 & 82 & 27 & 27 & 2.2 & 314 & 79 & 20 & .4 & 9.2 & 427 & 316 & 58 & 705 & 7.5 & 8 \\
\hline Pleasant Run at Indianapolis....... & 24 & 1.77 & 57 & 9.4 & .04 & 90 & 30 & 28 & 1.8 & 282 & 137 & 30 & .4 & 5.6 & 488 & 350 & 117 & 798 & 7.4 & 5 \\
\hline
\end{tabular}


Table 3.-Composition of dissolved solids in water from selected streams

[Percent of dissolved solids]

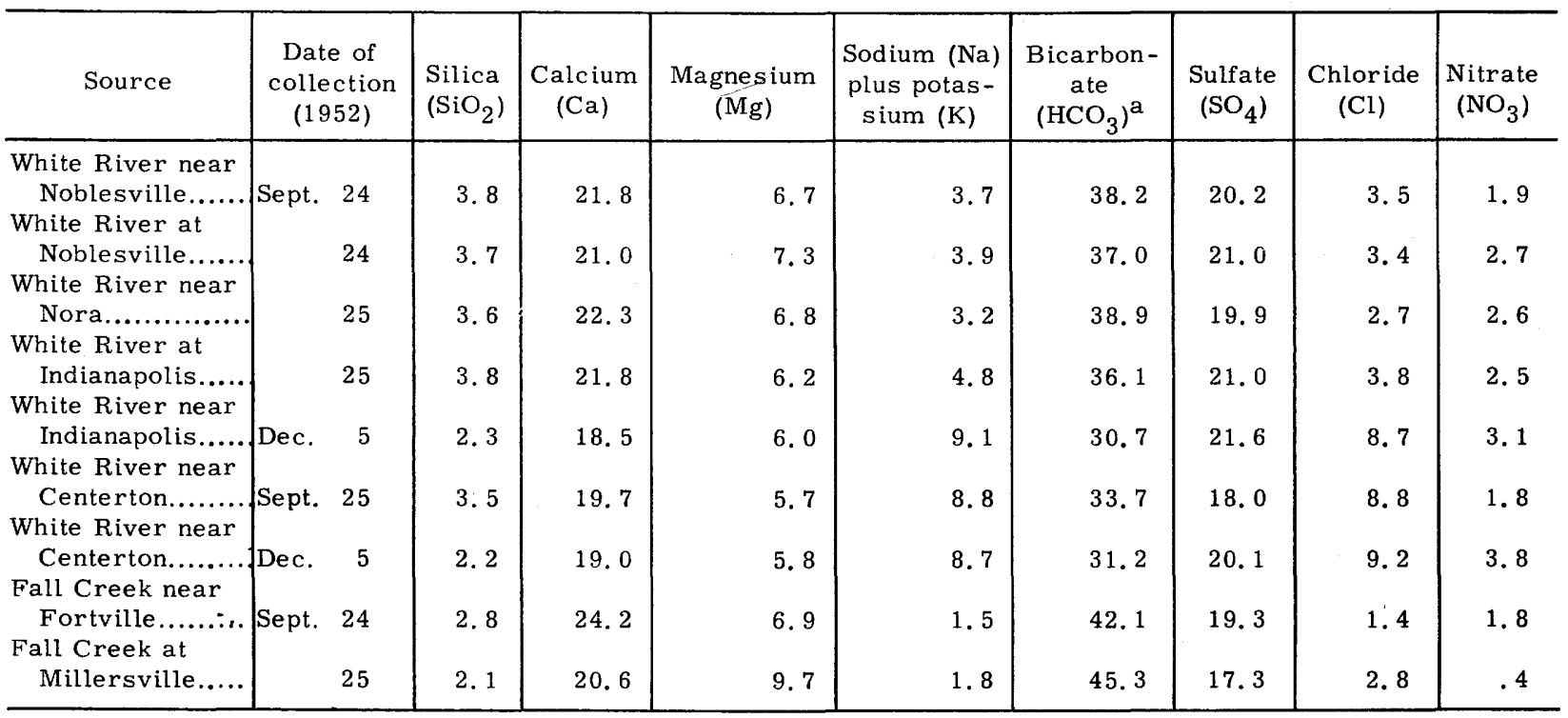

${ }^{a}$ Calculated as carbonate equivalent.

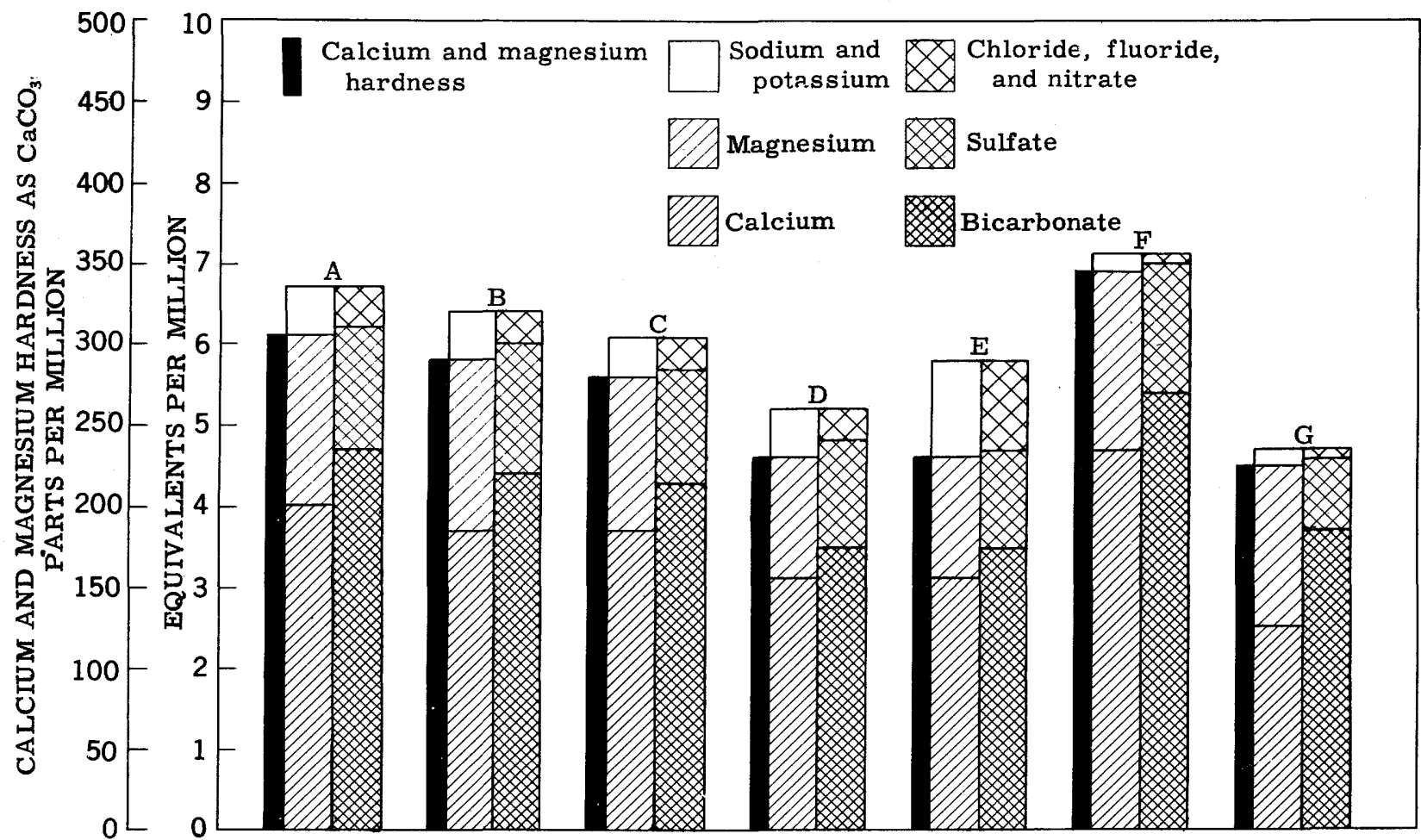
A. White River near Noblesville
B. White River at Noblesville
C. White River near Nora
D. White River at Indianapolis

E. White River near Centerton

F. Fall Creek near Fortville

G. Fall Creek at Millersville 

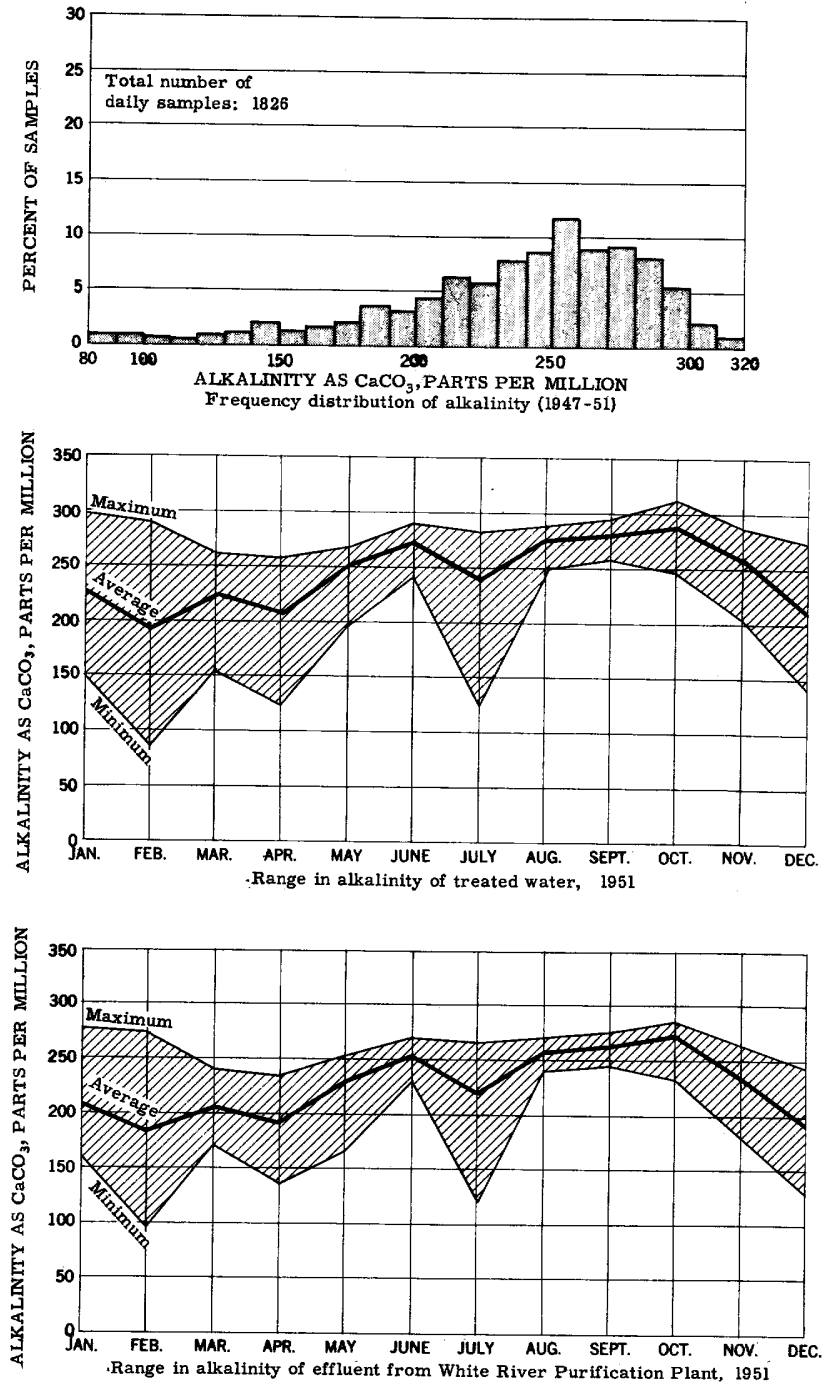

Figure 15. - Alkalinity of water from the White River at Indianapolis. (Data from Annual Laboratory Reports, Indianapolis Water Co.)

5 year period from 1947 to 1951 , the alkalinity ranged from 70 to $327 \mathrm{ppm}$, and during 1951 ranged from 86 to $296 \mathrm{ppm}$. During $1947-51$, the alkalinity of $54 \mathrm{per}-$ cent of the samples was in the range from 231 to 290 ppm (fig. 15). In the years from 1947 to 1951 the alkalinity of $50,56,56,46$, and 65 percent of the samples respectively fell within this range.

The water of the White River is hard and the hardness varies much as the alkalinity does. The hardness (as $\mathrm{CaCO}_{3}$ ) of samples collected at five places in the area during September 1952, ranged from 231 to 304 ppm. About one-fourth of the hardness in each sample was noncarbonate.

During the 5-year period from. 1947 to 1951 the temperature of water in the Indianapolis Water Co. canal ranged from about $32^{\circ} \mathrm{F}$ to about $83^{\circ} \mathrm{F}$ (fig. 16). An investigation showed that the temperature of the canal water is indicative of the temperature of water in the White River. The cumulative frequency curve of temperature shows the percent of the time that the water temperature was equal to or greater than a selected value. For example, it may be anticipated that White River water will have a temperature of $65^{\circ} \mathrm{F}$ or greater for about 36 percent of the time, and that the temperature will be between $40^{\circ} \mathrm{F}$ and $70^{\circ} \mathrm{F}$ for about 52 percent of the time. The temperature of water from the White River is increased by the powerplant at Clare, however, most of the heat imparted to the water by the powerplant is dissipated by the time the water reaches the gage at Noblesville.

\section{Flood Control}

Indianapolis suffered heavy damage in the 1913 flood. A comprehensive flood protection plan was developed shortly thereafter. The plan provided for improvement of the channel of the White River from Broad Ripple Dam, near the upstream limits of the city, downstream to a point below the mouth of Eagle Creek. It also provided for improvement of the channel of Eagle Creek and Fall Creek within the city. Flood walls and levees were to be constructed where necessary.

Construction was started in 1915. One channel change has been made and a large part of the channel enlargement has been completed. A considerable quantity of material was removed from the channel, although it was insufficient to make the channel conform with the original plan. The levee and wall along the right bank of the White River has been completed and the channel bank paved where necessary. On the left bank a levee was built from the Indianapolis Union Railway downstream to the mouth of Fall Creek and up Fall Creek to Indiana Avenue. On the left bank below Fall Creek a levee conforming to the adopted plan has been built as far as Michigan Street. Between Michigan and Washington Streets the city has built another levee of which only 350 feet of concrete wall near Washington Street conforms to the adopted plan.

The channel improvement has involved the construction and reconstruction of a large number of bridges to provide larger waterway areas.

\section{Cicero Creek}

Cicero Creek rises in the southwestern part of Tipton County, about 30 miles north of Indianapolis; it flows eastward to Tipton then southward into the White River at Noblesville. It drains a square-shaped tillplain area of more than 206 square miles. Cicero Creek is important to the future development and expansion of the Indianapolis water supply. The Indianapolis Water Co. is constructing a reservoir on Cicero Creek north of Noblesville to increase the low-water flow of the White River. The reservoir will have about the same capacity as Geist Reservoir on Fall Creek, or 6,900 million gallons. Streamflow records are collected at two gaging stations on Cicero Creek. Both records are of short duration. 


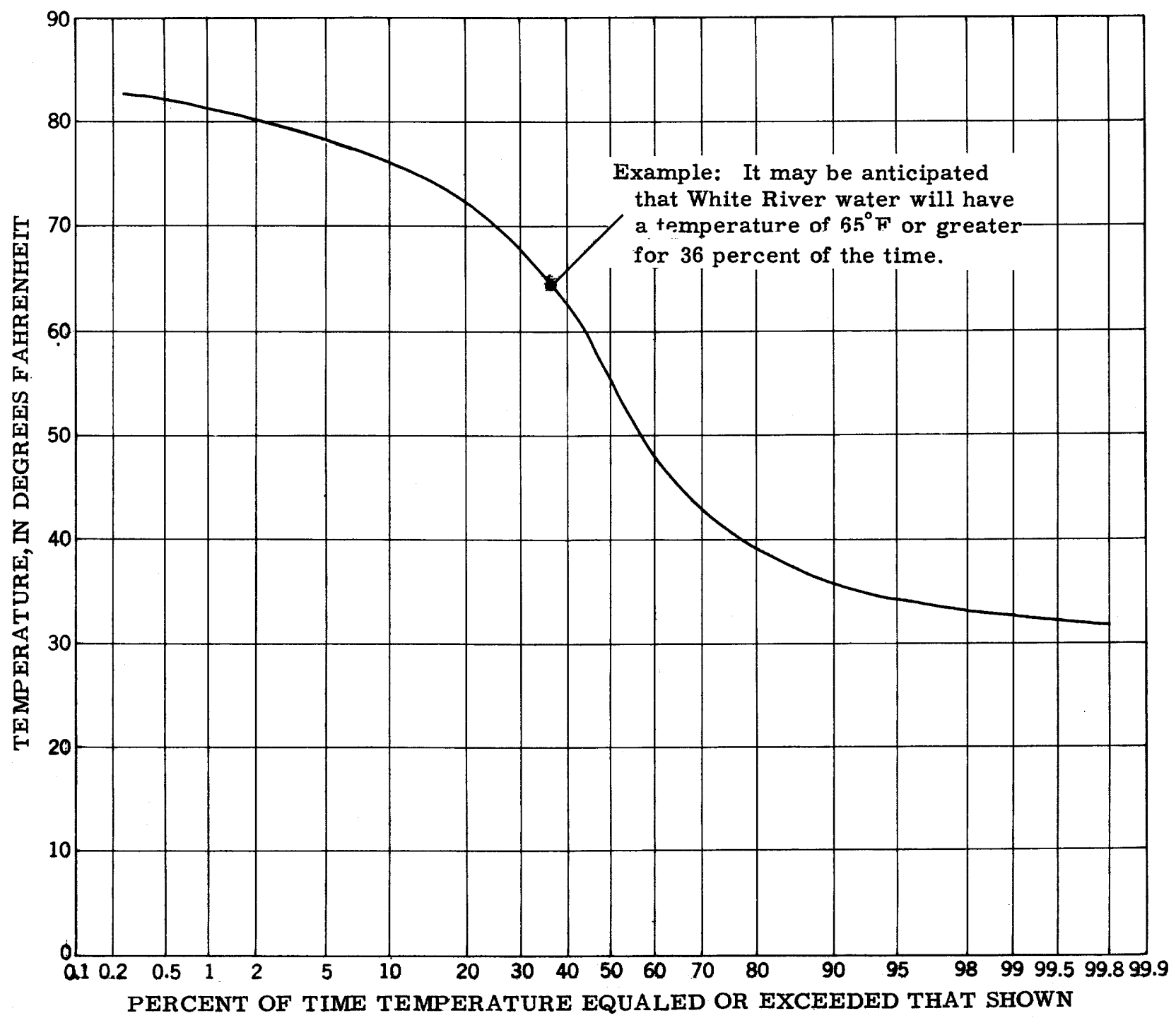

Figure 16. - Cumulative frequency curve of temperature, White River at Indianapolis, 1947-51.

Cicero Creek near Cicero

Cicero Creek drains an area of 178 square miles at the county highway bridge 3 miles south of Cicero and $2 \frac{1}{4}$ miles above Hinkle Creek. The average discharge for the water years $1947-51$ is $138 \mathrm{mgd}$ ( $214 \mathrm{cfs})$. The minimum discharge during the period April 1946 to September $1951,0.78$ mgd (1.2 cfs), occurred October 14, 1946, and September 21, 1951. A smaller flow, $0.3 \mathrm{mgd}(0.4 \mathrm{cfs})$, occurred on October 6, 1951.

The flow characteristics for Cicero Creek are shown by the duration curve of daily flow (fig. 17). The curve was computed from records of flow for the White River near Noblesville during water years 1930-51 and the records for Cicero Creek near Cicero for water years 1947-51. It is a better indication of the flow that may be expected during a long period than a curve based exclusively on data for Cicero Creek. In general, the flow-duration curve for Cicero Creek is steeper and straighter than the curves for the White River in the Indianapolis area. This indicates a greater variability of flow and a lesser sustaining flow from ground-water storage in Cicero Creek than in the main stream.

\section{Cicero Creek at Noblesville}

A gaging station was established on Cicero Creek at Noblesville in July 1950 , at State Highway 38 , and $1 \frac{1}{2}$ miles above the mouth. At the gage the creek drains an area of 206 square miles. The average discharge for the 1951 water year was $139 \mathrm{mgd}(216 \mathrm{cfs})$. The duration curve of daily flow for the station at Noblesville is a close approximation of the curve for the station near Cicero (fig. 17). 


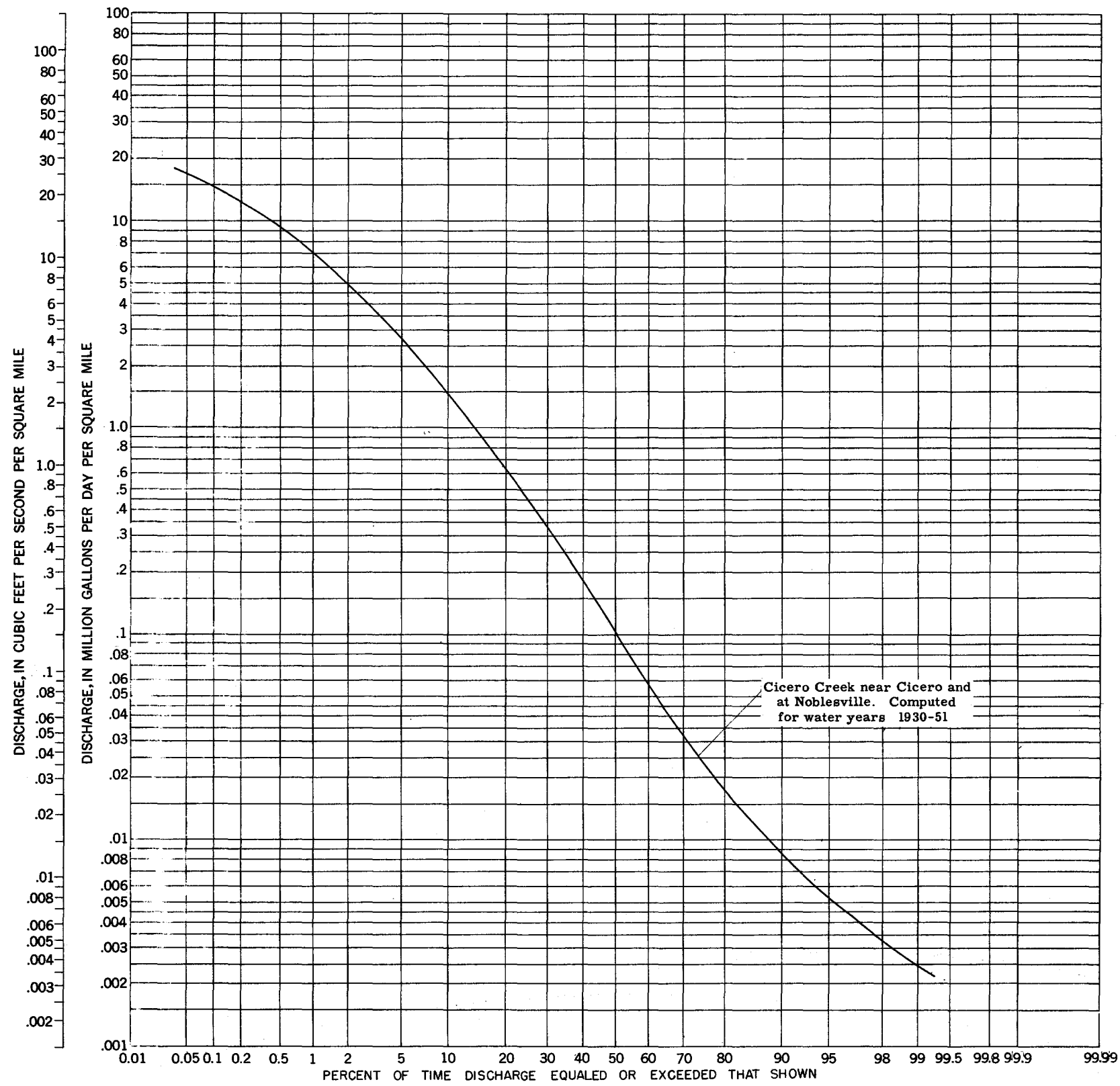

Figure 17. - Duration curve of daily flow, Cicero Creek

\section{Quality}

Analyses of samples of water collected at each of the stations on Cicero Creek indicate that the water is similar in chemical quality to water from the White River. (See table 2.)

\section{Fall Creek}

Fall Creek rises in the northwestern corner of Henry County and flows southwestward into the White River in the northern part of Indianapolis. The drainage basin is long and narrow, roughly parallel to the upper White River, and covers an area of about 320 square miles. The Indianapolis Water Co. diverts water from
Fall Creek at Keystone Avenue for the city water supply. In order to increase the availability of flow Geist Reservoir (capacity 6,900 million gallons) was constructed about 16 miles northeast of Indianapolis near Oaklandon. Storage began on December 29, 1942. Records of streamflow are collected at two gaging stations on Fall Creek, one above and one below Geist Reservoir.

\section{Fall Creek near Fortville}

Fall Creek drains an area of 175 square miles at State Highway 238, 2 miles northwest of Fortville, and several miles above Geist Reservoir. The average discharge for the 10-year period of record 1942-51 


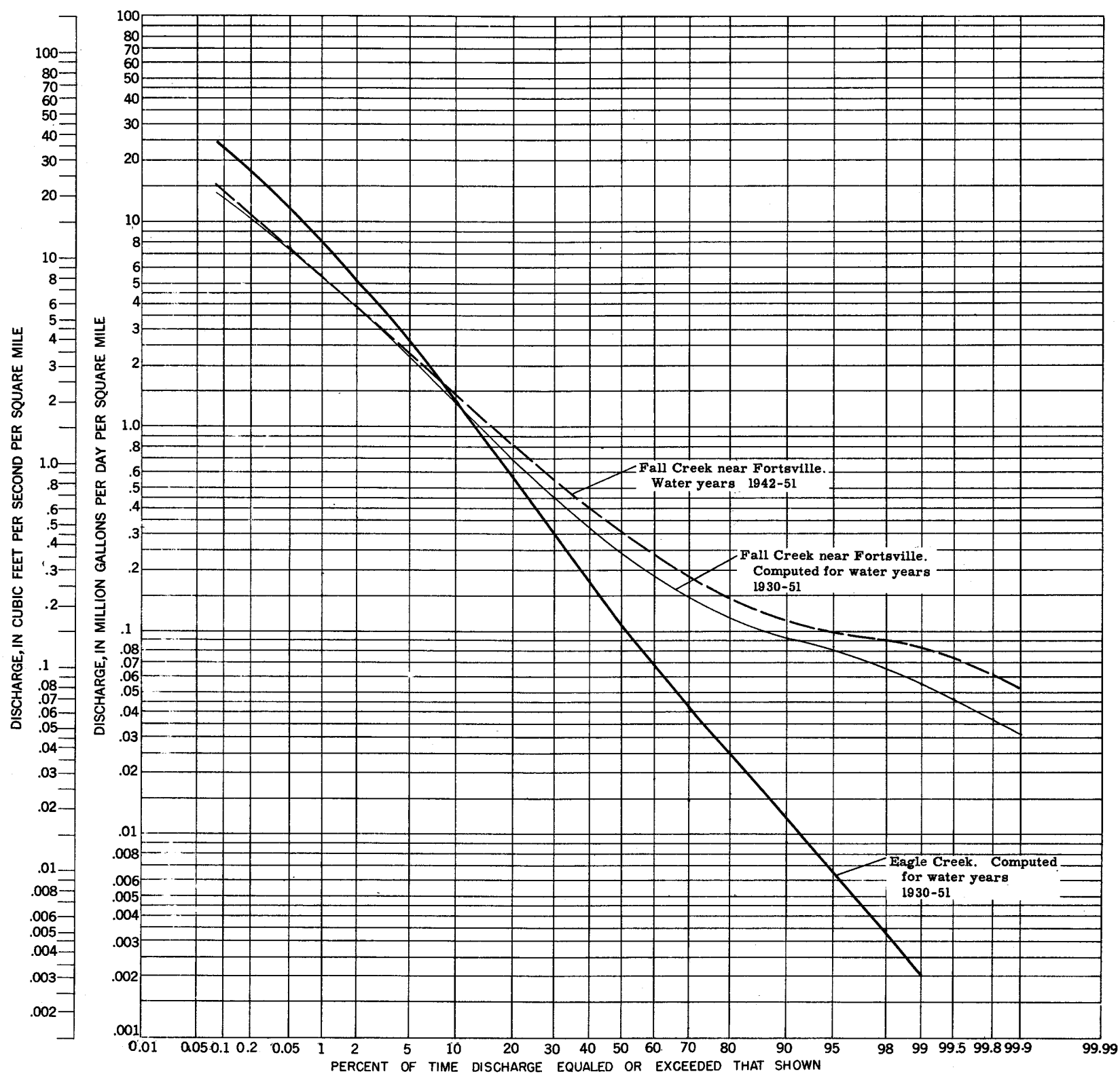

Figure 18. -Duration curve of daily flow, Fall Creek and Eagle Creek.

is $114 \mathrm{mgd}$ (177 cfs). The minimum discharge during the period July 1941 to September $1953,3.2 \mathrm{mgd}(5.0$ cfs), occurred September 23, 24, 1941.

The flow characteristics are shown by the duration curve of daily flow (fig. 18). The slope of the curve is relatively flat, which indicates a moderate range in flow or a relatively steady flow. Streams having a steady flow are most suitable as sources of water supply. During periods of low flow, storage may be required in order to maintain specific flows. Figure 19 shows a graph of net storage, exclusive of evaporation and dead storage, necessary to maintain designated outflow rates per square mile of drainage area. For example, net storage of 254 million gallons per square mile would be required to maintain an outflow of 0.45 mgd ( $0.7 \mathrm{cfs})$ per square mile. The diagram is based on the record of flow for water years $1942-51$ and an estimated record for the drought period of 1939-41, which was based on the record at Millersville.

\section{Fall Creek at Millersville}

At Millersville, $8 \frac{1}{2}$ miles upstream from the mouth, Fall Creek drains an area of 306 square miles. The average discharge for 22 years (water years 1926 , $1931-51)$ is $175 \mathrm{mgd}(270 \mathrm{cfs})$, and the minimum discharge during water years $1926,1931-53,4.5 \mathrm{mgd}$ (7.0 cfs), occurred September 28, 1941. Since December 1942, the low flows have been maintained by the Indianapolis Water Co.'s Geist Reservoir about 8 miles upstream. 

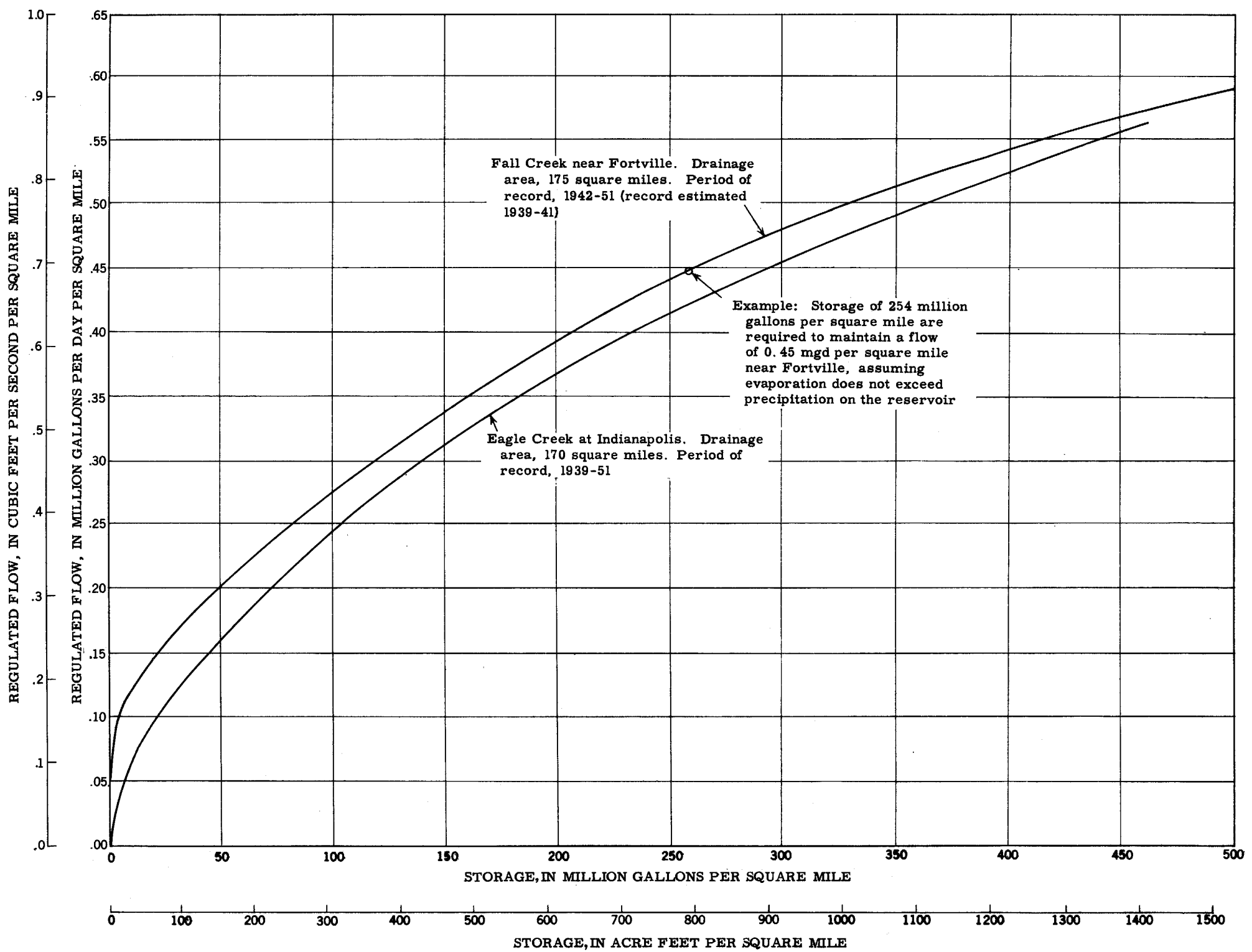

Figure 19. - Storage requirements, Fall Creek near Fortville and Eagle Creek at Indianapolis. 


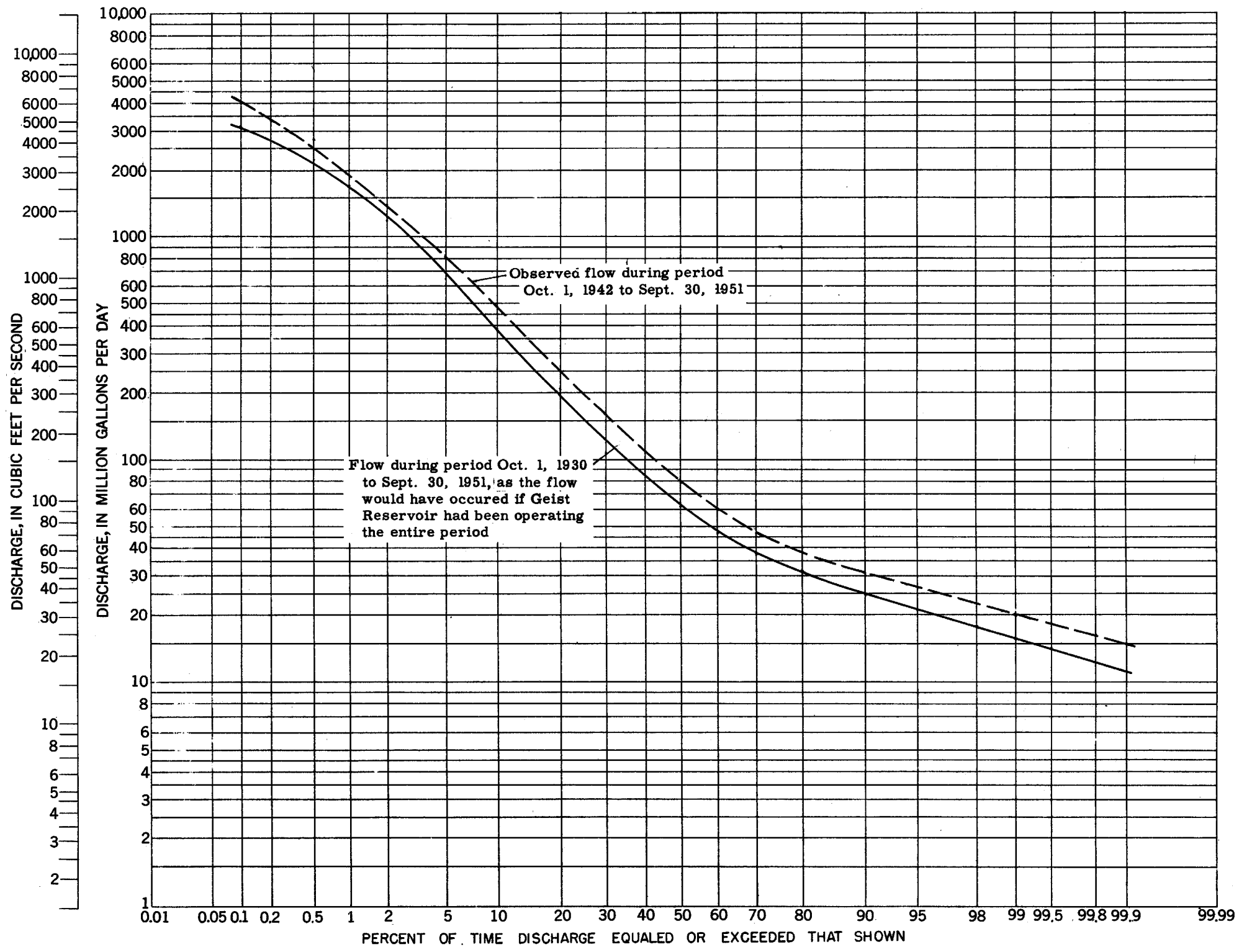

Figure 20. - Duration curve of daily flow, Fall Creek at Millersville. 


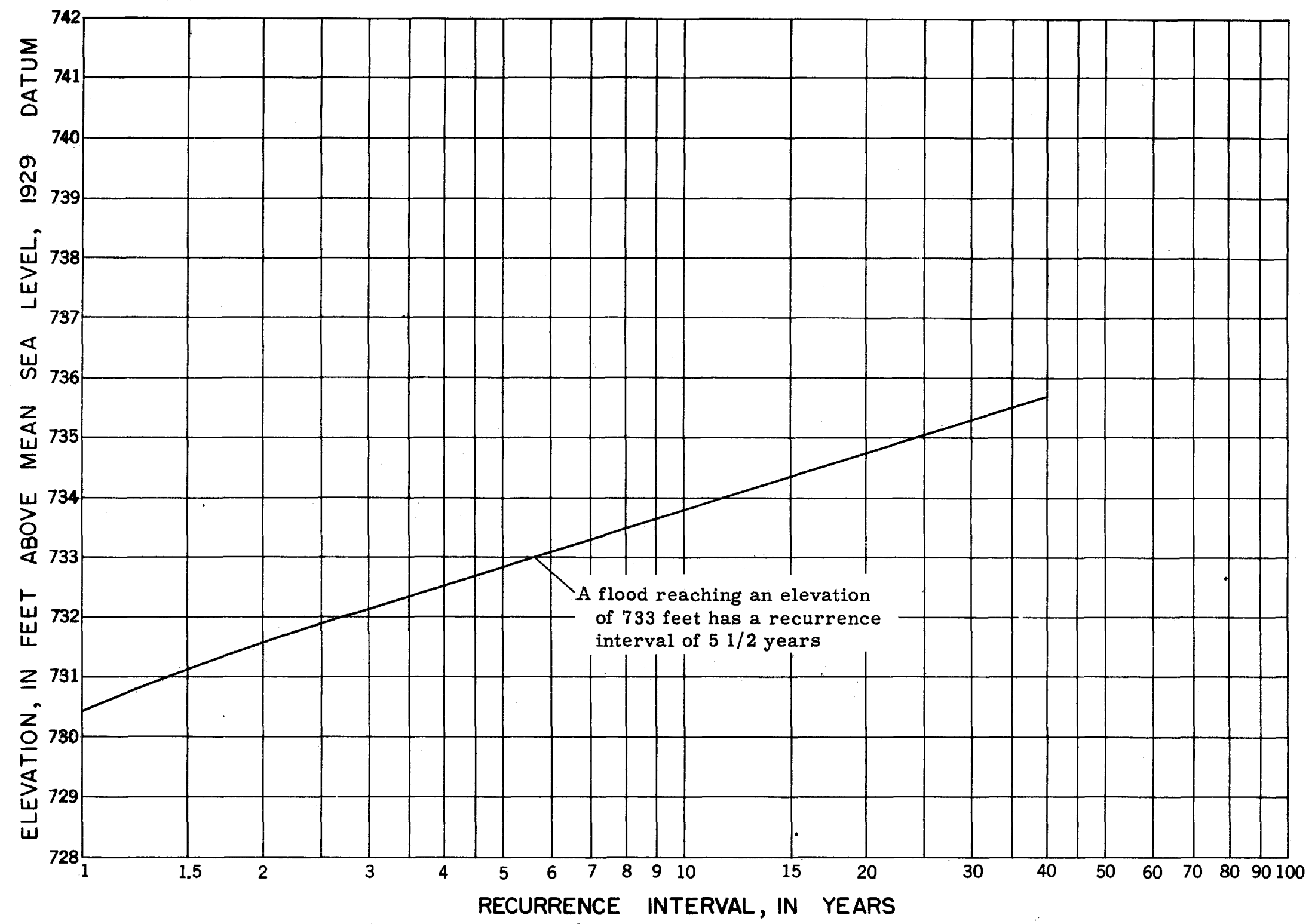

Figure 21. - Flood-stage frequencies, Fall Creek at Millersville, 1931-51. 


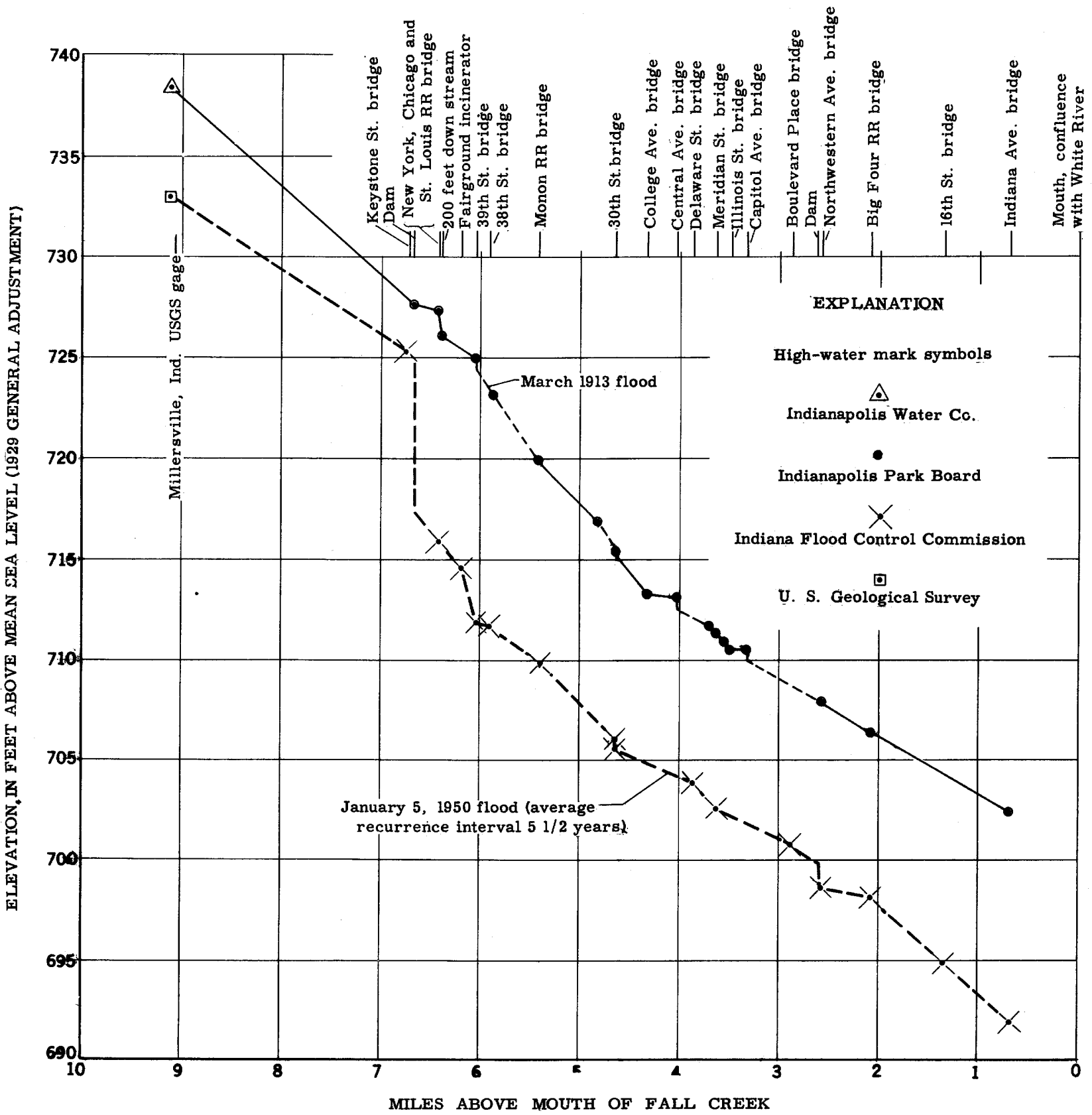

Figure 22. - Water-surface profile of Fall Creek for the 1913 and 1950 floods.

The flow characteristics are shown by the duration curve of daily flow (fig. 20). Data for the period from October 1, 1930, to September 30, 1942 have been adjusted so that the curve represents present conditions provided that Geist Reservoir is operated in the same manner as during the period 1943-51.

During the highest flood in recent time, March 1913, Fall Creek reached a stage of 738.5 feet above mean sea level at the gaging station at Millersville. Discharge and stage for other recent floods are shown in table 1. The recurrence interval of floods on Fall Creek at Millersville under present day channel and levee conditions are shown in figure 21 . The water- surface profile of Fall Creek from Nora gage to the mouth for the 1913 and 1950 floods is shown in figure 22.

The flood of 1950 (elevation 733 feet) has a recurrence interval of $5 \frac{1}{2}$ years (fig. 21). Other points on the 1950 flood profile (fig. 22) may also be flooded at about $5 \frac{1}{2}$-year intervals. For example, at the Monon Railroad bridge an elevation of 710 feet (elevation reached by the 1950 flood) may be expected to be reached by floods at average intervals of $5 \frac{1}{2}$ years. This does not mean that it will be flooded at uniform $5 \frac{1}{2}$-year intervals, but that it will be flooded about 10 times in 55 years or 20 times in 110 years. 
Quality

The chemical character of water from Fall Creek in the vicinity of Fortville resembles that of water from the White River near Noblesville. (See table 2.) There was, however, a notable difference in the concentrations of sodium and chloride in the two streams. Fall Creek contained less sodium and chloride and more calcium and bicarbonate than the White River. At Millersville the dissolved--solids content was about one-third less than it was near Fortville. The percentage composition of the dissolved solids was about the same at the two points. (See table 3.) Water from Fall Creek, like that of the White River, is of the calcium bicarbonate type and of moderate mineral content.
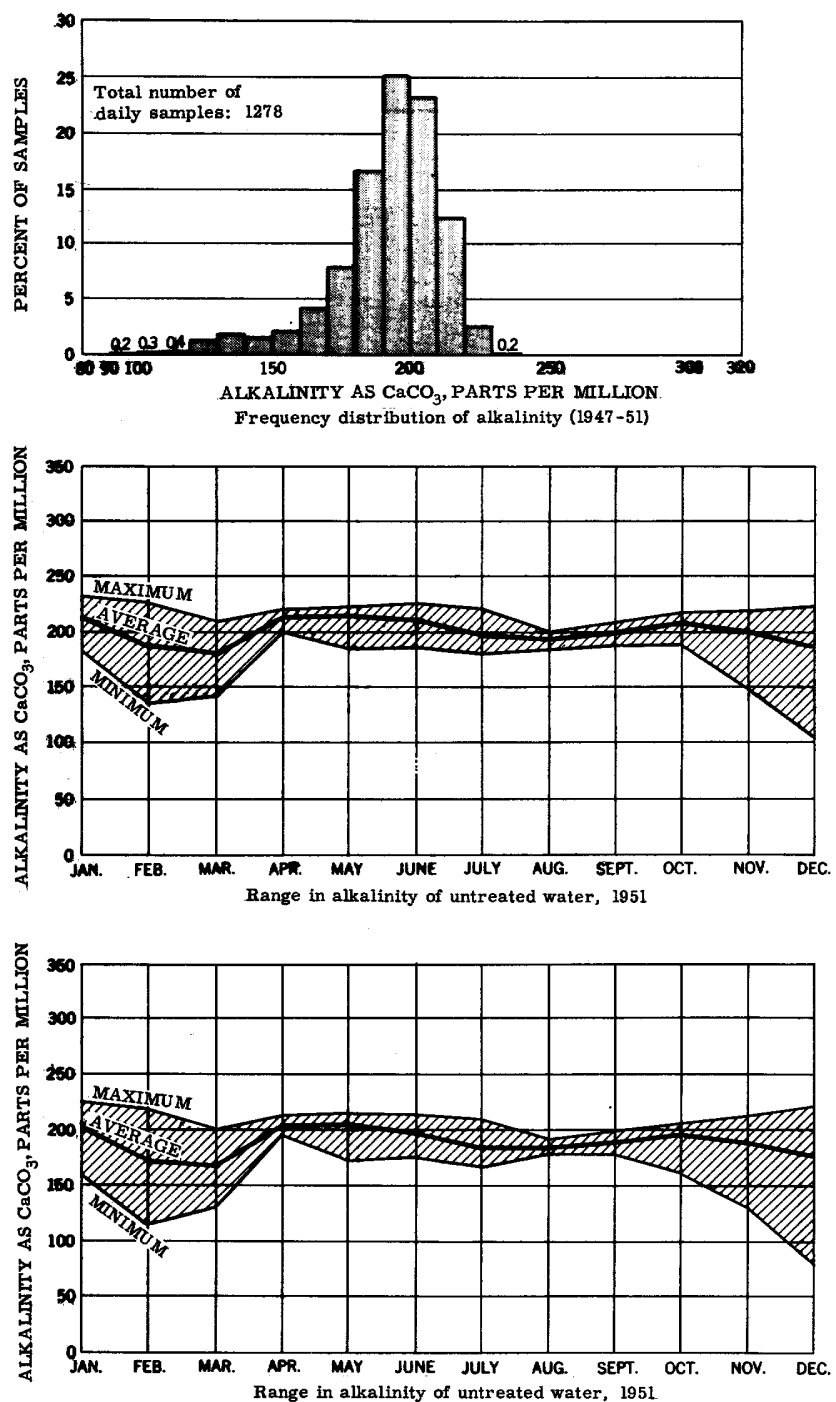

Figure 23. - Alkalinity of water from Fall Creek at Indianapolis. (Data from Laboratory Reports, Indianapolis Water Co.)
The alkalinity of Fall Creek at Indianapolis does not vary as widely as that of the White River. From 1947 to 1951 the alkalinity of Fall Creek water at Indianapolis ranged between 181 and $210 \mathrm{ppm}$ for 65 percent of the time. (See figure 23.)

\section{$\underline{\text { Eagle Creek }}$}

Eagle Creek drains an elongated area to the west of the White River from Hamilton County to Indianapolis and enters the White River in southwest Indianapolis below the sewage-treatment plant. Little Eagle Creek joins the stream several miles above the mouth.

\section{Eagle Creek at Indianapolis}

There is a gaging station on Eagle Creek at Nynhurst Drive near the western edge of Indianapolis, and 6 miles above the mouth. Here Eagle Creek drains an area of 170 square miles. The average discharge for water years $1940-51$ is $94 \mathrm{mgd}$ (146 cfs). During August 1941 there were many days when there was no flow.

The flow characteristics are shown by the duration curve of daily flow, figure 18 . The period of record is $1940-51$, but the duration curve has been computed for the period 1930-51 by use of records for nearby stations. Of the gaged tributaries of the White River in the Indianapolis area, Eagle Creek has the greatest variability of flow (the duration curve is the steepest) and the least sustaining base flow from ground-water storage. Therefore it is not as desirable a source for a large water supply as other streams of the same size in the area. Figure 24 shows the discharge available without storage. For example, the discharge during the period 1938-51 was less than $0.005 \mathrm{mgd}$ per square mile for not more than 2 months and the average discharge for a 2 -month period was not less than $0.001 \mathrm{mgd}$ per square mile. Because of low sustained flows, it is probable that storage would be required in order to provide a significant usable supply. A curve of storage required to maintain selected discharges appears in iigure 19.

During March 1913, flood waters reached an elevation of 722.2 feet above mean sea level at Lynhurst Drive, according to information of local residents. Elevations of other recent floods are listed in table 1.

\section{Quality}

Results of a single analysis of water from Eagle Creek are given in table 2. This sample indicates that the water is similar in chemical character to water from the White River; it is a calcium bicarbonate water of moderate mineral content.

\section{Other streams}

Discharge measurements were made on three of the ungaged streams, Lick Creek at the Belmont Avenue bridge, which drains an area of 23 square miles; Pleasant Run at Indiana Route 37 , which drains an 


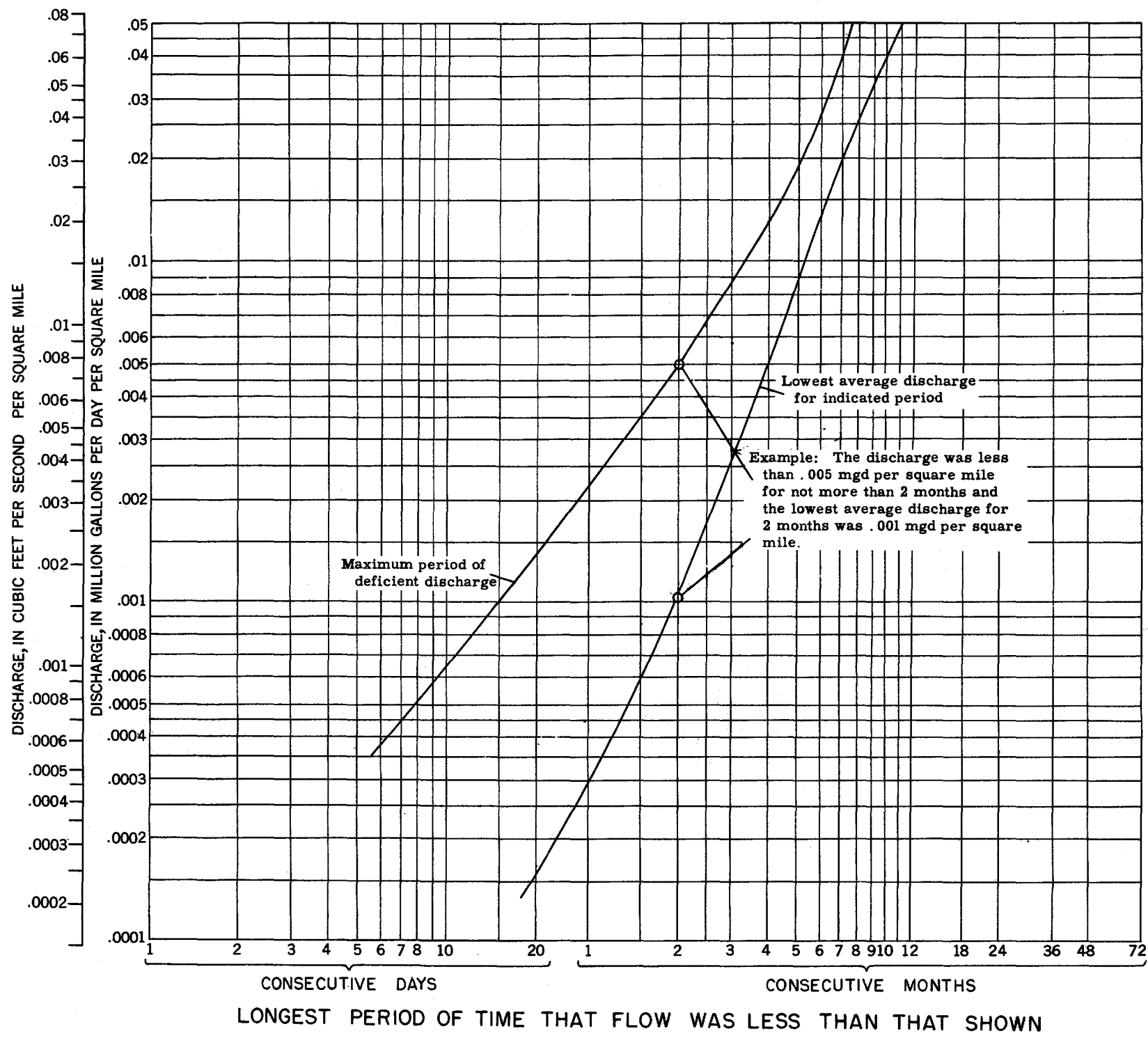

Figure 24. -Discharge available without storage, Eagle Creek at Indianapolis, 1938-51.

area of 21 square miles; and Little Eagle Creek at Washington Street bridge, which drains an area of 27 square miles. Nine discharge measurements were made on each of these streams during the period of low flow of 1952. There was no flow in Pleasant Run part of the time. The discharge measurements were correlated with the 1930-51 discharge of gaged streams in the vicinity.

The approximate low flow characteristics were thus obtained. The following tabulation shows the flow in million gallons per day per square mile for selected percentages of time.

\begin{tabular}{lccc}
$\frac{\text { Percent }}{\text { of time }}$ & $\frac{\text { Pleasant }}{\text { Run }}$ & $\frac{\text { Lick }}{\text { Creek }}$ & $\frac{\text { Little Eagle }}{\text { Creek }}$ \\
\hline $60 \ldots \ldots \ldots \ldots \ldots \ldots \ldots .0 .06$ & 0.16 & 0.04 \\
$70 \ldots \ldots \ldots \ldots \ldots \ldots \ldots$ & .032 & .12 & .013 \\
$80 \ldots \ldots \ldots \ldots \ldots \ldots \ldots$ & .018 & .08 & .004 \\
$90 \ldots \ldots \ldots \ldots \ldots \ldots \ldots$ & .008 & .06 & .001 \\
$95 \ldots \ldots \ldots \ldots \ldots \ldots \ldots$ & .004 & .05 & $\ldots \ldots \ldots$
\end{tabular}

\section{GROUND WATER}

\section{Occurrence}

Ground water is that water which accumulates underground and saturates the openings or spaces between assorted loose rock particles, or between the grains or in crevices in consolidated rocks. It is derived mainly from precipitation that percolates downward into underground reservoirs. Infiltration of precipitation takes place at points or in areas where openings appear in the materials of the land surface.

In the Indianapolis area ground water occurs under both water-table and artesian conditions. Under water-table conditions, the water surface is not confined by an overlying impermeable layer and the water is under atmospheric pressure. The water table is at the top of the zone of saturation. It coincides with the water level in unpumped wells. Under artesian conditions the water is confined between imper- 


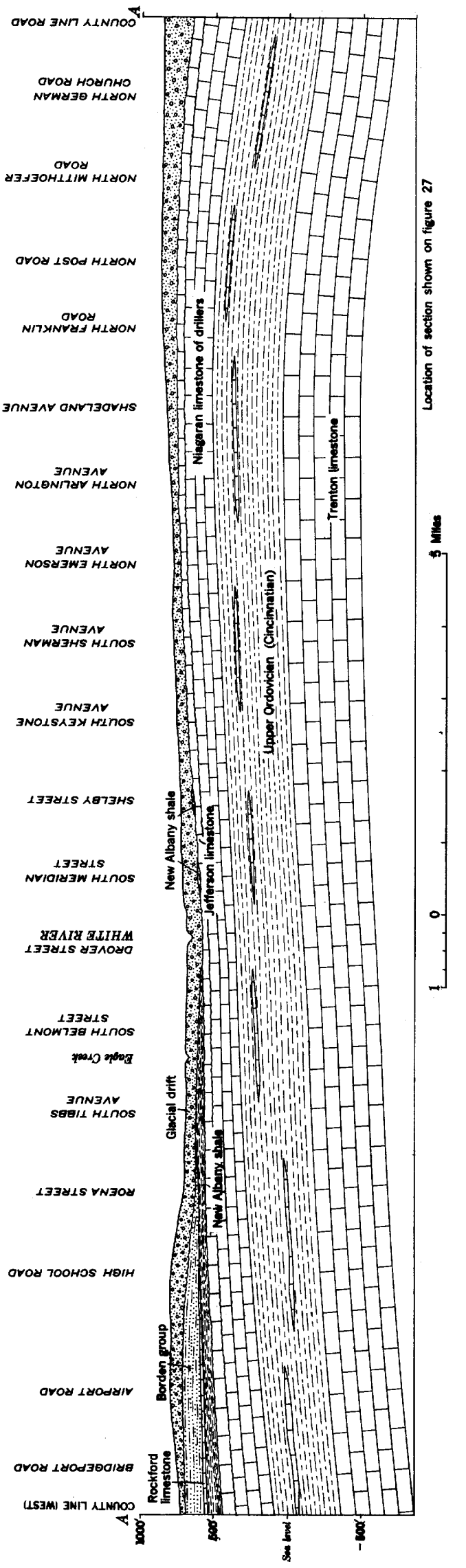

meable layers and is under pressure. The pressure head, or height to which water will rise in unpumped wells, marks the piezometric surface. Water enters artesian aquifers at high levels and may travel considerable distances laterally to low levels.

Water-table conditions are typical of shallow waterbearing sands and gravels underlain by a layer of clay, a hardpan, or dense shale. Artesian water-bearing sands occur in several places under tight glacial till composed of very fine silt and clay. Water under artesian conditions occurs also in fractured and porous zones of the bedrock. The quantity of water that may be contained in a water-bearing rock is dependent upon the porosity which is the ratio of the total volume of openings or spaces in a mass of material to the total volume of such mass, expressed as a percentage. Porosity differences are common and result from differences in shape, arrangement, and the degree of assortment of rock particles. The amount of water that a water-bearing formation will yield is measured by the permeability, which is the characteristic of porous material that allows it to transmit water. The smaller the space, the more restrained the movement of water and the lower the permeability. The characteristic is dependent primarily on the size of the pore spaces in the rock.

A rock formation or group of rock formations that transmits water in sufficient quantity to support wells or springs is called an aquifer. The quantity of water that flows or is pumped from an aquifer is the discharge. Replacement is accomplished as water percolates into an aquifer or is renewed by recharge. In an aquifer variable quantities of water are stored. The storage capacity is related to permeability and size of aquifer. The quantity of water in storage is reduced when the discharge (outflow) is greater than recharge (inflow). Discharge can continue only as long as there is water in storage. Under natural conditions the rate of movement of ground water from areas of recharge toward areas of discharge may be as little as a few feet a year or as much as several feet a day. Thus, the movement is very slow.

\section{Water-Bearing Formations}

In the Indianapolis area the principal sources of ground water are the variable and widely scattered sand and gravel deposits of the Pleistocene, the Jeffersonville limestone of Middle Devonian age and the Niagaran limestone of drillers of Silurian age. The character and water-bearing properties of these rock formations as found in Marion County are given in the chart of rock formations given below. The general geologic features are shown in figure 25 . 


\begin{tabular}{|c|c|c|c|c|c|}
\hline 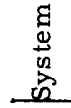 & Series & $\begin{array}{l}\text { Group } \\
\text { or } \\
\text { formation }\end{array}$ & $\begin{array}{c}\text { Thickness } \\
\text { (feet) }\end{array}$ & Character & Water-bearing properties \\
\hline \multirow[b]{2}{*}{ 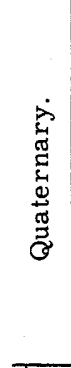 } & Recent. & Alluvium. & $0-40$ & $\begin{array}{l}\text { Alluvium made up of clay, silt, and fine sand } \\
\text { in bottom lands; fine to coarse sands and fine } \\
\text { gravel in channel deposits. }\end{array}$ & $\begin{array}{l}\text { Permeable sands and gravels, thin, lenslike, and restricted } \\
\text { in areal extent. Water yield and rate variable. Chemical } \\
\text { quality and temperature variable with contamination likely } \\
\text { during floods. }\end{array}$ \\
\hline & $\begin{array}{l}\text { Pleisto- } \\
\text { cene. }\end{array}$ & Glacial drift. & $15-260$ & $\begin{array}{l}\text { Drift composed of mixtures of clay, sand, gravel } \\
\text { and boulders as till; assorted and bedded sands } \\
\text { and gravels as outwash. }\end{array}$ & $\begin{array}{l}\text { Shallow sandy and gravelly till of rather low permeability, } \\
\text { yields are small to moderate; water-table conditions; good- } \\
\text { quality water. Deeper sands and gravels, under artesian } \\
\text { pressure; variable in permeability, yield, and quality of } \\
\text { water. Outwash deposits, higher in permeability, yields } \\
\text { moderate to large. Water-table and artesian conditions } \\
\text { occur. Chemical quality and temperature more uniform. }\end{array}$ \\
\hline \multirow{2}{*}{ 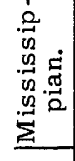 } & & Borden group. & $0-85$ & $\begin{array}{l}\text { Silts tones and shales, thin bedded and } \\
\text { alternating. }\end{array}$ & $\begin{array}{l}\text { Permeability low, rocks fine grained and generally imper- } \\
\text { vious; quantity of water small and quality poor. }\end{array}$ \\
\hline & & $\begin{array}{l}\text { Rockford lime - } \\
\text { stone. }\end{array}$ & $0-4$ & Limestone, clayey, thin-bedded. & Too thin for water in quantity. \\
\hline \multirow{2}{*}{ 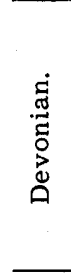 } & Upper. & $\begin{array}{l}\text { New Albany } \\
\text { shale. }\end{array}$ & $0-150$ & $\begin{array}{l}\text { Shale, black, gray, and brown, top part usual- } \\
\text { ly fractured and soft, locally very thin. }\end{array}$ & $\begin{array}{l}\text { Permeability low, water obtained from fractures, unreliable } \\
\text { in quantity and chemical quality. Shale when present be- } \\
\text { tween glacial overburden and underlying limestone re- } \\
\text { stricts ground-water movement. }\end{array}$ \\
\hline & Middle. & $\begin{array}{l}\text { Jeffersonville } \\
\text { limestone. }\end{array}$ & $40-60$ & $\begin{array}{l}\text { Limestone, white to gray, thin-bedded, frac- } \\
\text { tured, upper part soft and porous, lower } \\
\text { part harder and denser. }\end{array}$ & $\begin{array}{l}\text { Permeability variable, usually not high, many fractures and } \\
\text { solution channels occur, yields small to large, water under } \\
\text { artesian pressure; water is potable, having a moderate } \\
\text { range in dissolved solids. }\end{array}$ \\
\hline 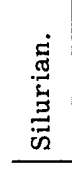 & Middle. & $\begin{array}{l}\text { Niagaran lime- } \\
\text { stone of } \\
\text { drillers. }\end{array}$ & $150-300$ & $\begin{array}{l}\text { Limestone, blue to buff, massive, crystalline; } \\
\text { dolomitic in part, containing porous zones } \\
\text { and is slightly fractured. }\end{array}$ & $\begin{array}{l}\text { Permeability variable, this limestone and the one above con- } \\
\text { sidered one hydrologic unit, yields small to moderate ex- } \\
\text { cept in White River valley where they are high; water under } \\
\text { artesian pressure; water is potable, having a moderate } \\
\text { range in dissolved solids. }\end{array}$ \\
\hline \multirow{3}{*}{$\begin{array}{l}\frac{0}{0} \\
\stackrel{0}{0} \\
\stackrel{0}{0} \\
0 \\
0 \\
0\end{array}$} & $\begin{array}{l}\text { Upper } \\
\text { (Cincin- } \\
\text { natian). }\end{array}$ & & $500-600$ & $\begin{array}{l}\text { Shale, blue to green and thin-bedded blue lime- } \\
\text { stone in upper part; brown to black, fine- } \\
\text { grained shale in lower part. }\end{array}$ & $\begin{array}{l}\text { Permeability low, serves as lower confining layer of lime- } \\
\text { stones above, not a water source. }\end{array}$ \\
\hline & \multirow{2}{*}{ Middle. } & $\begin{array}{l}\text { Trenton lime - } \\
\text { stone. }\end{array}$ & 500 & $\begin{array}{l}\text { Limestone, massive, bedded, predominantly } \\
\text { dolomitic. }\end{array}$ & $\begin{array}{l}\text { Permeability lower than above limestones, large quantities of } \\
\text { mineralized water in storage, under artesian pressure, not } \\
\text { considered potable. }\end{array}$ \\
\hline & & $\begin{array}{l}\text { St. Peter } \\
\text { sandstone. }\end{array}$ & $\begin{array}{l}\text { Not } \\
\text { known. }\end{array}$ & Sandstone, fine-grained, uniform, porous. & $\begin{array}{l}\text { Permeability good for deeply buried sandstone, water under } \\
\text { artesian pressure, large quantities in storage, highly min- } \\
\text { eralized, not potable; has been used as a mineral water. }\end{array}$ \\
\hline
\end{tabular}




\section{Consolidated Rocks}

Consolidated rocks (bedrock) do not crop out at the surface anywhere in the Indianapolis area. They are concealed by a mantle of glacial drift of variable thickness. Comparisons of elevations above mean sea level of the bedrock surface with those of the present land surface discloses two important conditions: in many places differences in present topography are not related to differences in relief on the underlying bedrock surface and there are buried valleys in the area. The minimum depth to bedrock occurs in the northern part of Indianapolis in the Broad Ripple section, at 65th Street and College Avenue. Here the top of the limestone is at an elevation of about 690 feet above mean sea level and is only 15 feet below the land surface. Depths to bedrock surface of less than 25 feet have been found at several places beneath the flood plain of the White River above Fall Creek. These bedrock highs do not coincide with land-surface highs.

Land surface to the northeast and southeast is generally at higher elevations than within the city. At Oaklandon, to the northeast, bedrock depths range from 112 feet to more than 320 feet below land surface. The land surface is rather flat with not more than a range of about 20 feet. Where the bedrock is deepest its top lies between 530 and 550 feet above mean sea level.

Southeast of the city and south of New Bethel, depths to bedrock in excess of 200 feet have been recorded; the maximum known is 257 feet. Here the limestone is at an elevation of about 600 feet above mean sea level.

The above information and similar data from many other places are strong evidence of buried valleys. These buried valleys are remnants of a drainage developed on a former land surface. This land surface must have been modified somewhat by the Pleistocene glaciation before being filled in and covered over by glacial drift.

The bedrock surface is composed of rocks of Middle and Late Devonian and early Mississippian ages. The principal regional dip of the strata is to the southwest, so that from northeast to southwest progressively younger rocks occur (fig. 25).

Long before the application of the protective veneer of glacial drift, these tilted rock formations had been worn down to a nearly level surface. This surface was later uplifted in such a manner as to permit dissection and the development of more than 200 feet of changes in relief by differential erosion of formations that differed in resistive properties.

The Jeffersonville or "Corniferous" limestone of Middle Devonian age is the oldest rock that is definitely recognized in this bedrock surface in the area. Beneath the Jeffersonville limestone lies the Niagaran limestone of drillers of Middle Silurian age. Nowhere in the county, so far as is known does the Niagara reach the bedrock surface.

Very few wells obtain water from formations below the Niagaran limestone of drillers. Oil test wells have been drilled into the underlying Ordovician rocks.
These rocks are characterized by a shale in the upper part and underlain by the massive Trenton limestone and the porous St. Peter sandstone, both of which contain highly mineralized water.

The Niagaran limestone of drillers is an important source of water in the eastern half of the area. It is much thicker, harder; and denser than the Jeffersonville limestone above it. Water from the Niagaran limestone is obtained from porous layers and fracture zones. The water is under artesian pressure. The rock, particularly in the uplands, is not very permeable; consequently, there is considerable drawdown in pumped wells.

The Jeffersonville limestone is directly beneath the drift in about one-half of Marion County - the entire northeastern, eastern, and extreme southeastern sections of the county. Within the Indianapolis city limits, it underlies the drift everywhere except in the extreme western part where the overlying New Albany shale appears. The Jeffersonville limestone also is waterbearing. Since neither of the two limestones is exposed at the surface in the vicinity of Indianapolis, the recharge must take place through the glacial overburden that covers them. The recharge is most abundant in the White River and Fall Creek valleys, where the limestone is directly overlain by permeable sand and gravel; it is least abundant in the uplands, where the glacial drift is clayey.

The Jeffersonville limestone is thin bedded and fractured and the top part is usually reported as softer and more porous than the lower part. The yields of the rock wells that have been drilled in this limestone vary with diameter and depth. The artesian head in the limestone and the lower glacial gravel directly above the limestone is reported to be the same. This would make the two water-bearing materials of different geological origin and character a single hydrologic unit. Therefore, extensive pumping from the lower gravels has affected the head in the Jeffersonville limestone. This condition was recognized by some drillers and well users in the early stages of the development of water from the Jeffersonville limestone. Locally this limestone is a good producer of water and in some areas it is the best source of ground water. These areas include the eastern part of the county where the glacial drift, though thick, is clayey; and areas in the White River valley where the limestone is even more productive than the permeable glacial outwash gravel above it.

In downtown Indianapolis and the surrounding industrial areas, drilled wells derive water from both limestone formations which make it difficult to ascertain relative yields and long-term production characteristics of each limestone. Years of heavy pumping have caused substantial declines in water levels in these limestones. Reduced yields from limestone wells have been reported by the users of large quantities of water from these sources.

The contact of the Jeffersonville limestone with the New Albany shale lies near the western boundary of Indianapolis and extends in an arc around the south end of the city and then diagonally to the southeast corner of the county. This shale underlies the drift in the western and southern parts of the county, except 
for a small triangular section in the extreme southwest corner. The shale caps the underlying limestone and has a tendency to prevent free movement of water into it. Along its eastern boundary the shale is thin and perhaps fractured, thus permitting some water to move from the glacial overburden into the underlying limestone.

In a small triangle in the extreme southwest corner of the county the bedrock immediately beneath the drift consists of siltstone, shale, and limestone of early Mississippian age. These rocks are thin bedded, fine grained, and of very low permeability. They are known to yield very small quantities of water to wells in Marion County.

\section{Glacial Deposits}

The glacial drift in Marion County and surrounding areas is attributed to two stages of glaciation, the Illinoian and Wisconsin. The Illinoian drift is the older and is covered by the younger Wisconsin drift. The drift was deposited by ice masses that contained within them large boulders and quantities of sand, gravel, and clay derived from regions over which they had moved prior to melting. Most of these drift deposits consist of till, an unassorted heterogeneous aggregation of boulders, gravel, and sand held together in a clay matrix. In some places the material was sorted by flowing melt water. Water-laid clay, sand, and gravel beds occur as terrace and outwash deposits and as lenses in the till. In some places, extensive, thick beds of sand and gravel occur in the buried valley and deep drift sections of the region.

The younger (Wisconsin) drift cannot be distinguished from the older (Illinoian) drift by any single characteristic feature. The Illinoian drift is composed of a compact yellow to blue stony clay and thin beds of sand and gravel. The larger rock particles in this drift are generally decayed. Lime and iron were largely leached from the upper layers prior to burial by the later Wisconsin drift. A hard layer of indurated stony clay or hardpan of ten separates these two drift sheets in and around Indianapolis. Topographic expression is mainly the result of deposition of the Wisconsin drift. Low morainic ridges and knolls with till plains behind them and outwash deposits of sands and gravels heading in them are the major features of the Wisconsin drift.

The greater part of Marion County is a till plain. The till is predominantly clayey, but thin beds of sand and gravel are interspersed within it. Its permeability is relatively low so that water entering it moves very slowly to the water-bearing sand and gravel lenses. Therefore, in most places only small quantities of water are available from these thin interbedded waterbearing sands and gravels. In a few places, however, wells yield large supplies from sand and gravel in the till and associated morainic deposits.

Shallow wells are common in the till. Their yields are variable, and they are the first to go dry in dry weather. In the outlying suburban and farm or rural areas the dug well has been gradually replaced by the driven well for tapping deeper water-bearing gravels. Shallow water in the till usually occurs under watertable conditions and the rise and decline of the water level is in response to seasonal changes in precipitation.
Extensive gravel deposits are found on both sides of the White River north of the city from Broad Ripple to the northern boundary of the county. Similar deposits occur on the east side of Eagle Creek at Speedway City and on the west side of the White River to beyond the southern boundary of Marion County.

Outwash gravel extends along the east side of White River south from the city limits into Johnson County. A prominent valley begins northeast of Fort Benjamin Harrison and widens out until it joins the White River valley. This valley is occupied by Fall Creek. A valley fill, consisting mainly of sand and gravel, extends to a depth of 100 feet or more over a wide area. In sections of this valley the Wisconsin till is thought to be absent and a weathered clay till that is probably of Illinoian age is found beneath gravel terrace deposits. Extensive gravel terrace deposits are characteristic of the east bank of the White River and the city of Indianapolis was built on them.

Ground-water withdrawal is greater from the outwash deposits and the valley fill of the White River and tributary valleys than from all remaining ground-water sources. Industries using large quantities of water have constructed and developed tubular and gravelpacked wells in these excellent water-bearing deposits. Geologic and hydrologic conditions are favorable to abundant recharge and a sustained supply.

The upper sand or first water-bearing sand was never a good producer. It is too thin, lacks continuity, and is easily polluted and readily depleted of its stored water. Underneath the first sand there is generally a hardpan or claypan layer. Beneath this dense layer there are at least two and in places as many as four water-bearing gravel beds which are the source of water for many of the gravel wells of Indianapolis. They are separated from one another by hardpan or clay, but there is no evidence that the separation is extensive; on the contrary, it is believed that the beds are interconnected in many places and function more or less as a hydrologic unit. Water from these beds is under artesian pressure in most places, but they are accessible to recharge as shown by the fact that by far the greatest part of the water pumped from them to date has been replenished. The heads in these lower gravels and in the underlying limestone are very similar.

\section{Alluvial Deposits}

Recent alluvium is present in the bottoms of the White River, Fall Creek, and Eagle Creek. It consists of a thin veneer of silt, sand, and gravel.

Although the alluvium is not an important water bearer, infiltration of river water through the alluvium to the underlying water-bearing gravels may be induced by pumping of wells located near the river. Whenever induced infiltration occurs the water produced is a mixture of ground water and surface water.

\section{Changes in Ground-Water Levels}

Ground-water levels rise and fall in response to changes in rate and distribution of recharge and discharge (fig. 26). 


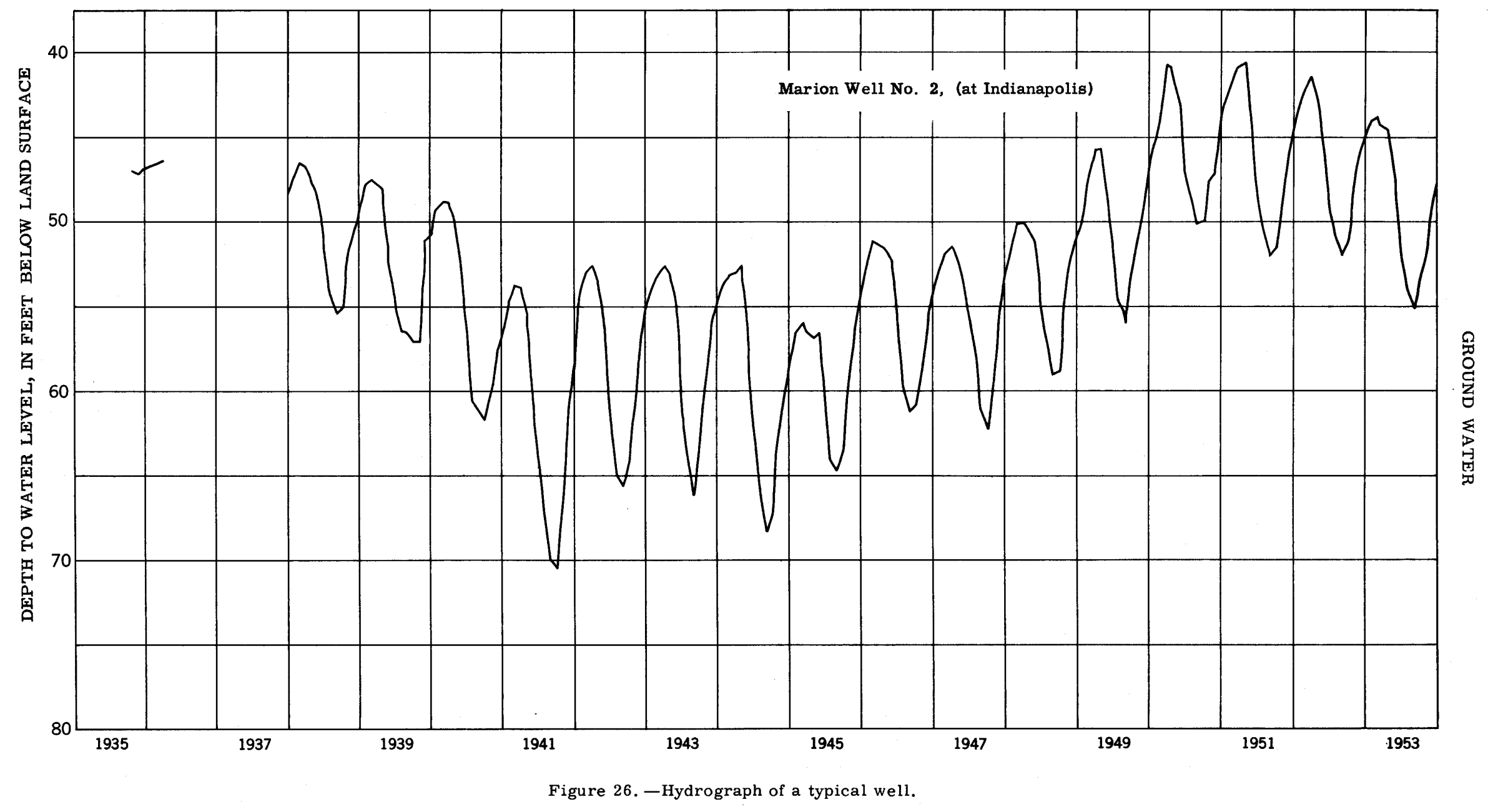


Under water-table conditions a change in water levels indicates a change in the quantity of water in storage. Water levels decline when discharge is greater than recharge and rise when discharge is less than recharge.

The ground-water reservoirs are recharged naturally by infiltration of precipitation (fig. 26). The groundwater reservoirs could also be recharged artificially by the use of spreading grounds or pits or by injecting water into them through recharge wells, although such practices are not being followed at present in the area. Discharge is artificial, such as from pumped wells, or natural, such as the flow from springs or seeps. Under certain conditions water may flow from one aquifer into another.

Ground water moves by gravity down the hydraulic gradient, from points of high to low pressure head. When a well is pumped the water table in the immediate vicinity of the well is lowered, forming a cone of depression. Lowering the water level in the vicinity of the well increases the hydraulic gradient and, therefore, increases the flow toward the well. If the well is pumped at a constant rate the water level in the vicinity of the well will decline until a balance is established between discharge from the well and flow toward the well.

In large cities, such as Indianapolis, there are usually local concentrations of industry. As the use of water from wells by these industries increases, the cones of depression of the wells enlarge and in places overlap, causing interference. This condition is attended by progressive declines in water levels and is most pronounced in the areas of heaviest pumping.

Under artesian conditions a change in the piezometric surface indicates a change in pressure; the change in storage usually is relatively small. The water levels in artesian wells respond to change in barometric pressure. Water under artesian conditions also moves down gradient, from areas of high head to areas of low head, and pumping a well produces a cone of depression in the piezometric surface. However, under artesian conditions the cone of depression increases in size at a much more rapid rate than under water-table conditions and will extend much farther before a balance is reached between inflow and outflow. Therefore, with similar withdrawal and spacing of wells, artesian wells will show mutual interference sooner than will water-table wells.

Periodic lowering of water levels is not conclusive evidence of overpumping, but continual decline over a long period is an indication of either increasing pumping or overpumping. If the pumping remains about constant and the water levels decline over a long period, overpumping is indicated.

\section{Wells}

Three principal types of wells are used in the Indianapolis area - dug or bored, driven, and drilled wells.

Dug and bored wells are used where the water table is close to the surface. In the early days of Indianapolis the dug well with its hand pump could be found everywhere and today it is still common in rural areas. Later, many bored wells were put down.

As the population of Indianapolis grew, and the quantity of water withdrawn was increased, the water level in the more heavily pumped areas was lowered to depths greater than could readily be reached by digging. Driven wells were then put down in many places where conditions were favorable. The driven well could tap the previously untapped sand and gravel below the first clay layer. The water from the aquifer below this clay rose to within several feet of the surface or flowed. These wells were cased and thus shut out the shallow water, which had become contaminated.

Drilled wells are used to tap the deeper waterbearing zones of the glacial drift and the bedrock. Yields from these wells are variable, but those of wells in the bedrock generally are smaller than those of wells in the sands and gravels. Most drilled wells are put down by the cable-tool method, but a few of the larger diameter wells have been put down by the rotary method or by means of the clamshell or orangepeel bucket.

There is one collector-type well in the Indianapolis area. It consists of a caisson with projecting horizontal screens. This type of well is most suited for obtaining water by induced infiltration in areas adjacent to streams or large lakes. Well losses and drawdowns are reduced by the long projecting screens, which tap long horizontal sections of the aquifer parallel to or beneath the infiltration sources. The water from this type of well is a mixture of ground and surface water and, therefore, its physical and chemical quality depends on the quality of both the surface and ground water and the proportion drawn from each source.

In downtown Indianapolis many of the older industrial wells use two or more water-bearing beds as the water source. Thus waters of different chemical quality and temperature and under slightly different pressures are mixed to the extent that it is difficult to determine which quality characteristics belong to each aquifer and its water.

Yields of wells throughout the area range from a few gallons a minute to as much as $3,000 \mathrm{gpm}$ depending upon locality, source, and well construction. Wells in the upper part of the drift on the till plain generally have small yields. Wells in the sand and gravel beneath the clay of the drift on the uplands may yield as much as several hundred gallons a minute. The sand and gravel of the alluvial terraces and outwash along the east side of the White River have produced from a few hundred to $3,000 \mathrm{gpm}$ to large-diameter industrial wells within the city of Indianapolis. Locally, high production from the underlying rock has been reported. Several rock wells close to the White River yielding $1,000 \mathrm{gpm}$ have been developed. It is probable that these wells obtain part of their water directly or indirectly from gravel overlying the limestone.

In cities, such as Indianapolis, where continued expansion of ground-water use and localized overpumping are found, water for air-conditioning use is a problem. Ground water is preferred because it is relatively uniform in temperature and quality. 


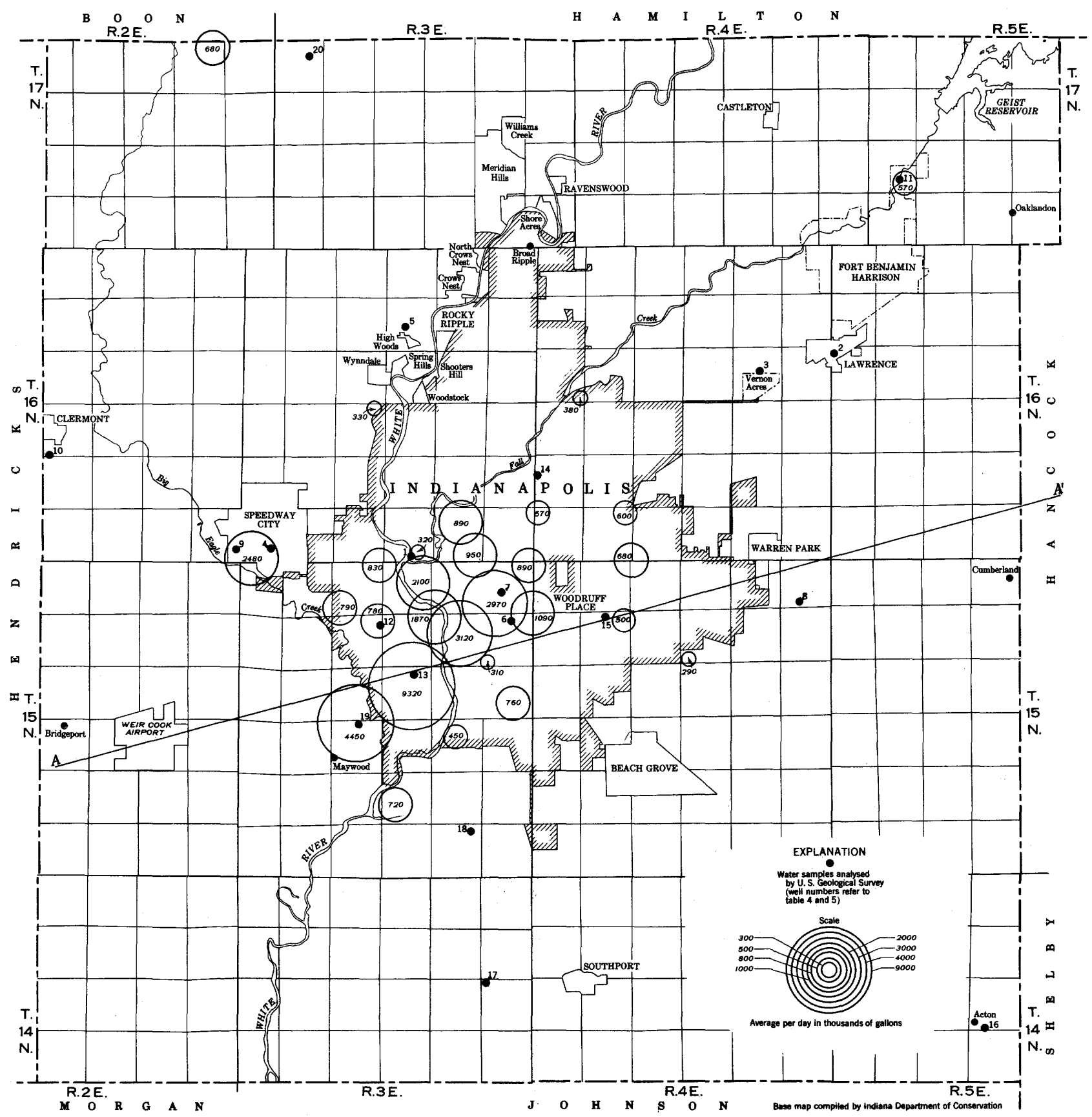

5 mins

Figure 27. - Ground-water sampling sites and ground-water pumpage.

Formerly large withdrawals of ground water for air conditioning depressed the water levels and brought about the installation of several return or recharge wells, especially in the downtown area. None of these recharge wells are in operation at present. Today the use of ground water for air conditioning is chiefly by large industrial plants and a few commercial establishments. Water is wasted to the sewers. The cheaper surface-water sources, cooling towers, and recirculation of water have brought about this change.

\section{Quality of Ground Water}

The ground water in the Indianapolis area is quite ate, but some water contains significant proportions of magnesium and sodium sulfates. Iron is found in all the ground water of the area, sometimes in amounts that could be troublesome for some uses. Manganese is not as generally present, but it has been reported in the water from some wells. The concentration of chloride is low to moderate. Nitrate is present only in small amounts. The fluoride content of the ground water. ranges from trace amounts to $1.4 \mathrm{ppm}$ in the analyses reported. Hydrogen sulfide is commonly present in the ground water of the area, particularly in water from the limestones.

The ranges of concentration of dissolved solids and hardness are wider than is shown in the detailed anal- 
that the hardness or dissolved solids content is seldom much less than the minimum values reported in tables 4 and 5, but the maximum values for ground water in this area may be appreciably greater than shown in these tables.

The concentration of calcium plus magnesium and of sulfate varies directly with the concentration of dissolved solids, whereas the concentration of bicarbonate varies inversely with the concentration of dissolved solids. The chloride content also varies directly with the dissolved solids, although the extent of the variation is not nearly so great as the variation in sulfate content. Increase in dissolved-solids content seems to be due primarily to an accession of calcium and magnesium sulfate and sometimes sodium sulfate. A general classification of 18 samples of ground water from the Indianapolis area is shown in diagrammatic form in figure 28. For all samples calcium and magnesium were more than 70 percent of the total cations

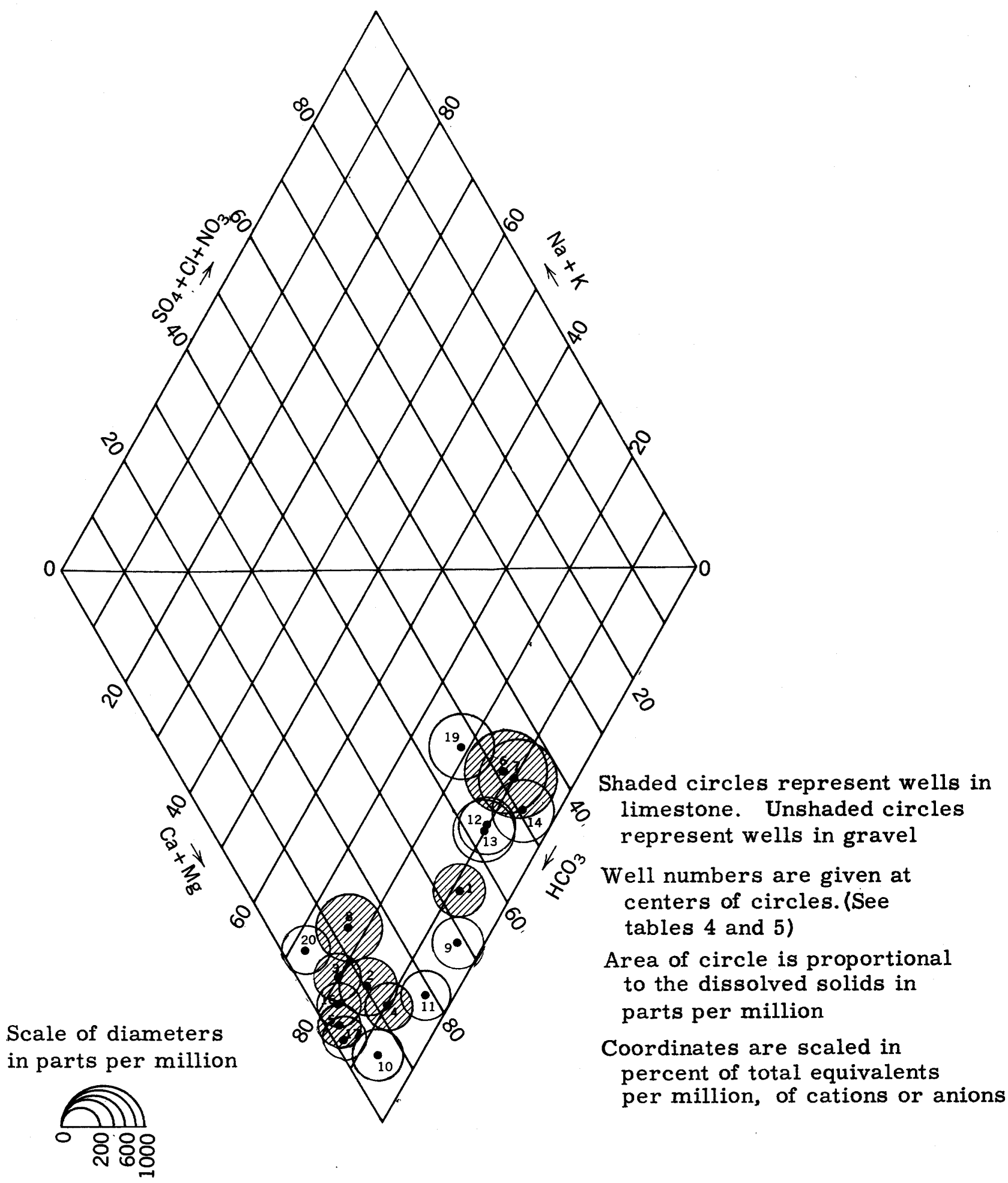


Table 4. - Chemical analyses, in parts per million, of selected ground waters collected in February 1953, in the Indianapolis area

\begin{tabular}{|c|c|c|c|c|c|c|c|c|c|c|c|c|c|c|c|c|c|c|}
\hline \multirow{2}{*}{$\begin{array}{l}\text { Well } \\
\text { no. }\end{array}$} & \multirow{2}{*}{$\begin{array}{l}\text { Water } \\
\text { temper- } \\
\text { ature } \\
\left({ }^{\circ} \mathrm{F}\right)\end{array}$} & \multirow{2}{*}{$\begin{array}{l}\text { Silica } \\
\left(\mathrm{SiO}_{2}\right)\end{array}$} & \multirow{2}{*}{$\begin{array}{l}\text { Iron } \\
(\mathrm{Fe}) \\
\text { total }\end{array}$} & \multirow{2}{*}{$\begin{array}{l}\text { Man- } \\
\text { ga- } \\
\text { nese } \\
\text { (Mn) } \\
\text { total }\end{array}$} & \multirow{2}{*}{$\begin{array}{l}\text { Cal- } \\
\text { cium } \\
\text { (Ca) }\end{array}$} & \multirow{2}{*}{$\begin{array}{l}\text { Mag- } \\
\text { nesium } \\
(\mathrm{Mg})\end{array}$} & \multirow{2}{*}{$\begin{array}{l}\text { So- } \\
\text { dium } \\
\text { (Na) }\end{array}$} & \multirow{2}{*}{$\begin{array}{l}\text { Po- } \\
\text { tas - } \\
\text { sium } \\
(\mathrm{K})\end{array}$} & \multirow{2}{*}{$\begin{array}{l}\text { Bicar - } \\
\text { bonate } \\
\left(\mathrm{HCO}_{3}\right)\end{array}$} & \multirow{2}{*}{$\begin{array}{c}\text { Sul- } \\
\text { fate } \\
\left(\mathrm{SO}_{4}\right)\end{array}$} & \multirow{2}{*}{$\begin{array}{c}\text { Chlo- } \\
\text { ride } \\
\text { (Cl) }\end{array}$} & \multirow{2}{*}{$\begin{array}{l}\text { Fluo- } \\
\text { ride } \\
\text { (F) }\end{array}$} & \multirow{2}{*}{$\begin{array}{c}\mathrm{Ni}- \\
\text { trate } \\
\left(\mathrm{NO}_{3}\right)\end{array}$} & \multirow{2}{*}{$\begin{array}{c}\text { Dissolved } \\
\text { solids } \\
\text { (residue } \\
\text { on evap- } \\
\text { oration } \\
\text { at } 180^{\circ} \mathrm{C} \text { ) }\end{array}$} & \multicolumn{2}{|c|}{$\begin{array}{l}\text { Hardness } \\
\text { as } \mathrm{CaCO}_{3}\end{array}$} & \multirow{2}{*}{$\begin{array}{l}\text { Specific } \\
\text { conduct- } \\
\text { ance } \\
(\mathrm{micromhos} \\
\left.\text { at } 25^{\circ} \mathrm{C}\right)\end{array}$} & \multirow{2}{*}{$\mathrm{pH}$} \\
\hline & & & & & & & & & & & & & & & $\begin{array}{l}\text { Calcium, } \\
\text { mag- } \\
\text { nesium }\end{array}$ & $\begin{array}{l}\text { Non- } \\
\text { carbon- } \\
\text { ate }\end{array}$ & & \\
\hline \multicolumn{19}{|c|}{ In limestone } \\
\hline$\overline{1}$ & 55 & 9.5 & 1.0 & 0.00 & 93 & 27 & 14 & 1.7 & 304 & 90 & 20 & 0.9 & 3.8 & 419 & 344 & 94 & 666 & 7.2 \\
\hline 2 & 53 & 13 & 1.3 & .00 & 59 & 43 & 25 & 1.3 & 413 & 16 & 7.0 & .9 & 5.5 & 379 & 324 & 0 & 648 & 7.4 \\
\hline 3 & 54 & 14 & 1.0 & .00 & 58 & 37 & 32 & 1.5 & 421 & 10 & 4.5 & 1.0 & 6.5 & 367 & 300 & 0 & 635 & 7.5 \\
\hline 4 & 56 & 16 & 3.0 & .00 & 70 & 25 & 13 & 1.3 & 333 & 22 & 5.9 & .9 & 1.9 & 315 & 280 & 0 & 544 & 7.4 \\
\hline 5 & ............... & 16 & 1.4 & .00 & 60 & 26 & 21 & 1.1 & 368 & .8 & 1.8 & .9 & .3 & 300 & 256 & 0 & 541 & 7. 4 \\
\hline 6 & 59.5 & 18 & 1.4 & .35 & 186 & 58 & 40 & 4.4 & 476 & 319 & 51 & .2 & 1.1 & 946 & 705 & 312 & 1,320 & 7.4 \\
\hline 7 & ............. & 17 & 4.5 & .09 & 154 & 45 & 27 & 3.3 & 366 & 267 & 37 & .2 & .1 & 756 & 570 & 269 & 1,070 & 7. 7 \\
\hline 8 & 54 & 12 & .96 & .00 & 58 & 35 & 38 & 1.5 & 400 & 31 & 4. 2 & .6 & 8.5 & 374 & 290 & 0 & 652 & 7.9 \\
\hline
\end{tabular}

In gravel

\begin{tabular}{|c|c|c|c|c|c|c|c|c|c|c|c|c|c|c|c|c|c|c|}
\hline 9 & 56 & 11 & 0.07 & 0.00 & 101 & 30 & 6.9 & 1.4 & 336 & 92 & 9.0 & 0.1 & 3.7 & 433 & 374 & 100 & 679 & 7.3 \\
\hline 10 & 54 & 20 & 1.0 & .00 & 82 & 27 & 10 & .9 & 389 & 11 & 1.8 & .4 & 3.2 & 337 & 316 & 0 & 583 & 7.2 \\
\hline 11 & 54 & 7.4 & .46 & .00 & 77 & 22 & 5.6 & 1.4 & 289 & 41 & 7. 0 & .1 & .2 & 308 & 282 & 46 & 522 & 7.5 \\
\hline 12 & 57 & 14 & .68 & .00 & 136 & 38 & 23 & 2. 9 & 372 & 194 & 29 & .1 & .2 & 647 & 495 & 191 & 949 & 7. 0 \\
\hline 13 & $\ldots, \ldots, \ldots$, & 13 & 2.0 & .16 & 160 & 39 & 27 & 3.0 & 432 & 217 & 33 & .4 & 1.5 & 734 & 560 & 206 & 1,060 & 6.9 \\
\hline 14 & 52 & 9.7 & 3.4 & .16 & 172 & 41 & 17 & 3.3 & 394 & 261 & 30 & .0 & .0 & 744 & 600 & 275 & 1,080 & 7.4 \\
\hline 15 & 56 & 18 & 1.8 & .08 & 124 & 44 & 21 & 1.5 & 422 & 148 & 22 & .4 & 2.9 & 601 & 490 & 144 & 924 & 7.2 \\
\hline 16 & (................ & 17 & 1.6 & .00 & 61 & 30 & 24 & 1.5 & 388 & 2.9 & 2.4 & 1.4 & 3.5 & 324 & 276 & 0 & 578 & 7.5 \\
\hline 17 & ................... & 14 & 3.0 & .04 & 79 & 17 & 19 & .8 & 376 & 2.9 & 1.4 & .3 & .1 & 296 & 268 & 0 & 546 & 7.6 \\
\hline 18 & ................ & 19 & 1.6 & .00 & 104 & 34 & 7.2 & 1.0 & 426 & 58 & 8.0 & .1 & 1.0 & 431 & 400 & 50 & 725 & 7.2 \\
\hline 20 & ............. & 20 & .54 & .00 & 61 & 25 & 43 & 1.3 & 410 & 7.0 & 1.8 & .8 & 2.0 & 347 & 256 & 0 & 611 & 7. 7 \\
\hline
\end{tabular}


Table 5. - Composition of dissolved solids in selected ground waters

\begin{tabular}{|c|c|c|c|c|c|c|c|c|c|c|}
\hline \multirow[b]{2}{*}{$\begin{array}{l}\text { Well } \\
\text { no. }\end{array}$} & \multirow{2}{*}{$\begin{array}{c}\text { Dissolved } \\
\text { solids } \\
\text { (residue on } \\
\text { evaporation } \\
\left.\text { at } 180^{\circ} \mathrm{C}\right) \\
\text { (ppm) }\end{array}$} & \multicolumn{8}{|c|}{ Percent of dissolved solids ${ }^{\mathrm{a}}$} & \multirow[b]{2}{*}{ Remarks } \\
\hline & & $\begin{array}{l}\text { Cal- } \\
\text { cium } \\
\text { (Ca) }\end{array}$ & $\begin{array}{c}\text { Mag- } \\
\text { nesium } \\
(\mathrm{Mg})\end{array}$ & $\begin{array}{c}\text { So- } \\
\text { dium } \\
(\mathrm{Na})\end{array}$ & $\begin{array}{l}\text { Po- } \\
\text { tas- } \\
\text { sium } \\
(\mathrm{K})\end{array}$ & $\begin{array}{c}\text { Bicar- } \\
\text { bonate } \\
\left(\mathrm{HCO}_{3}\right)^{b}\end{array}$ & $\begin{array}{c}\text { Sul- } \\
\text { fate } \\
\left(\mathrm{SO}_{4}\right)\end{array}$ & $\begin{array}{l}\text { Chlo- } \\
\text { ride } \\
\text { (Cl) }\end{array}$ & $\begin{array}{c}\mathrm{Ni}- \\
\text { trate } \\
\left(\mathrm{NO}_{3}\right)\end{array}$ & \\
\hline \multicolumn{11}{|c|}{ In limestone } \\
\hline 1 & 419 & 23.6 & 6.6 & 3.4 & 0.4 & 36.4 & 21.9 & 4.9 & 0.9 & From both the limestones and gravel; infiltration of river water nct likely. \\
\hline 2 & 379 & 15.7 & 11.5 & 6.1 & .3 & 54.2 & 3.9 & 1.9 & 1.5 & From Devonian and Silurian limestones. \\
\hline 3 & 367 & 15.5 & 9.9 & 8.6 & .4 & 55.6 & 2.7 & 1.2 & 1.7 & From Devonian and Silurian limestones. \\
\hline 4 & 315 & 21.7 & 7.8 & 4.0 & .4 & 50.9 & 6.8 & 1.6 & .6 & $\begin{array}{l}\text { Devonian and Silurian limestones; pumpage in area very heavy; shale thin } \\
\text { and absent in places. }\end{array}$ \\
\hline 5 & 300 & 19.3 & 8.4 & 6.8 & .4 & 58.3 & .3 & .6 & .1 & Devonian limestone; area of very low pumpage. \\
\hline 6 & 946 & 20.4 & 6.3 & 4.4 & .5 & 25.7 & 34.9 & .6 & .1 & $\begin{array}{l}\text { From both limestones; shale reported; contribution from glacial overburden } \\
\text { likely; pumpage forme rly heavy, now much lighter; fluctuations in quality } \\
\text { and temperature. }\end{array}$ \\
\hline 7 & 756 & 21.0 & 6.1 & 3.7 & .4 & 24.5 & 36.3 & 5.0 & .0 & From both the limestones and gravel; in old area of greatest pumpage. \\
\hline 8 & 374 & 15.0 & 9.0 & 9.8 & .4 & 50.9 & 8.0 & 1.1 & 2.2 & Silurian limestone. \\
\hline \multicolumn{11}{|c|}{ In gravel } \\
\hline 9 & 433 & 24.0 & 7.1 & 1.6 & 0.3 & 39.3 & 21.9 & 2.1 & 0.9 & $\begin{array}{l}\text { Shale present, top fractured, contains water; infiltration from Eagle Creek } \\
\text { likely. }\end{array}$ \\
\hline 10 & 337 & 23.5 & 7.7 & 2.9 & .3 & 54.9 & 3.2 & .5 & .9 & $\begin{array}{l}\text { From lower aquifer under hardpan and on top of shale bedrock; well not } \\
\text { affected by nearby wells. }\end{array}$ \\
\hline 11 & 308 & 25.2 & 7.2 & 1.8 & .5 & 46.7 & 13.4 & 2.3 & .1 & From gravels in buried valley. \\
\hline 12 & 647 & 21.9 & 6.1 & 3.7 & .5 & 29.5 & 31.2 & 4.7 & .0 & From combination of gravels and limestones; area of heavy pumpage. \\
\hline 13 & 734 & 22.6 & 5.5 & 3.8 & .4 & 30.0 & 30.6 & 4.7 & .2 & Ranney collector; area of heavy pumpage. \\
\hline 14 & 744 & 23.5 & 5.6 & 2.3 & .5 & 26.5 & 35.7 & 4.1 & .0 & $\begin{array}{l}\text { Limestone hydraulically connected with gravel; area of formerly high } \\
\text { pumpage. }\end{array}$ \\
\hline 15 & 601 & 20.9 & 7.4 & 3.5 & .3 & 35.1 & 25.0 & 3.7 & .5 & Sands and gravels between thick layers of clay. \\
\hline 16 & 324 & 18.2 & 8.9 & 7.1 & .4 & 56.9 & .9 & .7 & 1.0 & Buried valley; water from glacial deposits only; pumpage light. \\
\hline 17 & 296 & 24.5 & 5.3 & 5.9 & .2 & 57.3 & .9 & .4 & .0 & Lower glacial gravel; pumpage very light. \\
\hline 18 & 431 & 23.4 & 7.7 & 1.6 & .2 & 47.3 & 13.1 & 1.8 & .2 & From glacial deposits partly morainic, partly till. \\
\hline 19 & 566 & 18.2 & 5.4 & 7.9 & .6 & 27.5 & 35.0 & 2.9 & .0 & $\begin{array}{l}\text { From lower sand and gravel on top of thin broken Devonian shale; river } \\
\text { infiltration to top part of deposit with slow recharge to lower gravel } \\
\text { likely. }\end{array}$ \\
\hline 20 & 347 & 16.8 & 6.9 & 11.8 & .4 & 55.5 & 1.9 & .5 & .5 & Area of small pumpage. \\
\hline
\end{tabular}

\footnotetext{
${ }^{a}$ Sum of determined constituents used for calculation.
}

${ }^{b}$ Calculated as carbonate. 
and only two samples showed bicarbonate amounting to less than 50 percent of the anions.

The reason for the wide variations in quality of ground water in the Indianapolis area - both from the glacial drift and from the limestones - cannot be determined from the data available. Increased mineralization and fluctuations in quality have occurred in areas of very heavy pumping. Whether this variation is due to movement of water from or through the shales, which are pyritic, is due to gypsum beds (known to be present in the limestone outside the area of this report, but not reported in this area), or is due to more highly mineralized water being drawn from other sources is not known. Whatever the reason for the variation, it seems that gradual increases in the degree of mineralization of the water may be expected at locations where the pumpage is very high over extended periods of time. Infiltration of river water is a possibility at some locations, and almost certainly takes place at times.

\section{Limestone}

Water from the limestone aquifers ranges greatly in quality. The sample from well 5 (tables 4 and 5 ) is from limestone of Devonian age, taken under undis turbed conditions in an area of very low pumpage. This water resembles typical water from the lower gravel containing $300 \mathrm{ppm}$ of dissolved solids and having low sulfate and high bicarbonate. Water from well 8 is from the limestone aquifer of Silurian age. The sample taken from this well contained $374 \mathrm{ppm}$ of dissolved solids and had a low percentage of sulfate and a high percentage of bicarbonate.

Wells 6 and 7 are located in an area where the pumpage has been very high. Samples from these wells had high concentrations of dissolved solids and a high proportion of sulfate and a low proportion of bicarbonate. These wells are in an area where lowered pumping levels, reduced yields, and periodic changes in quality and temperature of water have been reported. The character of water from other wells producing from the limestone is intermediate between these extremes. The typical limestone waters, well 5 (Devonian) and well 8 (Silurian), are very similar, although the water from the older limestone (Silurian) is somewhat more highly mineralized than the water from the younger limestone. (See figure 28.) The typical water from limestone of Silurian age contains a greater proportion of the alkali ions and a smaller proportion of the alkaline earth ions than does water from the limestone of Devonian age.

\section{Glacial Deposits}

Water from the glacial drift also ranges greatly in quality without any apparent relation to the particular horizon from which it is drawn (table 4). Water from well 17, in the southern part of Marion County, is considered representative of water from the lower gravel. A sample of this water contained $296 \mathrm{ppm}$ of dissolved solids, of which 0.9 percent was sulfate and 57.3 percent was bicarbonate (table 5). Pumpage at this location is very light. A sample of water from well 16, in the southeast part of Marion County, contained $324 \mathrm{ppm}$ of dissolved solids and was also low in sulfate and high in bicarbonate. Water from well 20 in the northwestern part of Marion County is taken from the lower part of the glacial drift. A sample of this water had $347 \mathrm{ppm}$ of dissolved solids, was low in sulfate and high in bicarbonate. Here also the area is one of small pumpage. Well 10 draws water from the lower gravel, which here is probably interconnected with other thin sands and gravels at slightly different levels in the bottom of the drift. A sample of this water contained $337 \mathrm{ppm}$ of dissolved solids and was low in sulfate and high in bicarbonate. Pumpage in this area has been moderate.

Water from wells $12,13,14$, and 19 is of a different character than water from wells 10,16, 17, and 20. The concentration of dissolved solids is about twice as great, the percentage of sulfate is much higher, and the percentage of bicarbonate is much lower. The water from these wells is taken from the lower gravel in areas where the gravel is hydraulically connected with the limestone. Pumpage at this location has been very high.

Other wells in the glacial drift produce water intermediate in character between the two types described above. A sample from well 15 has been reported to be characteristic of the middle gravel separated by clays from overlying and underlying gravel deposits. A sample of water from this well contained $601 \mathrm{ppm}$ of dissolved solids, 25.0 percent of which was sulfate and 35.1 percent was bicarbonate. Little, if any, of this water is being contributed directly by the shale or the limestone. The well is close to an area of recent heavy withdrawal. An analysis made in 1945 showed the water from this well to be of the same quality as was reported in the 1953 analysis. The analyses of water from the gravels are also plotted on figure 28 . There is a very high degree of chemical uniformity between water from the limestones and water from the gravels at all concentrations of dissolved solids. It is evident from the characterization in figure 28 that in most cases it would be impossible to distinguish between waters from the various aquifers, on the basis of any of the factors that have been investigated to date.

\section{Temperature}

The year-round natural temperature of ground water is more uniform than that of surface water. There is close correspondence between the natural temperature of ground water and the mean air temperature. In the Indianapolis area the mean air temperature is about $53^{\circ} \mathrm{F}$ and the observed average ground-water temperature is between $52^{\circ}$ and $54^{\circ} \mathrm{F}$.

In the downtown area of Indianapolis the temperature of the shallow water is higher than that of the deeper water at the present time. This is the reverse of a natural condition. Heat losses to the ground from buildings have produced higher ground temperature. Industrial and commercial plants discharge large quantities of warm water to leaky sewers which in turn discharge to the shallow ground-water aquifers. Some warm water has been returned underground by means of recharge or return wells at places where ground water was used for air conditioning. During the summer the volume of water in the White River is generally below average and the temperature of its water is high because of high air temperature. Warm surface 

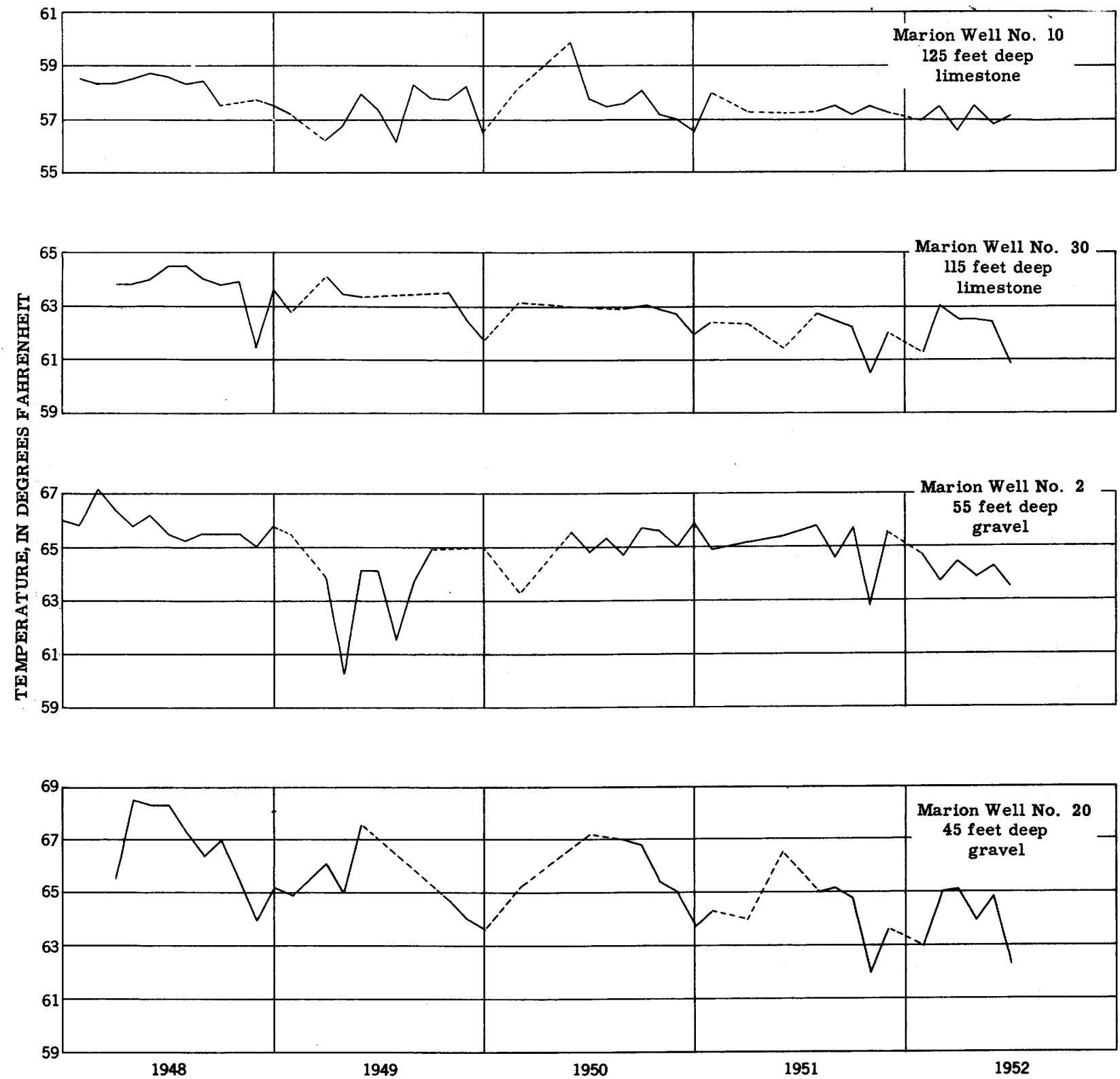

Figure 29. - Temperature of water from four Marion County observation wells, 1948-52.

water may enter depleted ground-water aquifers by infiltration.

In recent years recorded ground-water temperatures in downtown Indianapolis were generally highest in the winter and lowest in the summer. It has also been observed that periodic changes in ground-water levels are followed by local temperature modifications with considerable variation in time lag and magnitude. It is possible that such variations are the result of differences in local pumpage.

Ground-water temperatures in the Indianapolis area have been lower in recent years than formerly (fig. 29). This trend follows a period of rising water levels, reduction in withdrawals of ground water, and almost complete curtailment of the use of recharge wells for air-conditioning water in the downtown area.

\section{PUBLIC WATER SUPPLIES}

The White River and Fall Creek are the major sources of water for public supplies in the Indianapolis area. In 1953 the Indianapolis Water Co. withdrew about $62 \mathrm{mgd}$ from these two sources for this use. All other public water-supply systems in the area used ground-water sources and withdrew a total of about 2 mgd.

\section{Indianapolis Water Co.}

The Indianapolis Water Co. serves about 490,000 people. The water is obtained from the White River, Fall Creek, and wells. Geist Reservoir on Fall Creek has a capacity of 6,900 million gallons. Wells are used only as a standby source. In 1952,65 percent of 
the supply was from the White River, 34 percent from Fall Creek, and less than 1 percent from wells. There are two treatment plants, the White River purification plant and Fall Creek purification plant. Treatment consists of prechlorination, coagulation, sedimentation, filtration, and chlorination. The rated capacity of the two plants totals $98 \mathrm{mgd}$ but they can be overloaded to treat $115 \mathrm{mgd}$. The raw water pumping capacity is $77 \mathrm{mgd}$.

Treated water storage amounts to 26 million gallons, and the pumping capacity for treated water or service pumping capacity is $263 \mathrm{mgd}$. Elevated storage is 3 million gallons; there is no ground storage except for the 23 million gallons at the plants.

Average output in 1953 was $62 \mathrm{mgd}$, average output for highest month was $73 \mathrm{mgd}$ (July), highest day was $94 \mathrm{mgd}$, and the highest hourly rate was $130 \mathrm{mgd}$. In $1953,34.8$ percent of the water was for domestic use, 51.9 percent for industrial and commercial use, and 13. 3 percent was public use and leakage.

Morse Reservoir on Cicero Creek near Noblesville is under construction (1954) and will provide an additional 6,900 million gallons of storage.

Water supplied to consumers in Indianapolis is of fair chemical quality. The water is hard and contains moderate amounts of dissolved solids. The average hardness of treated water for the years 1947-51 ranged from 280 to $305 \mathrm{ppm}$ as $\mathrm{CaCO}_{3}$ at the White River purification plant and from 222 to $251 \mathrm{ppm}$ as
$\mathrm{CaCO}_{3}$ at the Fall Creek purification plant. (See table 6.) The alkalinity as $\mathrm{CaCO}_{3}$ for the same years ranged from 203 to $227 \mathrm{ppm}$ at the White River plant and from 173 to $180 \mathrm{ppm}$ at the Fall Creek plant.

The extremes of alkalinity are much the same as are found in the untreated water. (See figures 15 and 23.) Fluoridation of the supply is practiced. The average daily fluoride concentration for 1951 was $0.76 \mathrm{ppm}$ at both plants. Samples collected on March 28, 1952, contained $1.0 \mathrm{ppm}$ of fluoride.

\section{Other Public Water Supplies}

Five water-supply systems in Marion County furnish water to the public from ground-water sources. The glacial gravels are the chief source of the water. The average daily pumpage for the five systems in 1952 totaled about 2 million gallons. Detailed information on these water-supply systems is given in table 7 .

\section{PRESENT WATER USE}

About $420 \mathrm{mgd}$ was withdrawn from surface- and ground-water sources in 1952 . Of this quantity about $364 \mathrm{mgd}$ was withdrawn from streams and $56 \mathrm{mgd}$ from wells. Most of the water withdrawn was not consumed or evaporated and was, therefore, discharged to the streams after use.

Table 6. Chemical analyses, in parts per million, of the Indianapolis public water supply

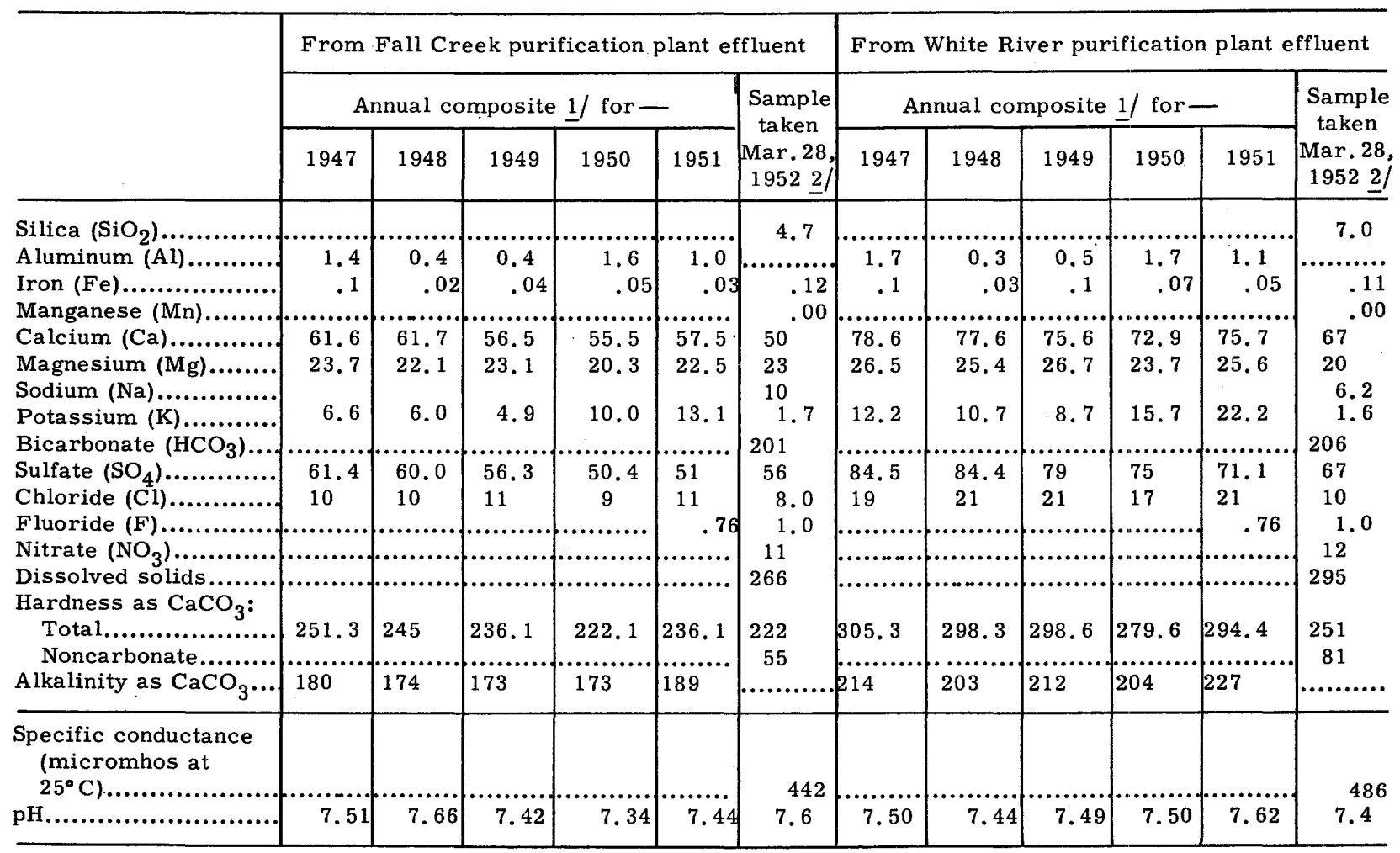

1/Analyses by Indianapolis Water Co. Fluoride, total hardness, alkalinity, and pH results are averages of daily determinations.

2/Analyses by U. S. Geological Survey. 
[Exclusive of Indianapolis]

\begin{tabular}{|c|c|c|c|c|c|c|c|c|c|c|c|}
\hline \multirow{3}{*}{ System } & \multirow{3}{*}{ Ownership } & \multicolumn{6}{|c|}{ WELLS } & \multirow{3}{*}{$\begin{array}{l}\text { Storage } \\
\text { capacity, } \\
\text { thousands } \\
\text { of } \\
\text { gallons }\end{array}$} & \multirow{2}{*}{\multicolumn{2}{|c|}{$\begin{array}{c}\text { Pumpage, } \\
\text { in thousands of } \\
\text { gallons }\end{array}$}} & \multirow{3}{*}{$\begin{array}{l}\text { Popula- } \\
\text { tion } \\
\text { served }\end{array}$} \\
\hline & & \multirow{2}{*}{ Number } & \multirow{2}{*}{$\begin{array}{c}\text { Date } \\
\text { drilled }\end{array}$} & \multirow{2}{*}{$\begin{array}{l}\text { Diameter } \\
\text { (inches) }\end{array}$} & \multirow{2}{*}{$\begin{array}{l}\text { Depth } \\
\text { (feet) }\end{array}$} & \multirow{2}{*}{$\begin{array}{l}\text { Yield } \\
\text { (gpm) }\end{array}$} & \multirow{2}{*}{ Aquifer } & & & & \\
\hline & & & & & & & & & $\begin{array}{l}\text { Avg. } \\
\text { daily }\end{array}$ & $\begin{array}{l}\text { Max. } \\
\text { daily }\end{array}$ & \\
\hline 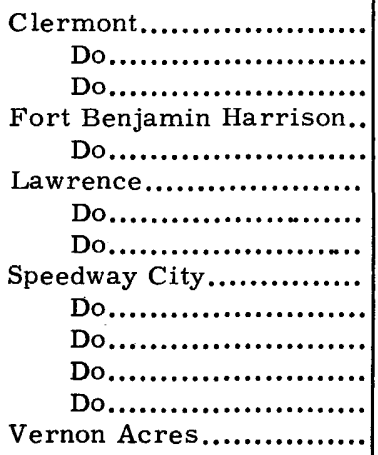 & 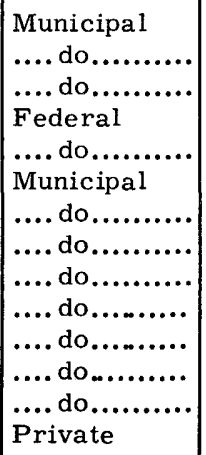 & $\begin{array}{r}\mathrm{a}_{1} \\
1 \\
\mathrm{c}_{1} \\
\mathrm{~d}_{5} \\
3 \\
\mathrm{a}_{1} \\
1 \\
1 \\
\mathrm{a}_{1} \\
1 \\
2 \\
1 \\
1 \\
1\end{array}$ & $\begin{array}{l}1940 \\
1940 \\
1953 \\
1906 \\
1941 \\
1937 \\
1937 \\
\cdots \ldots \ldots \\
1932 \\
1935 \\
1941 \\
1944 \\
1950 \\
1930\end{array}$ & $\begin{array}{c}6 \\
10 \\
26-12 \\
8 \\
12 \\
\ldots \ldots \ldots \ldots \\
10 \\
10 \\
12 \\
50-26 \\
42-18 \\
50-18 \\
42-18 \\
12\end{array}$ & $\begin{array}{l}92 \\
90 \\
72 \\
347-417 \\
80-96 \\
342 \\
385 \\
440 \\
70 \\
77 \\
70-71 \\
120 \\
71 \\
450\end{array}$ & $\begin{array}{c}10 \\
30 \\
160 \\
120-200 \\
400-450 \\
\ldots \ldots \ldots \ldots \\
150 \\
150 \\
350 \\
750 \\
200-300 \\
250 \\
650 \\
90\end{array}$ & 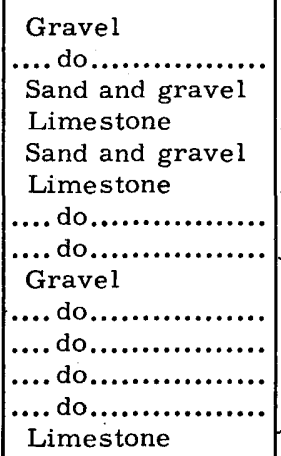 & 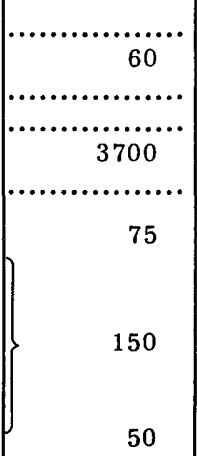 & 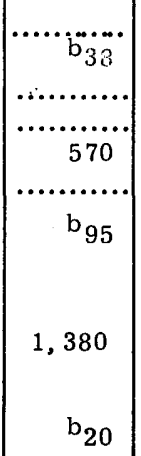 & 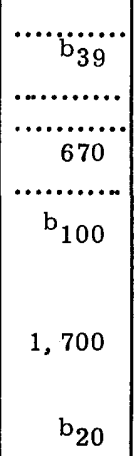 & 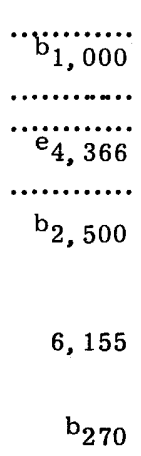 \\
\hline \multicolumn{12}{|c|}{$\begin{array}{l}\text { a Standby use only. } \\
b_{\text {Estimated. }} \\
c_{\text {New well, not in use } 1952 .} \\
d_{\text {Old wells, not in use } 1952 .} \text {. } \\
\text { e Average. }\end{array}$} \\
\hline
\end{tabular}




\section{Surface Water}

The Indianapolis Water Co. obtained $59 \mathrm{mgd}$ in 1952 from surface sources. In 1952, $287 \mathrm{mgd}$ was withdrawn from surface sources for use in generating electric power. Most of this water was used for cooling, and all but $2.4 \mathrm{mgd}$ was returned to the source. An additional $17.8 \mathrm{mgd}$ was withdrawn from the Indianapolis Water Co. canal for industrial use. All except $2 \mathrm{mgd}$ was returned to the canal after use.

\section{Ground Water}

Total use of ground water in the Indianapolis area averaged about $56 \mathrm{mgd}$ in 1952 . However, during hot dry periods in the summer daily withdrawals from all ground-water sources exceed this figure.

Table 8 gives the average daily ground-water pumpage for the years 1942 and 1952 and the areas of concentrated pumpage are shown in figure 27 . There was a reduction in use of the public supply between 1942 and 1952. Most of the 1942 pumpage for public supplies was by the Indianapolis Water Co., but by 1952 this pumpage became negligible. However, there was an increase in average daily pumpage of ground water by other public supply systems. There has been very little change in average daily use of ground water by industry. Decreases in local ground-water use by some industries have been brought about by conversion to or supplemental use of surface water purchased from the Indianapolis Water Co. These decreases have been more than offset by increased use of ground water by several industries and also by an increase in the number of industries.

The increase shown in the remaining use classifications is due primarily to greater per capita consumption of water and more individual water users.

Table 8. - Average daily pumpage of ground water, in millions of gallons per day

\begin{tabular}{|c|c|c|c|c|}
\hline Supply & 1938 & 1940 & 1942 & 1952 \\
\hline Public.... & 1.6 & 5.6 & 5.1 & 2.8 \\
\hline Private: & & & & \\
\hline Industrial. & 33.3 & 38.1 & 38.3 & 39.3 \\
\hline Domestic.. & 2.0 & 2.5 & 3.0 & 5.5 \\
\hline Farm.......... & 3.3 & 4.0 & 3.3 & 1...... \\
\hline Irrigation. & …… & $\ldots \ldots$ & $\ldots \ldots$ & 7.5 \\
\hline Live stock..... & - & ...... & ....... & 1.2 \\
\hline Total.... & 40.2 & 50.2 & 49.7 & 56.3 \\
\hline
\end{tabular}

\section{POTENTIAL SUPPLY}

\section{Surface Water}

The average flow of the White River as it enters the Indianapolis area near Nora is about $700 \mathrm{mgd}$. How ever, the minimum daily flow is only $28 \mathrm{mgd}$. The Indianapolis Water Co. diverts an average of $40 \mathrm{mgd}$ for municipal supply at the Broad Ripple Dam. The availability of water below Broad Ripple Dam varies with the excess of flow over diversion from the White
River and Fall Creek. In order to take advantage of the available surface-water supply in White River and provide a large, dependable supply during periods of drought, storage facilities would be required above Indianapolis. The Indianapolis Water Co. plans to increase the dependable supply in the White River to about $75 \mathrm{mgd}$ at the Broad Ripple Dam by impounding the flow in Cicero Creek 20 miles upstream for release during periods of low flow.

The average flow in Fall Creek is about $175 \mathrm{mgd}$, but the minimum daily flow is about $5 \mathrm{mgd}$. The Indianapolis Water Co. has increased the dependable flow to about $25 \mathrm{mgd}$ by storage in Geist Reservoir. Eagle Creek has an average flow of about $94 \mathrm{mgd}$ but has been dry during drought periods. Substantial storage facilities would be required to provide a significant firm supply. Other minor tributaries have insignificant flows and small potential even with storage facilities.

The total average flow of the White River and its tributaries is about $1,000 \mathrm{mgd}$ at Indianapolis, of which about 6 percent, or $60 \mathrm{mgd}$, is being used for municipal supply. Since the dependable supply in periods of drought is a'jout $50 \mathrm{mgd}$, it is obvious that storage facilities are required to utilize a substantial part of the potential supply. Good reservoir sites are not abundant in the till plain of the White River basin. The future development of large quantities of dependable flow and a substantial part of the potential is dependent to a large extent upon the availability of good reservoir sites.

\section{Ground Water}

It is difficult to determine the potential ground-water supply available to the Indianapolis area. This difficulty is due to widespread variation in the origin and physical character of the water-bearing materials, and also to a deficiency in specific hydrologic and hydraulic data on these materials. The quantity of ground water believed to be perennially available has been computed indirectly using available hydrologic data and is about $235 \mathrm{mgd}$ for the area. The use of ground water is about $60 \mathrm{mgd}$ or about 25 percent of the calculated total available. The amount of ground water used during the period of greatest industrial expansion and heaviest demands, the war years $1943-45$, is not known. Estimates have been made and indicate that the total use reached a peak of 77 to $80 \mathrm{mgd}$ or about 30 percent of the total available. These large quantities of water were taken from storage in the vast underground reservoirs of the area, and in the areas of concentrated heavy withdrawals the water levels declined rapidly. It should be pointed out that during this war period a drought occurred. Since the war years withdrawals have been relaxed, there have been several years of better than normal precipitation to replenish the underground reservoirs, and in general water levels have returned to prewar positions, thus increasing the total available ground water in storage.

The industrial use of ground water has remained about constant even though the per capita consumption has increased where ground water is used for public supply and industrial uses. The reason is that commercial establishments, small industries, and certain other industrial water requirements are being supplied with water through purchase from the public water- 
supply systems. This trend has affected the use of ground water, especially in the downtown Indianapolis area. However, this trend could reverse rapidly with more widespread acceptance and application of improved techniques of well development and testing and conservation of ground water. Recirculation of water used by industries and return of substantial amounts of water to aquifers would do away with waste of large quantities to the sewers. It is possible, therefore, to increase the overall use of ground water. In areas of heavy pumping safe increases are possible provided artificial recharge is practiced and certain controls exercised. Economic considerations will be the greatest factor in determining whether the use of ground water will increase or decrease in the future.

Favorable areas for increased ground-water development are the alluvium and terrace deposits along the White River and parts of the alluvium fill of the Fall Creek and Eagle Creek valleys. Large quantities of water can be obtained from wells by means of induced infiltration from the streams; for example, a large-diameter collector-type well in Indianapolis obtains as much as 6,000 gpm from the permeable alluvial fill of the White River. Wells of other types adjacent to streams show relatively high yields and comparatively small drawdowns. Many of these wells are undoubtedly being heavily recharged from the streams.

Other areas of potentially large ground-water development are believed to be the buried valley sections in the extreme northeastern and eastern parts of Marion County. These areas have not been thoroughly tested and evaluated. It is possible that the several apparent water-bearing horizons will not be capable of supplying large quantities throughout the entire extent of these buried deposits. The data on the character of these water-bearing materials are still very meager.

The water-supply potentialities of the till that underlies the major portion of the eastern, northern, and western parts of the Indianapolis area are very erratic. Although exceptional yields have been obtained from some drilled wells these seem to be the exception rather than the rule. The records show that these wells have been more carefully constructed and developed than most other wells. In general, wells in aquifers associated with till are not considered as reliable producers of large quantities of water.

There seems to be little development of the sand and gravel horizons in the glacial drift of the southern part of Marion County. In some places the sands are very fine grained but according to driller's reports contain an abundance of water. Most driliers case these fine sands off because they are not experienced or equipped to develop such aquifers. An extensive boulder belt crosses this area. Although it is troublesome to drillers, successful wells have been drilled where the belt contains large amounts of gravel instead of clay mixed with boulders.

Along the western edge of Marion County groundwater potentialities seem to be small. This is the area of thin clayey till of low permeability beneath which is found the New Albany shale and the siltstones and shales of the Borden group, all the consolidated rocks being of low permeability. The water is usually highly mineralized and often contains iron in sufficient quantities to make it objectionable.
The ground-water potential of the bedrock aquifers is very important. Bedrock generally yields small quantities of water to wells and, where use demands large amounts of water, water must be obtained by continuous pumping and storage, or obtained from several wells. The upper limestones of the area are considered good water sources. Water levels and yields of wells in these limestones show that much water has been taken from storage. However, in some places substantial quantities of water have been pumped for long periods of time. In some places the shales yield small amounts of water of poor quality from open crevices.

Moderate to large supplies of highly mineralized water are available from deeper rock aquifers below the Niagaran limestone of drillers. This water must be treated before it can be used for most purposes. How ever, these sources should not be rejected as a potential supply. Conservation will delay the time when it will become necessary to develop these sources of highly mineralized water, but eventually they may be useful.

\section{WATER LAWS}

\section{Surface Water}

In Indiana the doctrine of common-law riparian rights is recognized for surface waters.

State laws with respect to pollution of surface waters have been enacted by the General Assembly. The Act of 1919 , Chapter 60 , created the Department of Conservation and under Section 18 a Division of Lands and Waters was established. The Act of 1929, Chapter 193, amended Section 18. Investigation of lakes, streams and springs for purposes of protection against impurities or pollution by industrial, municipal, or other sewage wastes is covered in paragraph 8 . General charge and supervision of navigable waters is stated in paragraph 9 .

In 1935 the first stream pollution law was enacted. The Act of 1943, Chapter 214, of the General Assembly created a new Stream Pollution Control Board and repealed the earlier Act of 1935, Chapter 152. The membership of this board was changed by the Acts of 1945 , Chapter 132, that amended sections 2 and 3 of Chapter 214 , Act of 1943 .

\section{Ground Water}

Common-law riparian rights applied to ground water until 1948. The Acts of 1947 of the General Assembly, Chapter 154, placed certain restrictions on the use of ground water for air conditioning and cooling effective January 1, 1948. This law was not enforced strictly and was repealed by the Act of 1951, Chapter 29. Under the new law the Department of Conservation is authorized to declare "restricted use areas" where withdrawals exceed or threaten to exceed replenishment, or to refuse permits for new uses exceeding $100,000 \mathrm{gpd}$ and to prohibit waste of ground water in restricted use areas.

Under the Oil and Gas Law Acts of 1947, Chapter 277, and Acts of 1951, Chapter 137, the Department of Conservation regulates the disposal of salt water and waste 
liquids produced in the operation of oil and gas wells to prevent surface and underground contamination.

\section{SELECTED BIBLIOGRAPHY}

Allen, Claris, 1945, Design and construction of Geist Reservoir: Am. Water Works Assoc. Jour., v. 37, no. 12 .

Brown, E. A., 1949, Ground-water resources of Boone County, Ind.: Ind. Div. of Water Res. Bull. 4.

Brown, R. T., 1882, Report of a geological and topographical survey of Marion County, Ind.: Ind. Dept. Geology and Nat. History, 12th ann. rept.

Buehler, E., 1908, Private wells and public water supply of Indianapolis: Ind. Sanitary and Water Supply Assoc. Proc.

Capps, S. R., 1910, The underground waters of northcentral Indiana, with a chapter on the chemical character of the waters by R. B. Dole: U. S. Geol. Survey Water-Supply Paper 254.

Clapp, F. G., 1908, Underground water supply of Indiana: Ind. Sanitary and Water Supply Assoc. Proc.

Dryer, C. R., 1918, The physiography of Indianapolis: Ind. Acad. Sci. Proc. 1917.

Geib, W. J., and Schroeder, F. C., 1911, Soil survey of Marion County, Ind.: Ind. Dept. Geology and Nat. Res., 36th ann. rept.

Gorby, S. S., 1888, Natural gas and petroleum: Ind. Dept. Geology and Nat. History, 16th ann. rept.

Harrell, Marshall, 1935, Ground water in Indiana: Ind. Div. Geol. Pub. 133.

Hurty, J. N., 1908, History of water supply in Indiana: Ind. Sanitary and Water Supply Assoc. Proc.

Indiana Department of Conservation, 1928, Surfacewater supply of Indiana: Pub. 72. Pub. 112 .

Indiana Geological Survey, 1952, Base map of Marion County, Ind.: Base map no. 49.

Indiana State Chamber of Commerce, 1954, Indiana industrial directory 1954-55: 8th ed.

Indianapolis Water Company, 1953, Annual report of 1952.
Leverett, Frank, 1897, The water resources of Indiana and Ohio: U. S. Geol. Survey 18 th ann. rept., pt. 4.

1899, Wells of southern Indiana: U. S. Geol. Survey Water-Supply Paper 26.

Leverett, Frank, and Taylor, F. B., 1915, The Pleistocene of Indiana and Michigan and the history of the Great Lakes: U. S. Geol. Survey Mon. 53.

Logan, W. N., 1922, Economic geology of Indiana in Handbook of Indiana Geology, pt. 5: Ind. Dept. Conserv. Pub. 21, p. 937-939.

1931, The sub-surface strata of Indiana: Ind. Dept. Conserv. Pub. 108.

Malott, C. A., 1922, Physiography of Indiana in Handbook of Indiana Geology, pt. 2: Ind. Dept. Conserv. Pub. 21, p. 204-212.

McGuinness, C. L., 1943, Ground-water resources of the Indianapolis area, Marion County, Ind.: Ind. Dept. of Conserv.

Meinzer, O. E., 1923, The occurrence of ground water in the United States with a discussion of principles: U. S. Geol. Survey Water-Supply Paper 489. 1923 , Outline of ground-water hydrology, with definitions: U. S. Geol. Survey Water-Supply Paper 494.

Perry, J. I., Mitchell, M. L., and McGrain, Preston, 1951, Indiana's water resources: Ind. Flood Control and Water Res. Comm. Bull. 1.

United States Geological Survey, issued annually, Surface-water supply of the United States, part 3, Ohio River Basin: U. S. Geol. Survey Water-Supply Papers.

United States Weather Bureau, issued annually, Daily river stages at principal rivers of the United States. 1951, Local climatological summary with comparative data, Indianapolis, Ind.

\section{Unpublished Reports}

United States Corps of Engineers, Louisville Dist., 1944, Survey report for flood control, Wabash River and tributaries, Indiana and Illinois (mimeographed). 
.

' 